\title{
Methods in cell biology ${ }^{\star}$
}

\section{Shai Shaham ${ }^{\S}$, ed., The Rockefeller University, New York, NY 10021, USA}

\section{Table of Contents}

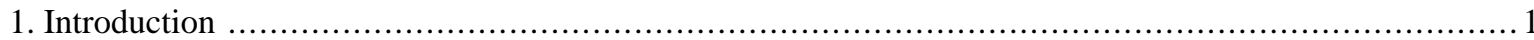

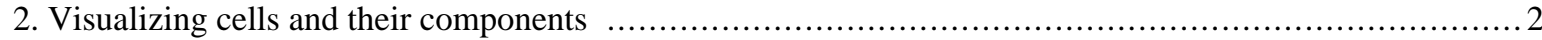

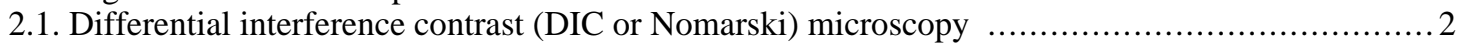

2.2. Polarized light microscopy (Denise Flaherty and Guy Benian) …................................... 4

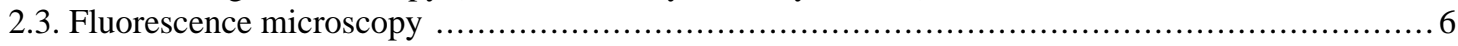

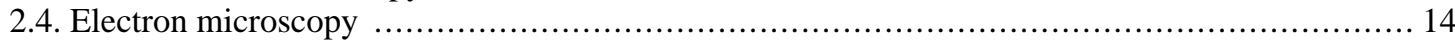

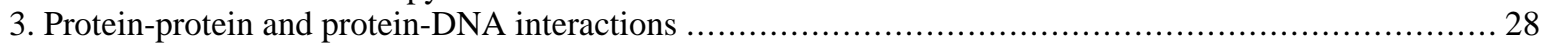

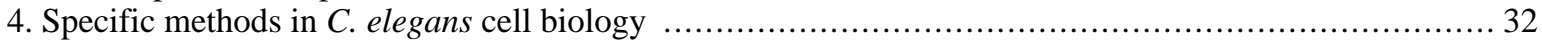

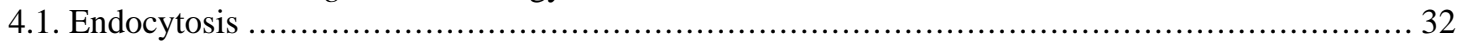

4.2. Chromatin cell biology (Györgyi Csankovszki and Barbara Meyer) ............................. 35

4.3. Programmed cell death (Barbara Conradt, Julia Hatzold, Claus Schertl) ............................. 43

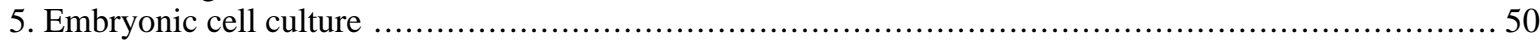

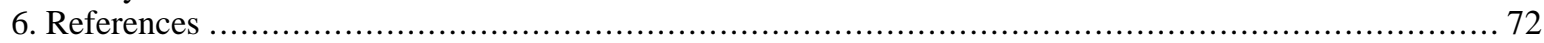

\section{Introduction}

Although C. elegans is primarily touted for its facile genetics, there has been a burgeoning interest in studying cell biological processes in this organism. Strong genetics (Brenner, 1974; Jorgensen and Mango, 2002), the development of fluorescent protein tags (Chalfie et al., 1994; Yang et al., 1996; Zhang et al., 2004), the availability of RNA interference strategies to disrupt gene function (Fire et al., 1998; Timmons and Fire, 1998), and the ability to perform studies on primary cultures of embryonic cells (Christensen et al., 2002; Zhang et al., 2002), have all led to an increase in the number of cell biological problems addressed in the worm. Furthermore, the transparency of the organism affords a unique opportunity to study the roles of cell biological processes in a living multicellular animal.

A serious obstacle to studying cell biological phenomena in C. elegans is the small size of its cells. However, advances in imaging techniques have allowed faint signals to be significantly amplified, and small structures to be visualized, allowing examination of transport, export, and import processes, as well as examination of cytoskeletal and chromatin structure.

\footnotetext{
*Edited by Victor Ambros. Last revised August 12, 2005. Published January 02, 2006. This chapter should be cited as: Shaham, S., ed., WormBook: Methods in Cell Biology (January 02, 2006), WormBook, ed. The C. elegans Research Community, WormBook, doi/10.1895/wormbook.1.49.1, http://www.wormbook.org.

Copyright: (C) 2006 Shai Shaham and contributors. This is an open-access article distributed under the terms of the Creative Commons Attribution License, which permits unrestricted use, distribution, and reproduction in any medium, provided the original author and source are credited.

${ }^{\S}$ To whom correspondence should be addressed. E-mail: shaham@ rockefeller.edu
} 
Here we have compiled a set of protocols that broadly fit under the category of Cell Biology. We begin with a brief discussion of various microscopical techniques employed by $C$. elegans researchers to study aspects of the cell. We then describe methods for studying protein-protein and protein-DNA interactions in C. elegans. We also describe methods used to study specific cell biological problems (e.g. endocytosis, chromatin, programmed cell death). Finally, we conclude this chapter with a discussion of primary embryonic cell culture and its uses.

Contributors of sections or protocols are acknowledged in parentheses following the section or protocol titles. In some cases, protocols are based on previously published work, which is then cited after the protocol title. The on-line format of this chapter should easily allow for revisions and additions to the protocols presented here. Researchers willing to share protocols not presented here or with comments on existing protocols are encouraged to submit these to shaham@rockefeller.edu.

\section{Visualizing cells and their components}

To study objects we must interact with them. Generally, the technique of interaction is determined by the size of the object. Thus, an object of macroscopic size can be studied by direct contact. However, microscopic objects, such as the cell and its organelles, must be studied with agents of similar or smaller size. Cells in $C$. elegans are roughly 3-30 microns in diameter, thus, light with wavelength in the visible range $(\sim 500 \mathrm{~nm})$ is an ideal interacting agent. The set up of light microscopes affords a resolution that is about half the wavelength of light employed. Thus, light microscopy is useful for examining cells and cellular substructures on the order of 200-300 nm or larger. However, vesicles (often $50 \mathrm{~nm}$ in diameter), and other objects of similar or smaller scale cannot be resolved using current setups. Although, in principle, light of very short wavelength (e.g. X-rays) could be used to resolve smaller cellular structures, such light is too energetic, damaging the cell upon contact. In addition, lenses to focus high energy photons do not exist. High resolution can be obtained using electron microscopy. Moving electrons in an electron microscope possess wavelengths on the order of $0.3 \mathrm{~nm}$. Using an electron microscope, the electrons can be used to form resolved images of cellular structures of about $3 \mathrm{~nm}$ in size.

\subsection{Differential interference contrast (DIC or Nomarski) microscopy}

Visible light can be used to examine C. elegans, however, in general, bright field and phase-contrast microscopy offers little contrast- making cells and their major components difficult to see. DIC microscopy, however, allows high contrast images to be formed, and is ideal for examining nuclei, nucleoli, and granular structures within C. elegans cells (Sulston and Horvitz, 1977; Sulston et al., 1983). In DIC microscopy light passes through a plane polarizer. The resulting polarized light is split into two components using a prism. These components interact with the sample, and are combined above the objective using a second prism. Finally, the transmitted light passes through an analyzer (essentially a polarizer that is polarized at 90 degrees with respect to the original plane of polarization) and on to the observer. The interaction of polarized light with the sample changes its plane of polarization. Thus, only light whose polarization is changed by the sample will be detected by the observer. In this way, highly contrasted images are formed. It should be remembered that shadowing effects seen using DIC microscopy do not reflect three-dimensional features of the sample. Rather, they reflect the ability of the specimen to interact with polarized light. Current microscopes allow the use of a 100X objective with DIC, giving high magnification and resolution. Some microscopes are equipped with additional lenses, however, these do not afford better resolution.

A protocol for mounting C. elegans for observation using DIC microscopy is presented below. This protocol can be used to mount animals for all microscopic techniques utilizing a compound microscope.

\section{Protocol 1: Mounting animals for observation with DIC optics (Monica Driscoll)}

\section{Preparation of Agar Pads:}

$\underline{\text { a. Materials }}$

- $5 \%$ agar solution in water, melted and kept molten by placing the tube in a heat block at $65^{\circ} \mathrm{C}$

- $\quad$ Pasteur pipette and bulb 
- 2 glass slides with pieces of labeling tape (for example, Fisher \#11-880-5-D) taped over both ends to serve as spacers

- 2 clean glass slides

b. Preparation of Pads (See Figure 1):

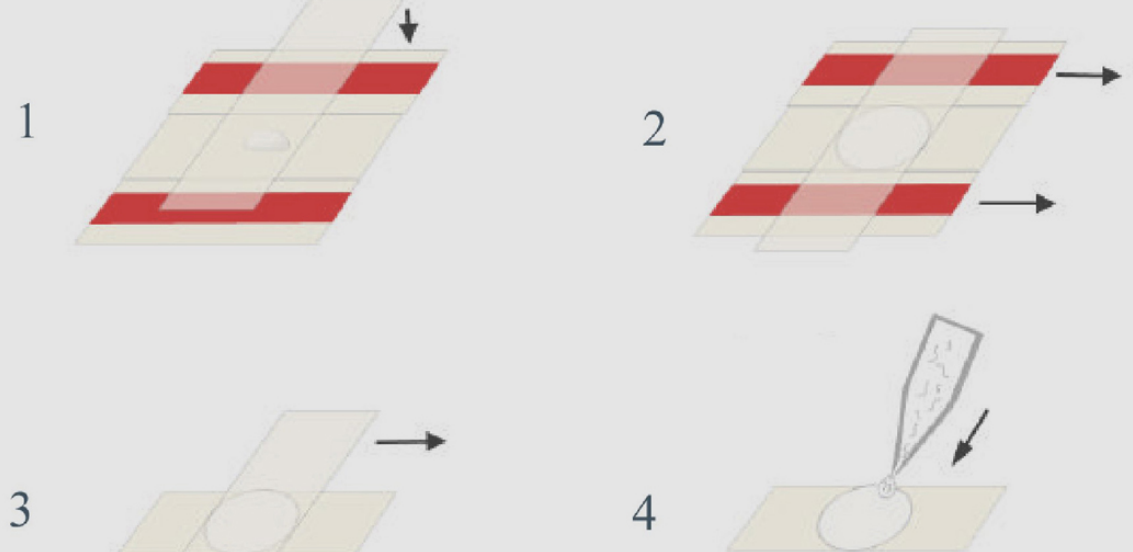

Figure 1. Preparing agar pads (Monica Driscoll).

Place the two taped slides with a clean slide sandwiched between them on a flat surface. Using the Pasteur pipette, place a drop of agar onto the clean slide. Cover the agar with another clean slide placed on top of the three slides in a perpendicular fashion. Press gently so the agar drop is flattened to a circle about $0.4 \mathrm{~mm}$ thick (the thickness of the tape spacers). Avoid getting bubbles in the agar since worms will get stuck in them. After the agar solidifies, gently pull out the taped slides, then separate the remaining two slides by sliding one relative to the other. The agar pad should adhere to one of the slides (usually the bottom one). Rest the slide, agar side up, on the bench top.

Note: The agar pad should be prepared just before use so that it does not dry out. Alternatively, once you pull out the taped slides, you can wrap the cross shaped slide-agar-slide in a piece of Saran wrap. This way you can keep the pad moist for a couple of hours.

\section{Mounting Live Animals:}

Place a 1-2 ul drop of M9 containing $10-25 \mathrm{mM}$ sodium azide $\left(\mathrm{NaN}_{3}\right)$ onto the center of the agar pad. $\mathrm{NaN}_{3}$ anesthetizes the worms so that they will not move. The agar pad can also be prepared with anaesthetic included for a final concentration of $2-10 \mathrm{mM} \mathrm{NaN}$ in the agar, instead of in the drop. This generally results in faster anesthetic action. If live worms are needed, $\mathrm{NaN}_{3}$ can be omitted and bacteria can be added to the drop to allow the worms to feed with little motion.

Transfer animals to be observed into the drop. Animals can be transferred using a worm pick or an eyebrow hair fastened to a toothpick with wood glue or clear nail polish. When the hair or pick is moved into the drop, animals float off easily. Alternatively, animals can be spun down in M9 in an eppendorf tube at 1200-1500 rpm with slow acceleration/deceleration. After the supernatant is discarded, the animals are suspended in $10 \mathrm{ul} \mathrm{M} 9-\mathrm{NaN}_{3}$. $2-3$ ul of the solution with the animals can then be transferred to the pad. 
Gently lay a coverslip over the animals. Most animals will lie on their left or right sides. Embryos also generally assume stereotypic orientations on agar pads. Between the 4-cell stage and 100-150 minutes the embryos display either the left or right sides. At gastrulation $(150 \mathrm{~min})$ they turn from left to dorsal or from right to ventral. At 350-400 minutes they return to display left or right sides (Sulston et al., 1983).

Animals will stop moving within a minute or two. Animals in sodium azide can recover following incubation in sodium azide of one-hour or less.

\subsection{Polarized light microscopy (Denise Flaherty and Guy Benian)}

Polarized light can be used to examine repeated or crystalline structures. In a manner similar to DIC, plane polarized light that passes through a specimen will interact with the specimen and change its plane of polarization, allowing light to be detected through an analyzer located above the specimen and oriented at 90 degrees to the initial plane of polarization (for a more complete description see http://www.microscopyu.com/articles/polarized/ polarizedintro.html).

The muscles used for locomotion in C. elegans reside in the body wall. In the adult, there are 95 spindle shaped cells divided among four quadrants just underlying a basement membrane, hypodermis and cuticle. In each quadrant, the cells are arranged in interlocking pairs. In these muscle cells, myofilaments form a lattice that is restricted to a narrow zone of $\sim 1.5$ microns, just underlying the basement membrane and hypodermis. By polarized light microscopy, obvious striations are seen; bright ("birefringent") A-bands alternate with dark I-bands; each I-band contains a row of dense bodies, which are the analogs of Z-discs of vertebrate striated muscle (Figure 2). Because the striations lie at a slightly oblique angle with respect to the long axis of the worm, this muscle is called "obliquely striated". Polarized light is also useful for evaluating the second largest set of muscles, those in the pharynx. Below we present a protocol for observing $C$. elegans muscle using polarized light.

\section{Protocol 2: Observing C. elegans muscle using polarized light (Denise Flaherty and Guy Benian)}

\section{Materials and Equipment}

1. Healthy worms

2. Light microscope (not inverted) with:

- light source

- strain free objectives

- condenser appropriate for bright-field and differential interference contrast microscopy (often labeled H/DIC)

- an analyzer slider

- A rotating stage. This would not be necessary if worms had an obliging habit of lying down on the slide, stick straight, at a $45^{\circ}$ angle within the field of view.

\section{$\underline{\text { Method }}$}

Pick one to several adult animals onto a clean glass slide (avoid dust) containing an 18ul drop of M9 buffer. Take care to pick up as little bacteria as possible, as it could obscure the view. It is also often customary to add sodium azide to a final concentration of $20 \mathrm{mM}$ in order to slow the movement of the animal for imaging.

Next, cover the animal with a number 1 coverglass, 22 by $40 \mathrm{~mm}$, and view the animal under the microscope using the following procedure:

1. Be sure that the analyzer slider is in place 
2. Set the index of the condenser to "H/DIC"

3. Move any color or gray filters out of the way

4. For microscopes with a rotating polarizer, set the rotating polarizer lever on the condenser to $0^{\circ}$.

5. Find the animal on the slide using a low power objective such as $10 \mathrm{X}$.

6. Once the animal has been found, place it in the center of the field of view.

7. Carefully move up to a higher magnification objective such as $40 \mathrm{X}$.

8. Get the animal into focus then close down the luminous field diaphragm so that the edges of the opening are in the field of view.

9. Change the height of the condenser until the edges of the opening are in crisp focus. Then use the condenser centering screws to center the opening in the field of view.

10. Open the luminous field diaphragm wide enough so that the edges go just beyond the field of view.

11. Rotate the stage until the muscle striations are most clearly seen. (This occurs when the striations are at a $45^{\circ}$ angle with respect to the field of view).

12. Change the level of light in the field by using the light source dial and/or the condenser diaphragm.

\section{$\underline{\text { Notes }}$}

1. getting the right "balance" of light is the key to successful polarized light microscopy. As the light from the light source is increased and the light coming through the condenser is decreased, stronger contrast will be achieved. Sometimes this contrast is too sharp, making the muscle look "grainy". If this is the case, begin to reduce the light from the light source and increase the light coming through the condenser. If this is done too much, there will not be enough contrast. Tweak each source of light carefully until the desired polarized light is achieved.

2. Worms that are healthy adults without many developing embryos are the best for polarized light microscopy due to the interference of these embryos over a quadrant of body wall muscle. Similarly, when a quadrant of body wall muscle happens to lie over the reflected arm of the gonad, this is advantageous, since the gonad acts as an empty window through which the muscle can be seen. Skilled practitioners of polarized light microscopy are able to gently roll the worm under the coverslip in order to achieve this effect. 

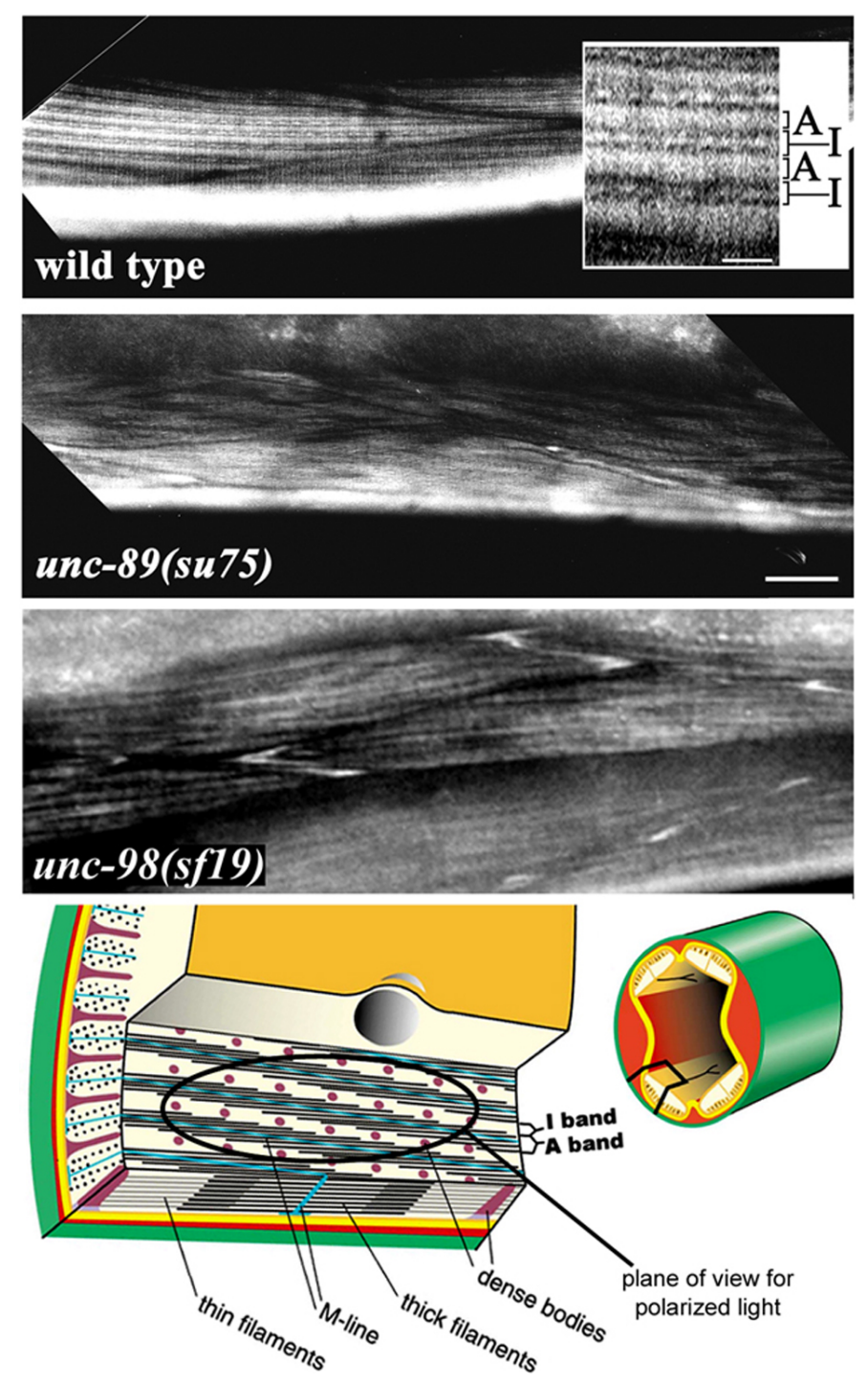

Figure 2. The top three panels show polarized light microscopy of adult body wall muscle from wild type and from two muscle-affecting mutants. Each image was captured with a $40 \mathrm{X}$ objective and shows portions of about three muscle cells. The inset shows an enlarged view. Wild type muscle shows a high degree of organization with birefringent A-bands alternating with dark I-bands, each containing a row of dense bodies. unc-89(su75) exhibits the phenotype of a typical unc-89 mutant: reduced organization of the myofilament lattice with an almost "basketweave" pattern. unc-98(sf19) displays disorganized myofibrils with characteristic birefringent "needles" at the ends of the muscle cells. The bottom panel is an illustration showing the position of the four muscle quadrants (right) and a portion of a single muscle cell emphasizing the myofilament lattice. The oval indicates the plane of view seen by polarized light (Denise Flaherty and Guy Benian).

\subsection{Fluorescence microscopy}

\subsubsection{Fluorescent dyes}

Cellular structures and components can be labeled with a variety of fluorescent dyes that can be visualized using a fluorescence microscope. In response to incident light of specified wavelength (produced by a laser or using appropriate filters), fluorescent dye molecules are excited. Decay of the molecule from the excited state to an intermediate excited state produces a photon of a wavelength longer than that of the excitation source, which can easily be detected and separated, using appropriate filters, from the incident light (for a more detailed description see http://www.microscopyu.com/articles/fluorescence/fluorescenceintro.html). Below are a number of protocols for using dyes to visualize DNA, proteins and cellular structures. Dyes coupled to antibodies are particularly useful for visualizing the presence and localization of specific proteins within the cell, and several methods for antibody staining are discussed in the chapter on gene expression. Often it is of interest to study whether two cellular 
molecules physically interact. Fluorescence resonance energy transfer (FRET) has been used to indicate the proximity of two labeled fluorophores. However, this method has not been significantly used in C. elegans to date.

\subsubsection{Visualizing DNA}

A number of fluorescent dyes can be used to visualize DNA in fixed animals. 4',6'-diamidino-2-phenylindole hydrochloride (DAPI), is by far the most commonly used DNA dye in C. elegans (Figure 3).

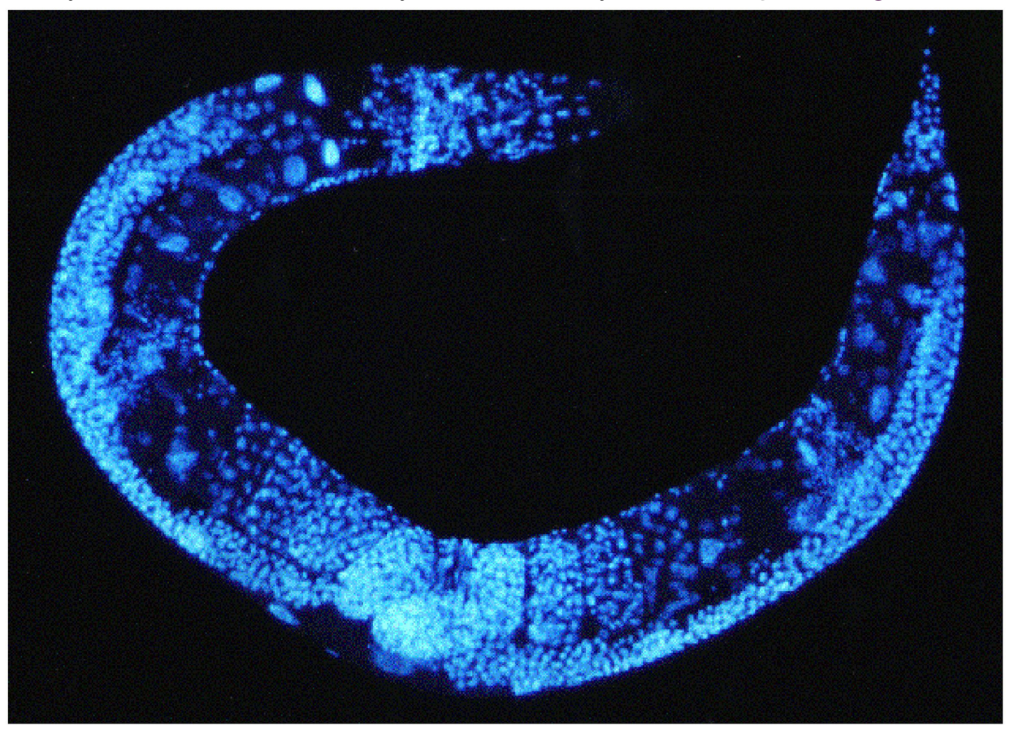

Figure 3. Adult hermaphrodite stained with DAPI (Jim McCarter and Tim Schedl).

\section{Protocol 3: Staining animals with 4',6'-diamidino-2-phenylindole hydrochloride (DAPI) to visualize DNA}

1. Animals are fixed by any of the methods used for antibody staining and left to incubate in a neutral buffer such as PBS or Tris-Triton.

2. To visualize the DNA, samples are incubated with $100 \mathrm{ng} / \mathrm{ml}$ of DAPI in the neutral buffer of incubation for about 30 minutes. Samples are washed $3 \mathrm{X}$ in buffer, and mounted for observation either on an agar pad or directly onto glass slides and covered with a cover slip.

3. DAPI is excited by UV light $(310 \mathrm{~nm})$ and emits fluorescence light in a broad peak centered around $430 \mathrm{~nm}$.

\subsubsection{Labeling exposed neurons with dyes}

Amphid and phasmid neurons can take up lipophilic dyes from the environment (Hedgecock et al., 1985; Perkins et al., 1986). These dyes will label all parts of the neuron. The mechanism of dye uptake is unclear, but seems to correlate with some aspect of neuronal function. Thus, these dyes can be used to visualize neurons and perhaps to study their physiology (Figure 4). The dye fluorescein isothiocyanate (FITC) can be used to label the ADF, ASH, ASI, ASJ, ASK, and ADL cells of the amphid sensilla, and the PHA and PHB neurons of the phasmid sensillum. DiI, DiO, and DiD (Molecular Probes) can be used to visualize the ASI, ADL, ASK, AWB, ASH, and ASJ amphid neurons, as well as the PHA and PHB phasmid neurons (Collet et al., 1998). 


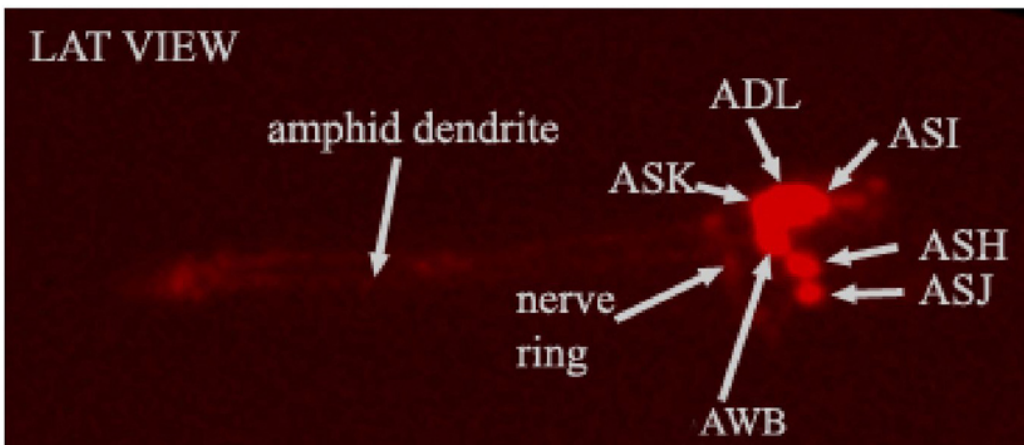

DiI staining of amphids

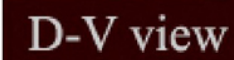

\section{DiI staining of phasmids}

Figure 4. DiI staining of amphid (top) and phasmid (bottom) neurons (Zeynep Altun and Dave Hall).

\section{Protocol 4: Staining amphid and phasmid neurons using FITC (based on Hedgecock et al., 1985)}

A stock dye solution containing $20 \mathrm{mg} / \mathrm{ml} 5$-fluorescein isothiocyanate (FITC) in dimethyl formamide can be stored at $-20^{\circ} \mathrm{C}$ indefinitely.

$50 \mathrm{ul}$ of stock solution is mixed with $200 \mathrm{ul}$ of M9 buffer and applied evenly to the surface of a $10 \mathrm{ml}$ NGM plate preseeded with a lawn of $E$. coli. After two hours, to allow the dye to diffuse into the agar (final concentration $0.1 \mathrm{mg} / \mathrm{ml}$ ), live animals are transferred to the plate. After staining for 2 hours to overnight, the animals are transferred to a plate devoid of dye for at least 10 min to remove free FITC from the intestine.

Animals are mounted for observation as described for DIC microscopy. FITC excitation wavelength maximum: $494 \mathrm{~nm}$, emission wavelength maximum: $520 \mathrm{~nm}$.

\section{Protocol 5: Staining amphid and phasmid neurons using FITC, DiI, DiO, DiD}

A stock solution of $2 \mathrm{mg} / \mathrm{ml}$ FITC in dimethyl formamide is stored at $-20^{\circ}$ in a foil wrapped tube.

Dilute the stock 1:200 in M9. Some dye will precipitate when you do this; don't worry about it. Put $150 \mu 1$ stain in a microtiter well or eppendorf tube, and use a worm pick to transfer some worms into the dye. Alternatively, wash a plate of worms with M9, concentrate to about $50 \mu \mathrm{l}$ and add $100 \mu \mathrm{l}$ dye. Incubate 2-3 hours at room temperature. Wild-type animals will begin to take up dye within less than an hour. 
Transfer worms to a fresh plate, and let crawl on a bacterial lawn for about 1 hour to destain. Alternatively, wash the worms $3 \mathrm{X}$ in $\mathrm{M} 9$.

Animals are mounted for observation as described for DIC microscopy.

\subsubsection{Visualizing actin}

Filamentous actin can be readily observed in C. elegans muscle by staining with fluorescin-conjugated phalloidin (Strome, 1986). Other actin structures can also be visualized using this method, however, Protocol 7, below, should be used.

\section{Protocol 6: Phalloidin staining of F-actin (based on Strome, 1986)}

1. Rinse worms off a plate with $S$ basal, spin briefly in a clinical centrifuge, rinse once with more $S$ basal to remove bacteria.

2. Put $10 \mathrm{ul}$ of worms in an eppendorf tube, freeze in liquid nitrogen, then immediately place in a speedvac to lyophilize the worms (takes $\sim 5 \mathrm{~min}$ ). Add 3-4 drops ice cold acetone, wait $5 \mathrm{~min}$, remove as much of the acetone as possible and air dry the remaining acetone. Worms can be stored in this way prior to staining.

3. Put 2 U fluorescein-conjugated phalloidin (Molecular Probes) in an eppendorf tube. Speedvac off the methanol to dryness. Add $20 \mathrm{ul} \mathrm{"S} \mathrm{mix"} \mathrm{to} \mathrm{dissolve} \mathrm{the} \mathrm{phalloidin,} \mathrm{and} \mathrm{add} \mathrm{this} \mathrm{to} \mathrm{the} \mathrm{dry} \mathrm{worms.} \mathrm{Let} \mathrm{the} \mathrm{worms} \mathrm{stain} \mathrm{at}$ room temp (in the dark to prevent bleaching) for $0.5-1$ hour.

4. Wash the worms $2 \mathrm{X}$ in $1 \mathrm{ml}$ of PBBT (PBS $+0.5 \% \mathrm{BSA}+0.5 \%$ Tween-20).

5. Resuspend the worms in $20 \mathrm{ul}$ of $2 \mathrm{ug} / \mathrm{ml}$ DAPI in PBS (DAPI is kept frozen as a $1 \mathrm{mg} / \mathrm{ml}$ stock). Let the worms sit $>5$ min.

6. For viewing, mix a few ul of worm suspension with an equal volume of mounting solution ( $90 \%$ glycerol, $10 \%$ PBS, $1 \mathrm{mg} / \mathrm{ml}$ phenlyenediamine).

7. Viewing: illuminating for DAPI fluorescence bleaches the FITC rapidly, so be careful.

\section{$\underline{\mathrm{S} \operatorname{mix}}(1 \mathrm{ml})$}

$743 \mathrm{ul} \mathrm{dH20,} 250 \mathrm{ul} 0.8 \mathrm{M}$ Na phosphate pH 7.5 (recipe: $8.1 \mathrm{ml} \mathrm{1M} \mathrm{Na} \mathrm{HPO}_{4}, 1.9 \mathrm{ml} \mathrm{1M} \mathrm{NaH} \mathrm{PO}_{4}, 2.5 \mathrm{ml}$ $\left.\mathrm{H}_{2} 0\right), 1$ ul $1 \mathrm{M} \mathrm{MgCl} 2,4$ ul $1 \%$ SDS

\section{Protocol 7: Phalloidin staining of F-actin in embryos (Vida Praitis, based on Costa et al., 1997)}

1. Grow up worms to gravid adult stage on high density or NGM plates. Wash off worms with M9. Add $10 \mathrm{ml}$ M9 to the plates and use a rubber policeman to gently dislodge the eggs from the plates. Pipette eggs into $15 \mathrm{ml}$ tubes. If you want earlier stage eggs, save adults and bleach, but this is not necessary for morphogenesis-stage embryos and the bleach can interfere with staining.

2. Pellet eggs. Resuspend in $\sim 10 \mathrm{ml}$ M9 with $0.01 \%$ Tween 20 . Remove supernatant. Repeat for 3 washes total. (The eggs are very sticky, so include tween or another mild detergent in the M9 to prevent them from sticking to the sides of the tube). Resuspend in $2 \mathrm{ml}$ culture media.

3. Pull up sample with $21 \mathrm{~g}$ needle in $3 \mathrm{ml}$ syringe. Push out with a $30 \mathrm{~g}$ needle. Repeat for total $3 \mathrm{X}$. 
4. Wash $1 \mathrm{X}$ with $1 \mathrm{ml} 1 \mathrm{X}$ ES/Hepes (no tween). Transfer to a siliconized $1.5 \mathrm{ml}$ eppendorf tube. (The siliconized tube coating helps prevent eggs from sticking; siliconized tubes can be purchased or made by dipping tubes in $2 \%$ dimethyldichlorosilane in 1,1,1-trichloroethane and drying).

5. Pull off supernatant to $120 \mu \mathrm{l}$. Add a small amount of Chitinase. Incubate $\sim 10$ minutes. Watch eggs on coverslip. Tadpoles should hatch out of eggshells.

6. Add $680 \mu \mathrm{l}$ of FIX 1 directly to egg sample. Incubate 2 minutes. Spin for $30 \mathrm{~s}$ in small microfuge.

7. Remove Fix 1 and add $1000 \mu \mathrm{l}$ of FIX 2. Incubate $15-20$ minutes. Wash $3 \mathrm{X}$ with $1 \mathrm{ml}$ culture media. Let eggs settle after 3rd wash. Remove supernatant.

8. Dry a $10 \mu \mathrm{l}$ sample of Alexa-Phalloidin in the dark (molecular probes). Resuspend Alexa -Phalloidin in $300 \mu \mathrm{l}$ of $1 \mathrm{X}$ PBS.

9. Add $300 \mu \mathrm{l}$ Alexa -Phalloidin in PBS to egg sample. Incubate 1 hour in dark.

10. Wash $3 \mathrm{X}$ with $1 \mathrm{ml}$ culture media.

11. Pull off supernatant to $\sim 30 \mu \mathrm{l}$. Add $30 \mu \mathrm{l}$ glycerol/anti-bleach. Mix. Spin.

12. Place $4 \mu \mathrm{l}$ of pellet/glycerol on slide. Add coverslip. Press very gently between paper towels to remove excess glycerol.

13. Seal coverslip with nail polish.

Reagents

\begin{tabular}{|l|c|}
\hline $4 \mathrm{X} \mathrm{Egg} \mathrm{Salts}$ & \\
\hline $472 \mathrm{mM} \mathrm{NaCl}$ & $5.517 \mathrm{~g}$ \\
\hline $160 \mathrm{mM} \mathrm{KCl}$ & $2.386 \mathrm{~g}$ \\
\hline $13.6 \mathrm{mM} \mathrm{CaCl} \cdot 2 \mathrm{H}_{2} 0$ & $0.400 \mathrm{~g}$ \\
\hline $13.6 \mathrm{mM} \mathrm{MgCl} \cdot 6 \mathrm{H}_{2} 0$ & $0.553 \mathrm{~g}$ \\
\hline $\mathrm{dH}_{2} \mathrm{O}$ & to $200 \mathrm{ml}$ \\
\hline
\end{tabular}

\section{$\underline{1 X \text { Culture Media }}$}

1X Egg Salts

$5 \mathrm{mM}$ Hepes, $\mathrm{pH} 7.2$

$5 \%$ Fetal Calf Serum

\section{FIX 1 (Make up fresh)}

\section{$0.60 \mathrm{ml} \mathrm{dH} 0$}

\section{$2.5 \mathrm{ml} 2 \mathrm{X}$ Eggs Salts/10 $\mathrm{mM}$ Hepes}

$0.1 \mathrm{ml} 0.5 \mathrm{M}$ EGTA

$1.0 \mathrm{ml} \mathrm{16 \%} \mathrm{Formaldehyde} \mathrm{(high} \mathrm{grade)} \mathrm{or} \mathrm{use} \mathrm{paraformaldehyde}$

$0.05 \mathrm{ml}$ 10 mg/ml Lysolecithin in PBS (L- $\mu$-Lysophosphatidylcholine Sigma \# L-4129)

$4.25 \mathrm{ml}$ Total Volume

FIX 2 (Make up fresh)

$1.4 \mathrm{ml} \mathrm{dH} 0$

$2.5 \mathrm{ml} 2 \mathrm{X}^{2}$ Eggs Salts/10 mM Hepes 
$0.1 \mathrm{ml} 0.5 \mathrm{M}$ EGTA

$1.0 \mathrm{ml} \mathrm{16 \%} \mathrm{Formaldehyde} \mathrm{(high} \mathrm{grade)}$

$5.0 \mathrm{ml}$ Total Volume

Anti-bleach

Available from molecular probes.

Alexa-Phalloidin

We buy this reagent from Molecular Probes. Alexa dyes produce a more intense signal and do not bleach as rapidly as fluorescein dyes.

Samples will eventually deteriorate (I've used it successfully for $>1$ year), so it is critical to date the reagents, and remember to check the date prior to use.

Siliconized Eppendorfs.

Chitinase Sigma \# C-6137

\subsubsection{Fluorescent proteins}

The use of fluorescent proteins to tag cellular proteins has revolutionized cell biology (Zhang et al., 2002). In C. elegans, green fluorescent protein (GFP) and its derivatives, and more recently DsRed, have been employed to visualize protein localization, movement, and conformational changes in vivo (Chalfie et al., 1994; Miyawaki, 2002). Fusions to any protein can be generated using sets of vectors constructed by Andy Fire and others (Miller et al., 1999). In addition, labeling of specific organelles can be accomplished using pre-made vectors containing GFP fused to specific subcellular targeting sequences. Localization signals that are frequently used include those for the nucleus, mitochondria, and plasma membrane. Details regarding fluorescent proteins can be found in the gene expression chapter.

\subsubsection{Fluorescently-labeled antibodies}

Examining protein localization using GFP or DsRed fusion proteins requires injection of corresponding transgenes into animals. Thus, a number of caveats exist in interpreting results from such experiments. For example, expression from transgene arrays is often higher than from the endogenous locus. Furthermore, fluorescent proteins are fairly bulky, thus, fusion proteins may not display appropriate localization. In addition, promoter elements used to drive expression of GFP transgenes are often expressed in cells where the endogenous protein is normally not made, or vice versa.

Fluorescently-labelled antibodies generated against a protein of choice allow direct examination of endogenous unmodified proteins, giving a clearer assessment of where endogenous expression is localized. Antibodies coupled to gold particles can also be used for electron microscopy to examine subcellular localization in great detail. Antibodies can only label fixed tissues, thus, they cannot be used for real time observation of protein localization dynamics. In addition, fixation often destroys cellular structure, limiting the resolution obtained by immunostaining. Detailed protocols for use of antibodies can be found in the gene expression chapter.

\subsubsection{Microscopy of fluorescently-labelled cells}

A number of microscopes are now commercially available for generating and examining fluorescent signals. All are able to resolve fluorescent entities both in space and in time. Differences among these microscopes center on spatial and temporal resolving power.

\subsubsection{Dissecting fluorescence microscope}

This binocular microscope allows visualization of highly expressed fluorescent signals at low magnification. The major use of the instrument is to visualize GFP and DsRed-labelled proteins in living worms on the surface of standard agar plates. Generally, use of this microscope allows selection of animals expressing a fusion protein of 
interest, as well as examination of very coarse cellular features (e.g. presence or absence of a neuronal process) for genetic screens (see for example Shaham and Bargmann, 2002). This method does not allow fine structure to be examined. The microscope consists of a standard binocular dissecting microscope equipped with epifluorescence.

\subsubsection{Compound fluorescent microscope}

This microscope has significantly higher resolution and magnification compared to the dissecting fluorescence microscope, and observation can be combined with DIC (Figure 5). Objectives of 100X are often used, and allow examination of gross subcellular localization of proteins. Images collected from such a microscope at high magnification suffer from an extensive background of fluorescent light emitted by cells not in the plane of focus and of scattered light. This often severely cuts down on the resolving power of this microscope. However, for first pass examination of samples, or for examining highly localized signals, this microscope is often the instrument of choice (for a more detailed description see http://www.microscopyu.com/articles/fluorescence/fluorescenceintro.html).
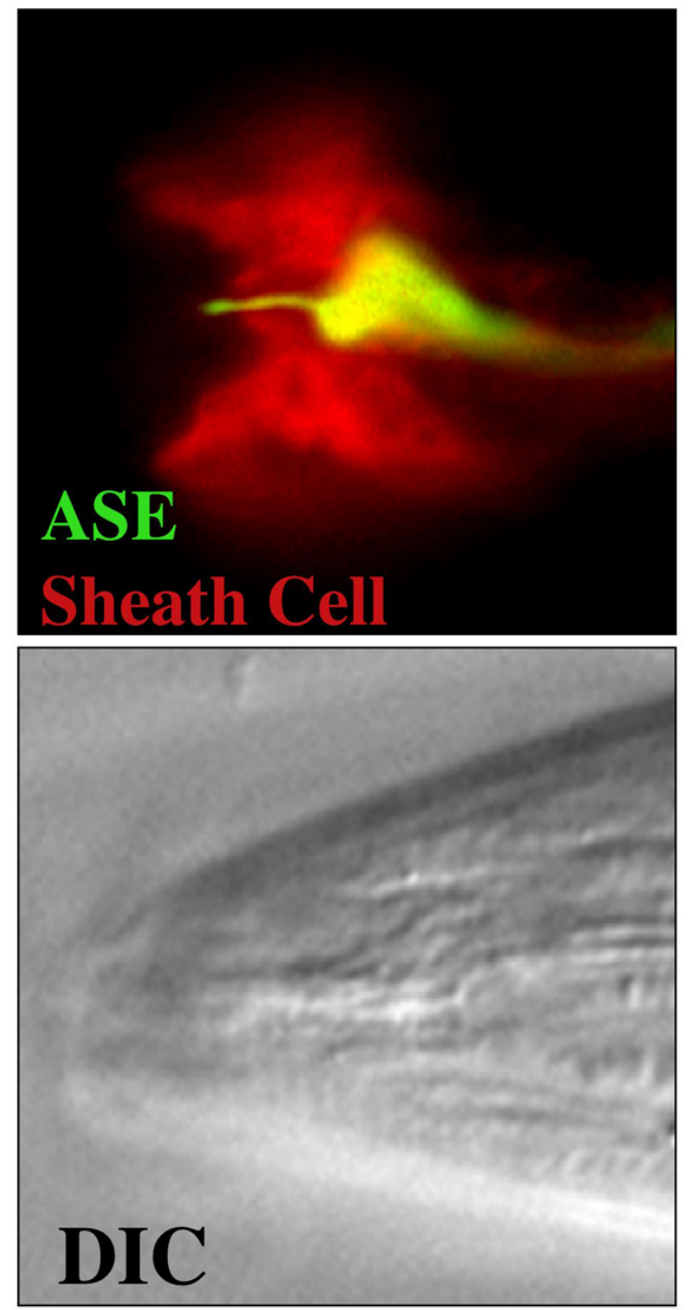

Figure 5. Standard fluorescence microscope image of the amphid ASE neuron and sheath cell (top). DIC view of same image (bottom) (Elliot Perens and Shai Shaham).

\subsubsection{Deconvolution fluorescent microscope}

This instrument is essentially a compound fluorescence microscope equipped with a sensitive light detection system. Light collected from optical sections through the sample is processed using sophisticated computer software, which assigns out-of-focus light to its correct focal plane (Wallace et al., 2001). Images generated by this microscope consist of optical sections through a sample, and allow 3-dimensional reconstruction of the fluorescent signal with little background. Sections can also be projected onto a single image, giving highly resolved artificial 
two-dimensional images (Figure 6). All images are viewed on a computer screen. Time-resolution of the technique is, in general, inversely proportional to spatial resolution. Thus, the more optical sections imaged, the larger the time intervals between image collections at any given focal plane. This type of microscope is not efficient for examining processes that occur over intervals of seconds or faster.

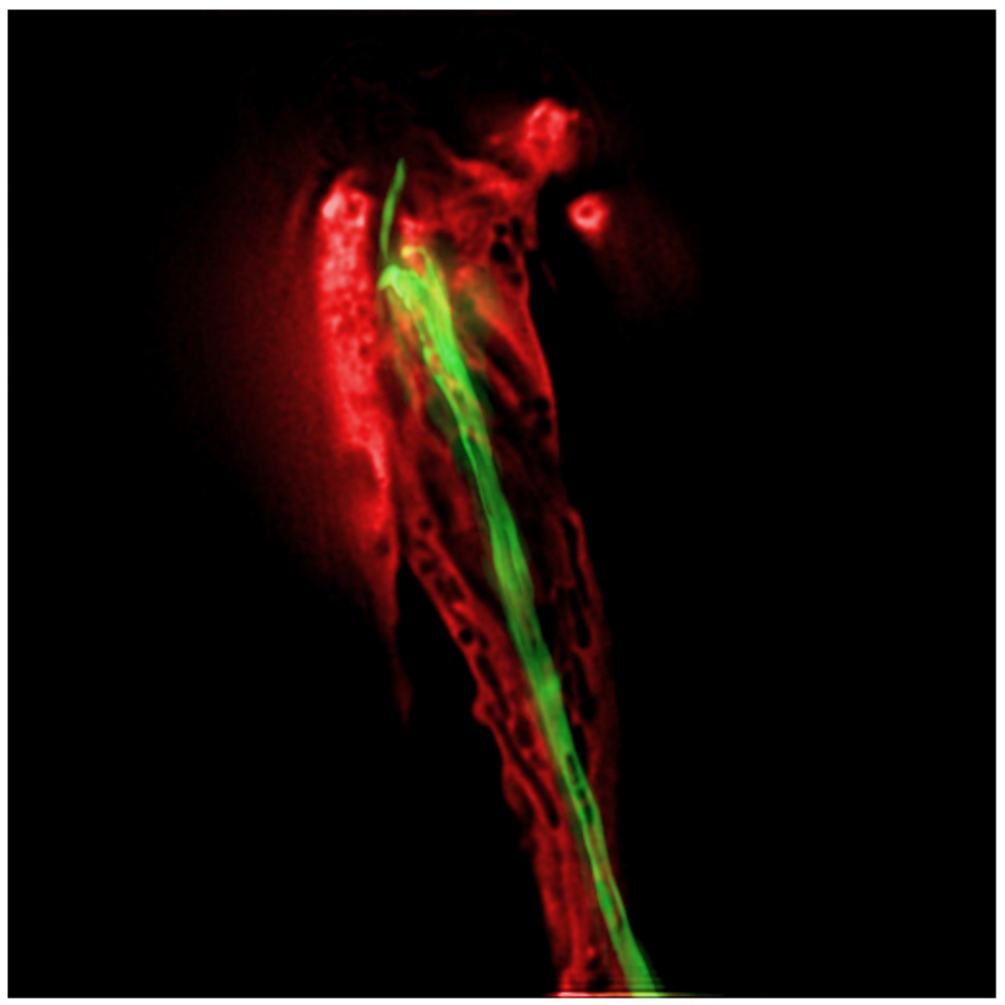

Figure 6. Deconvolution microscope image of amphid sheath cell (red) and ASE neuron (green) (Max Heiman and Shai Shaham).

\subsubsection{Laser scanning confocal microscope}

This instrument consists of a compound microscope equipped with a laser for fluorophore excitation, and a special detection set up consisting of a small pinhole through which emitted fluorescence light produced only near the focal plane of observation can pass. Light passing through the pinhole is collected in a sensitive light detector, and images are produced on a computer screen. This technique eliminates out-of-focus fluorescence, giving sharp images with little background (for more details see http://www.microscopyu.com/articles/confocal/). As with the deconvolution microscope, images consist of optical sections through the sample. Time-resolution of this microscopy is affected by several factors, including the time required for the laser to scan the field of view, and the amount of light that needs to be collected to visualize fluorescence. Unlike the deconvolution microscope, which uses all the light emitted by the sample to calculate the point of emission, a confocal microscope only collects light traveling through the pinhole, necessitating longer exposures or more sensitive light-detection systems.

\subsubsection{Spinning disc confocal microscope}

This instrument is a variation of the laser scanning confocal microscope. Here, many pinholes are arranged in a spiral pattern on a disc that can rotate at high speed. Thus, time resolution can be excellent (on the order of 100 msec or less), and photobleaching is generally not a significant issue as with other microscopes (Nakano, 2002). Image display is essentially as with the standard confocal microscope (Figure 7). 


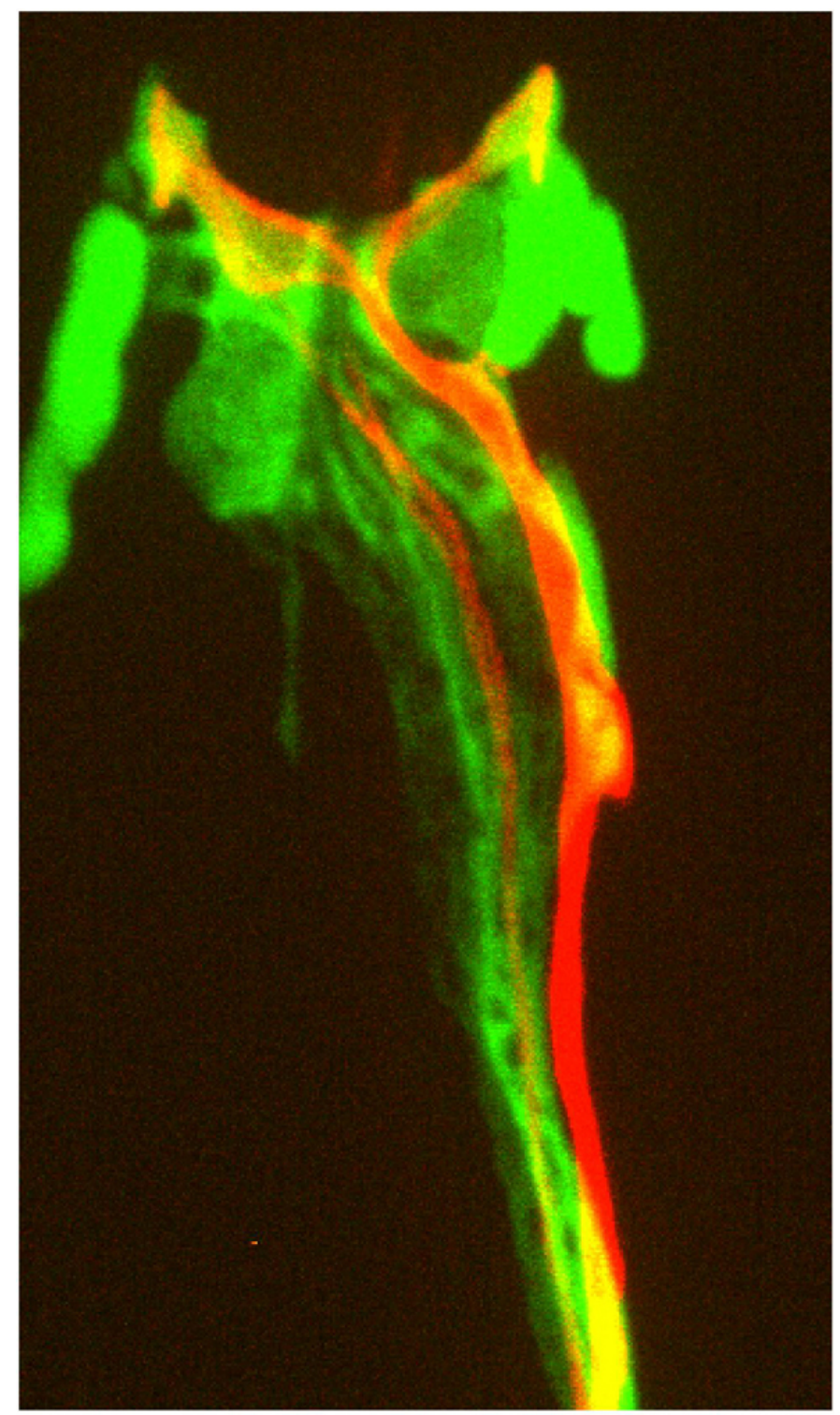

Figure 7. Spinning disc confocal microscope 2-dimensional projection of the amphid sheath cell (green) and the AWC and AWB amphidial neurons (red) (Taulant Bacaj and Shai Shaham).

\subsubsection{Multiphoton microscope}

The output from this microscope is similar to that from deconvolution or confocal microscopes. Thus, optical slices of images are generated that can be reconstructed to form a three dimensional image. Multiphoton microscopy eliminates out-of-focus light by directing excitation to the focal plane. This is accomplished by shining photons of long wavelengths and at high density onto the sample. At the focal plane long wavelength photons can superimpose to become, effectively, a shorter wavelength photon. This photon can now excite the fluorophore and induce fluorescence. Superposition of photons occurs significantly only at the focal plane. Multiphoton microscopy is also useful for looking at samples that are much thicker than confocal or deconvolution samples, with nearly equivalent resolution (Helmchen and Denk, 2002; Michalet et al., 2003).

\subsection{Electron microscopy}

Electron microscopy (EM) is currently the method of choice for examining subcellular structures in $C$. elegans. The resolution offered by the technique is unparalleled, allowing objects as small as, or even smaller than ribosomes to be viewed. Although EM is technically demanding, it is well worth the effort if resolution of small 
structures is of importance. Transmission EM (TEM) generally involves fixation of animals with any combination of gluteraldehyde, paraformaldehyde, or osmium tetraoxide ( $\left.\mathrm{OsO}_{4}\right)$, embedding of fixed animals in a special resin, sectioning animals (sections are usually 50-100 nm thick), staining, and imaging on an electron microscope (Hall, 1995; Figures 8 and 9). Fixation conditions are generally the key to a successful EM experiment. Standard treatments with fixatives are adequate for most applications, however, they have the disadvantage that cellular structures are often slightly distorted because of osmotic imbalance and other damage that occurs during the fixation procedure. High Pressure Freezing (HPF) has recently been employed to avoid these issues. Tissues and cells are generally rounder, and the ultrastructure seems to reflect the in vivo structures more accurately (Figure 10). Because HPF fixation has only recently come to prominence in $C$. elegans, a number of issues still remain to be addressed with the technique. Specifically, results are often more variable than using standard fixation. In addition, embryos and L1 larvae seem to fix better than older stages. Interestingly, embryo fixation using standard methods is fairly difficult, thus, HPF and standard techniques are somewhat complementary.

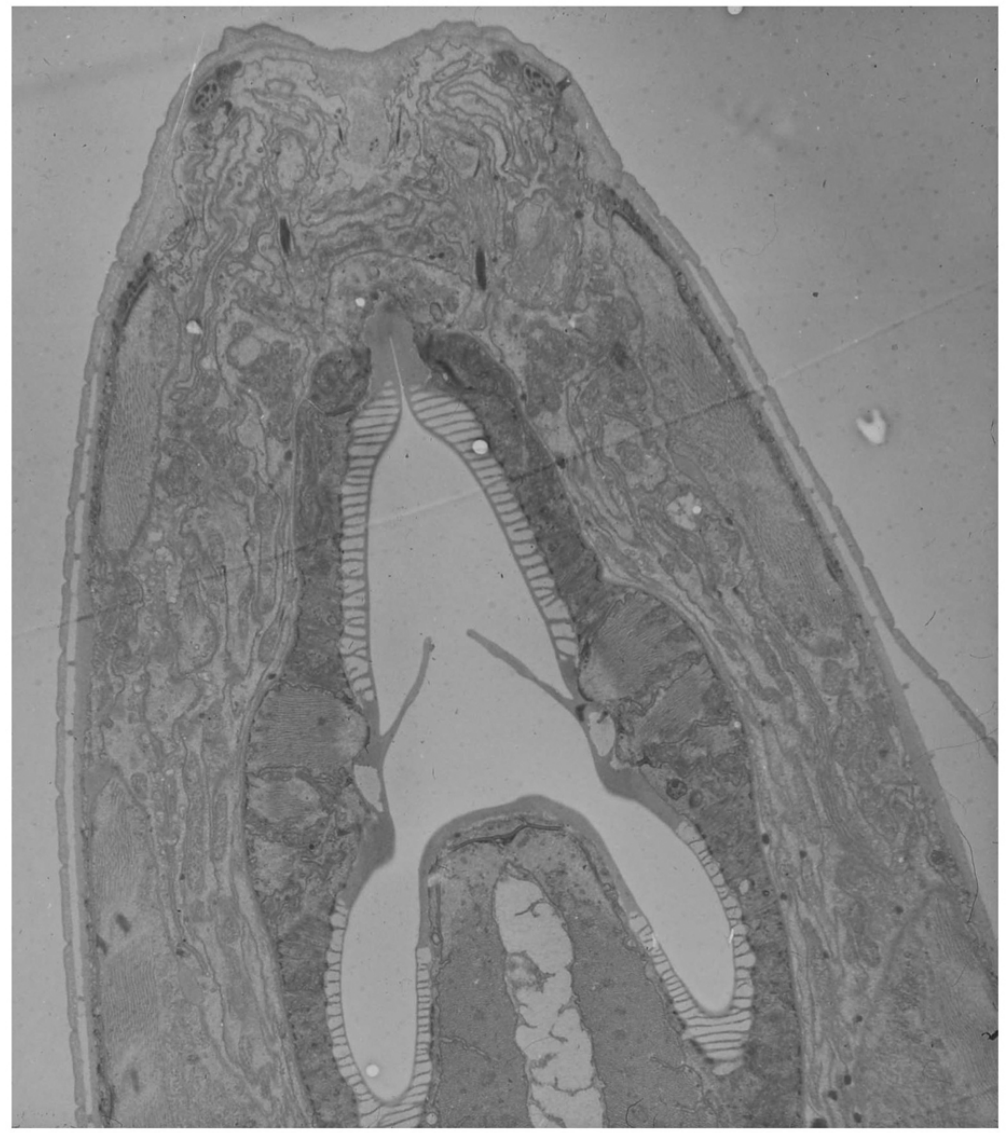

Figure 8. TEM micrograph of a longitudonal section of the C. elegans nose (Erika Hartwieg and Bob Horvitz). 


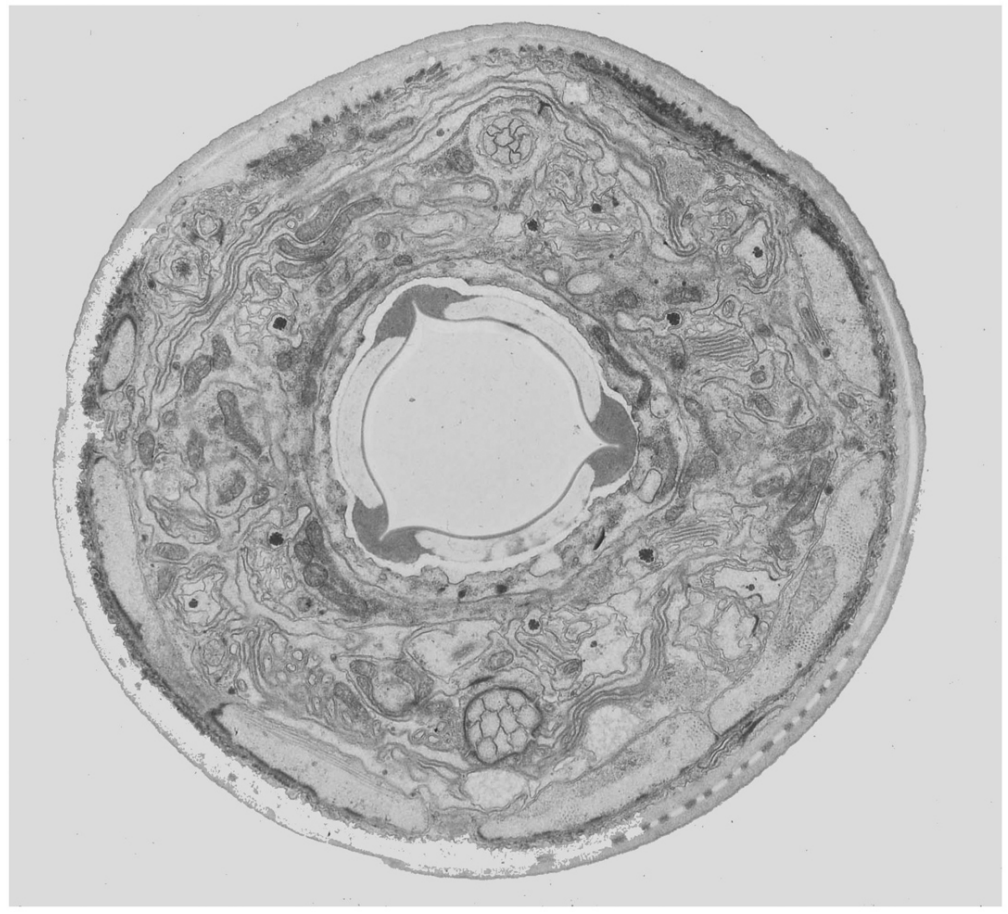

Figure 9. TEM micrograph of cross-section of C. elegans nose (Erika Hartwieg and Bob Horvitz).

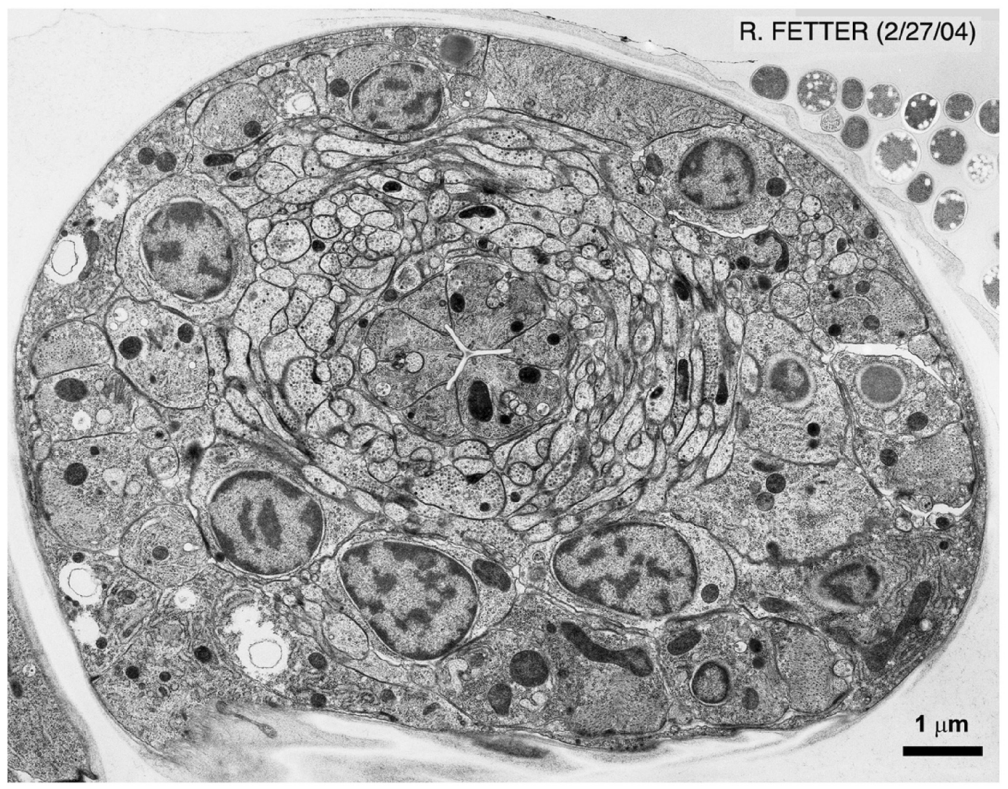

Figure 10. TEM section through an embryo fixed using HPF (Rick Fetter and Cori Bargmann).

Because fixation is so critical for good ultrastructure, we present below several alternative protocols for TEM. At the end of the section we present a method for scanning EM (SEM) of worms. In this method, whole-mount animals or structures are viewed by EM, offering both broad-scale and highly resolved images (Figure 11). 


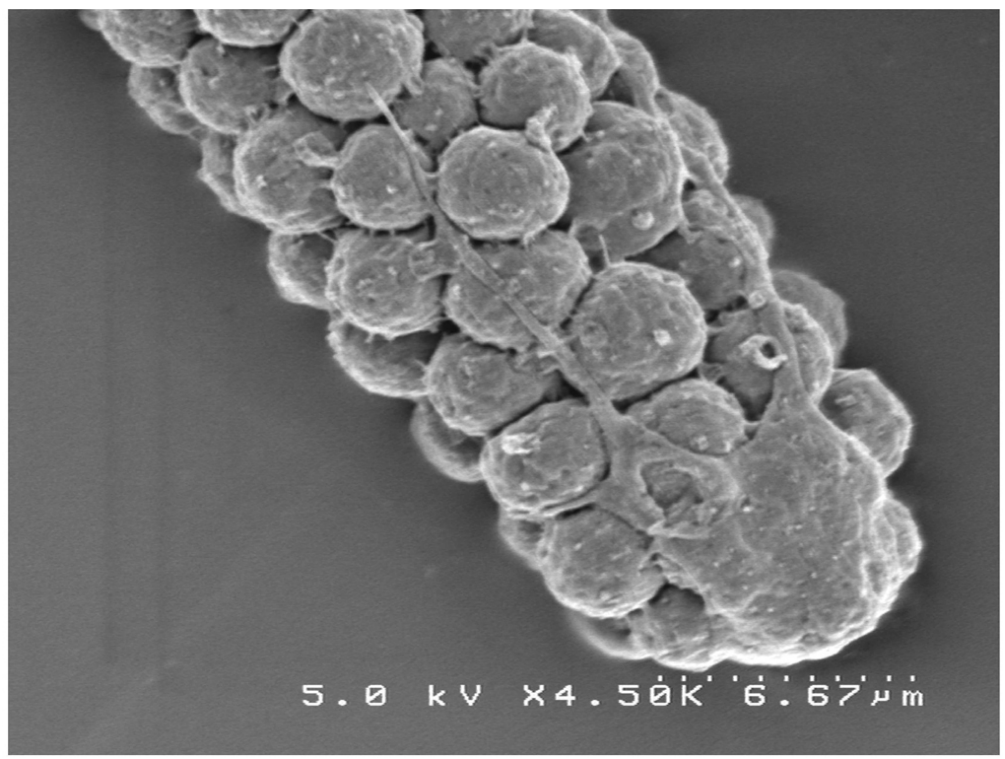

Figure 11. SEM of a dissected C. elegans gonad (David Greenstein).

The protocols below are intended to give a sense of the types of fixation procedures used for EM and should be used as guidlines for those with previous EM experience. These protocols are not intended for teaching EM from scratch.

\section{Protocol 8: Conventional two-step fixation for TEM (Dave Hall)}

1. Wash animals in M9 and anaesthetize in $8 \%$ alcohol in M9.

2. Fix in $2.5 \%$ glutaraldehyde, $1 \%$ paraformaldehyde in $0.1 \mathrm{M}$ sucrose, $0.05 \mathrm{M}$ cacodylate on ice, 2 hours.

3. Rinse $3 \mathrm{X}$ in $0.2 \mathrm{M}$ cacodylate on ice, $10 \mathrm{~min}$. each.

4. Fix in $0.5 \% \mathrm{OsO}_{4}, 0.5 \% \mathrm{KFe}(\mathrm{CN})_{6}$ in $0.1 \mathrm{M}$ cacodylate, $90 \mathrm{~min}$. on ice.

5. Wash $3 \mathrm{X}, 10 \mathrm{~min}$. each, in 0.1 cacodylate; Wash $3 \mathrm{X}, 10 \mathrm{~min}$. each in $0.1 \mathrm{M}$ NaAcetate.

6. Stain in $1 \% \mathrm{UAc}$ in $0.1 \mathrm{M} \mathrm{NaAcetate}, \mathrm{pH} 5.2$ at room temperature for $60 \mathrm{~min}$.

7. Rinse $3 \mathrm{X}$ in 0.1 NaAcetate, 5 min. each.

8. Rinse $3 \mathrm{X}$ in distilled water, leave overnight, embed cut pieces in $3 \%$ seaplaque agarose.

9. Cut out small agarose blocks containing worms; should be large enough to be excluded from pipette tip, but small enough to fit into embedding mold.

10. Dehydrate through ethanol series: $5 \mathrm{~min}$. in $30 \% \mathrm{EtOH}, 5 \mathrm{~min}$. in $50 \% \mathrm{EtOH}, 5 \mathrm{~min}$. in $75 \% \mathrm{EtOH}, 5 \mathrm{~min}$. in $95 \% \mathrm{EtOH}, 3$ X $10 \mathrm{~min}$. in $100 \% \mathrm{EtOH}, 3$ X $10 \mathrm{~min}$. ethanol, 3 X $10 \mathrm{~min}$ in 100\% propylene oxide; all at room temperature.

\section{Infiltration:}

First change is in 1 part resin to 2 parts propylene oxide, allow to sit for 3 hours.

Second change is in 2 parts resin to 1 part propylene oxide, for 5 hours.

Then change into fresh resin at least 3-4 times, 2-4 hours per change. 
11. Place samples in fresh resin at room temp; place samples in air-tight containers and agitate or rotate samples slowly. Rotation or agitation of the samples helps with the infiltration.

12. Place samples in fresh resin in embedding mold, and position carefully.

13. Cure samples in $60^{\circ} \mathrm{C}$ oven for 3 days.

\section{Resin formula}

$45 \mathrm{ml}$ Scipoxy 812. Other brands include Embed 812, Medcast, Epon

$30 \mathrm{ml}$ DDSA

25 ml NMA

Mix components well with wooden applicator, add accelerator, $1.5 \mathrm{ml}$ DMP-30, and mix resin thoroughly again. Place resin into dessicator and put under vacuum for 5-15 $\mathrm{min}$ to remove gasses from mixture before using

\section{Protocol 9: TEM fixation and sectioning (Erika Hartwieg and Bob Horvitz)}

1. Fixation

Rinse worms off plates with $\mathrm{M} 9$, then substitute with fixative: $0.8 \%$ Glutaraldhyde, $0.8 \% \mathrm{OsO}_{4}$ in $0.1 \mathrm{M}$ Cacodylate buffer pH7.4 (with $\mathrm{HCl}$ ).

Let sit on ice for $1 \mathrm{hr}$ in the dark, cut worms open close to tissue of interest, rinse $3 \mathrm{x}$ with $0.1 \mathrm{M}$ Cacodylate buffer.

2. Fixation

$2 \% \mathrm{OsO}_{4}$ in Cacodylate buffer overnight in fridge in wet chamber

3. Embedding in agar

Place 5-6 worms in a very small drop of buffer, withdraw the buffer and quickly place an agar drop over the worms and align worms with a hot worm-pick as closely as possible.

4. Dehydration and infiltration of resin

\begin{tabular}{|l|l|}
\hline $\begin{array}{l}\text { enbloc staining in } 1 \% \text { Uranyl acetate in 50\% } \\
\text { alcohol }\end{array}$ & $1 \mathrm{hr}$ \\
\hline $50 \%$ alcohol & $10 \mathrm{~min}$ \\
\hline $70 \%$ alcohol & $10 \mathrm{~min}$ \\
\hline $70 \%$ alcohol & $20 \mathrm{~min}$ \\
\hline $80 \%$ alcohol & $15 \mathrm{~min}$ \\
\hline $96 \%$ alcohol & $20 \mathrm{~min}$ \\
\hline $100 \%$ alcohol & $45 \mathrm{~min}$ \\
\hline $100 \%$ alcohol & $45 \mathrm{~min}$ \\
\hline Propylene Oxide/100\% alcohol & $20 \mathrm{~min}$ \\
\hline Propylene & $10 \mathrm{~min}$ \\
\hline Propylene & $10 \mathrm{~min}$ \\
\hline
\end{tabular}




\begin{tabular}{|l|c|}
\hline $25 \%$ Epon mixture/Propylene & $2 \mathrm{hrs}$ \\
\hline $50 \%$ Epon mixture/Propylene & $4 \mathrm{hrs}$ \\
\hline Full strength Epon mixture & $6-8 \mathrm{hrs}$ \\
\hline Freshly mixed full strength Epon mixture & $8 \mathrm{hrs}$ \\
\hline
\end{tabular}

\section{Epon mixture:}

13.0 g Eponate 812

5.5 g NMA

7.5 g DDSA

\section{$0.5 \mathrm{ml}$ DMP30}

5. Embedding for blocks to be cut

Place gelatin blocks into flat transparent embedding molds, blocks can be aligned according to cutting requirements, place mutant no. (label) into the mold.

6. Polymerize the resin at $65^{\circ} \mathrm{C}$. for $48 \mathrm{hrs}$

\section{Sectioning:}

1. Trim blocks and cut worms to the desired level with glass knives. Place 1 micron sections onto a coated grid and on to a drop of water on a glass slide, place on hotplate and stain with $1 \%$ tolluidin blue+ $15 \%$ borax to find desired level.

2. Trim excess plastic around the worms into a trapazoid form and dab on top and bottom sides of the block some "sticky wax" (wax found in graphic arts stores Charette ASTM D4236) especially for serial sections. Cut thin sections of light gray to white color. Long continuous ribbon of sections can then be picked up with a coated grid, where the sections according to the length of the slotted grid can be separated by eyelashes. Hold the ribbon of sections with eyelash in the left hand and pick up sections by submerging the grid underneath the water surface in the trough and then slowly come up at an angle.

Staining grids in a grid staining machine: $90 \mathrm{~min}$ in Stain No. 1

30 min in Stain No.2

Coating slotted grids: $0.5 \%$ Pioloform in very clean Chloroform

\section{Protocol 10: Osmium + Aldehyde one-step fixation for TEM (Dave Hall)}

1. Wash animals in M9 buffer and chill to $4^{\circ} \mathrm{C}$.

2. Fix in $0.5 \%$ Osmium, $1.25 \%$ glutaraldehyde in $0.1 \mathrm{M}$ HEPES, pH $7.4+0.14 \mathrm{M}$ sucrose, $4^{\circ} \mathrm{C}$ [CUT OPEN IN FIX ASAP WITH RAZOR BLADE]. After 30 min. allow samples to warm, 40-120 min.

3. Wash in 0.2M HEPES buffer, $0.1 \mathrm{M}$ NaAcetate.

4. Stain in $1 \%$ UAc in $0.1 \mathrm{M} \mathrm{NaAcetate,} \mathrm{pH} 5.2$, room temperature for $45-75 \mathrm{~min}$. 
5. Wash in $0.1 \mathrm{M}$ NaAcetate, 2 X $5 \mathrm{~min}$; in 0.2M HEPES.

6. Embed cut pieces in $3 \%$ agarose, positioning worms into clusters; allow to harden at $4^{\circ} \mathrm{C}$ for 1 hour, or overnight under buffer.

7. Cut out small agarose blocks containing worms; should be large enough to be excluded from pipette tip, but small enough to fit into embedding mold.

Dehydrate through ethanol series; 1-5 min in 30\% EtOH, 1-5 min in 50\% EtOH, 1-5min in $75 \% \mathrm{EtOH}, 2-5$ min in $95 \% \mathrm{EtOH}, 3 \times 10 \mathrm{~min}$ in $100 \% \mathrm{EtOH}, 3 \times 10 \mathrm{~min}$ in propylene oxide.

\section{Infiltration}

First change is in 1 part resin to 2 parts propylene oxide, allow to sit 3-4 hours or more.

Second change is in 2 parts resin to 1 part propylene oxide, for 3-4 hours or more, 1 part propylene oxide to 2 parts resin overnight, rotating.

The next day, place samples in fresh resin at room temperature; place samples in air-tight containers and agitate or rotate samples slowly during infiltration. Then change into fresh resin at least 3-4 times, 2-4 hours per change.

Embed samples in fresh resin in embedding mold, and position carefully.

Cure samples in $60^{\circ} \mathrm{C}$ oven for 3 days

Resin formula [use pre-dessicated plastic beaker with gradations for easy measurements]:

$45 \mathrm{ml}$ Scipoxy 812 Other brands include Embed 812, Medcast, Epon

$30 \mathrm{ml}$ DDSA

$25 \mathrm{ml}$ NMA

Mix components well with wooden applicator, add accelerator, $1.5 \mathrm{ml}$ DMP-30 and mix resin thoroughly again. Place resin into dessicator and put under vacuum for 5-15 $\mathrm{min}$ to remove gasses from mixture before using.

\section{Protocol 11: Microwave aldehyde fixation for TEM (Dave Hall)}

1. Wash animals in M9 buffer.

2. Add fixative (2.5\% glutaraldehyde, $1.0 \%$ paraformaldehyde in $0.1 \mathrm{M}$ HEPES) and microwave at "hotspot" according to the following schedule: $2 \mathrm{~min}$ ON, 2 min OFF, 2 min ON, 2 min OFF, 2 min ON, refreshing ice bath between "ON" sessions to keep samples cold throughout. After microwave bouts, continue soaking animals in same fix at room temp for one hour.

3. Wash $3 \times 10$ min in $0.2 \mathrm{M}$ HEPES buffer.

4. Fix in $1 \% \mathrm{OsO}_{4}, 0.5 \% \mathrm{KFe}(\mathrm{CN})_{6}$ in $0.1 \mathrm{M}$ HEPES pH 5.6, room temperature for $60 \mathrm{~min}$.

5. Wash in 0.2M HEPES, $2 \times 10 \mathrm{~min}$; wash in $0.1 \mathrm{M} \mathrm{NaAcetate} \mathrm{pH} 5.2,2 \times 10 \mathrm{~min}$.

6. Stain in $1 \%$ UAc in $0.1 \mathrm{M} \mathrm{NaAcetate}, \mathrm{pH} 5.2$, room temperature for $45 \mathrm{~min}$.

7. Wash in $0.1 \mathrm{M}$ NaAcetate, $2 \times 10 \mathrm{~min}$; wash in $0.2 \mathrm{M}$ HEPES, $2 \times 10 \mathrm{~min}$. 
8. Embed cut pieces in 3\% agarose, positioning worms into clusters; allow to harden at $4{ }^{\circ} \mathrm{C}$ for 1 hour, or overnight under buffer.

9. Cut out small agarose blocks containing worms; should be large enough to be excluded from pipette tip, but small enough to fit into embedding mold.

10. Dehydrate through ethanols; $5 \mathrm{~min}$ in $30 \% \mathrm{EtOH}, 5 \mathrm{~min}$ in $50 \% \mathrm{EtOH}, 5 \mathrm{~min}$ in $75 \% \mathrm{EtOH}, 5 \mathrm{~min}$ in $95 \%$ $\mathrm{EtOH}, 3 \times 10 \mathrm{~min}$ in $100 \% \mathrm{EtOH}, 3 \times 10 \mathrm{~min}$ in propylene oxide.

\section{Infiltration:}

1. Change is in 1 part resin to 2 parts propylene oxide, allow to sit 3-4 hours or more.

2. Change is in 2 parts resin to 1 part propylene oxide, for $3-4$ hours or more, 1 part propylene oxide to 2 parts resin overnight, rotating.

The next day, place samples in fresh resin at room temperature; place samples in air-tight containers and agitate or rotate samples slowly during infiltration. Then change into fresh resin at least 3-4 times, 2-4 hours per change

Embed samples in fresh resin in embedding mold, and position carefully.

Cure samples in $60^{\circ} \mathrm{C}$ oven for 3 days

Resin formula [use pre-dessicated plastic beaker with gradations for easy measurements]:

$45 \mathrm{ml}$ Scipoxy 812 Other brands include Embed 812, Medcast, Epon

$30 \mathrm{ml}$ DDSA

25 ml NMA

Mix components well with wooden applicator, add accelerator, $1.5 \mathrm{ml}$ DMP-30, and mix resin thoroughly again. Place resin into dessicator and put under vacuum for 5-15 min to remove gasses from mixture before using

\section{Special Equipment Needed}

Scientific microwave oven (we use a model from Ted Pella); kitchen ovens do not properly control the microwave energy pulses for this purpose. See (Paupard et al., 2001) for further details on use of the microwave oven.

\section{Protocol 12: High pressure freezing fixation (Dave Hall)}

1. Scoop animals off an NGM plate in a coating of E. coli using a pick. Place the animals and bacteria into a metal hat until interior compartment is full to the brim. Place a blank hat on top to seal the compartment and load into HPF machine to freeze. There should be no air space surrounding the sample within the metal hat [to obtain maximum pressure].

\section{Freeze Substitution}

2. Hold frozen sample at $-90^{\circ} \mathrm{C}$ for 3 days in $2.0 \% \mathrm{OsO}_{4}, 0.1 \%$ Uranyl Acetate in acetone fixative.

3. Warm sample to $-74^{\circ} \mathrm{C}$ in same fixative and then to $-60^{\circ} \mathrm{C}$ over 14 -hour period.

4. Warm sample to $-30^{\circ} \mathrm{C}$ in same fixative over 14-hour period. 
5. Warm sample to $0^{\circ} \mathrm{C}$ in same fixative over 1-hour period.

6. Transfer sample to $100 \%$ acetone three times at room temp, $20 \mathrm{~min}$ total.

\section{Infiltration}

First change is in 1 part resin to 1 part acetone, allow to sit $30 \mathrm{~min}$.

Second change is in 2 parts resin to 1 part acetone, allow to sit for $30 \mathrm{~min}$.

Third change is into pure resin plus accelerator and hold one hour.

Fourth change is into pure resin plus accelerator and hold overnight.

The next day, place samples in fresh resin plus accelerator at room temperature and place infiltrated worms in eppendorf tubes or gelatin capsules. Cure samples under UV irradiation overnight or until hard; keep at $-20^{\circ} \mathrm{C}$ while curing in Pelco Cryobox. If desired, cut best worms out of embedment and re-embed in resin at desired orientation and re-cure in sealed flat mold.

\section{$\underline{\text { Resin formula }}$}

\section{LR Gold resin plus 0.5\% BME accelerator}

\section{Special Equipment needed}

High Pressure Freeze apparatus; a very expensive item, but they are available at several national facilities including those in Madison, Minneapolis, Berkeley, and Albany. Freeze substitution apparatus; can be home-built or purchased

\section{Protocol 13: High pressure freezing and freeze substitution for TEM (Richard Fetter, Kent McDonald, Cori} Bargmann)

\section{HPF procedure with a Bal-Tec HPM 010:}

As with any ultra-rapid freezing method, the principal concern is optimizing the specimen geometry to maximize the heat transfer rate with the coolant used. Increasing the heat transfer rate is often best achieved by minimizing the size of the specimen chamber in the direction that the coolant is being applied. The Bal-Tec HPM 010 high-pressure freezing device has specimen holders that can be used to create specimen chambers that closely match the diameter of the specific C. elegans stage being frozen through the use of appropriate spacers.

The most suitable spacers found so far are slot, hole and Chien EM grids (ordered from Ted Pella, but probably available from other suppliers; thicknesses were measured with a Fowler 52-223-005 micrometer). Multiple grids can be used in combination to create specimen chambers of other thicknesses as needed:

\begin{tabular}{|l|l|l|}
\hline Grid & Ave. thickness $(\boldsymbol{\mu m})$ & Range $(\boldsymbol{\mu m})$ \\
\hline 9GC20H (“Chien”) & 27 & $27-28$ \\
\hline 1 GC42S & 35 & $33-37$ \\
\hline 1 GC12H & 48 & $47-50$ \\
\hline 1 GN42S & 27 & $26-29$ \\
\hline 1 GN12H & 58 & $54-65$ \\
\hline SynapTek DOT 4511 & 100 & $100-102$ \\
\hline
\end{tabular}


1. On the flat side of the Type B holder ( $300 \mathrm{~m}$ planchette), place a grid suitable in thickness to the worms being frozen. The new space within the hole/slot of the EM grid is the specimen chamber where the embryos/worms will go. Place a dab of $E$. coli in the chamber. (Briefly touching the grid to a thin $E$. coli lawn before placing it on the flat surface of the Type B holder will help keep the spacer in place for subsequent steps.)

2. Pick the embryos/worms you want and place them in the E. coli dab in the specimen chamber. I try to put about 10 embryos/worms in a sample to be frozen. That's plenty for sectioning in case the freezing is good, and not too many that if the freezing is bad that a lot effort has been wasted.

3. Fill the rest of the well with E. coli (preferred) or yeast paste as packing material, so that the level is flush with the top surface of the spacer. The consistency of the packing material is important. You want to avoid packing material that is too soupy because the higher water content does affect the freezing rate.

4. Place the flat side of a second Type B holder (300 m) on top of the embryos/worms.

5. Place this "sandwich" in the specimen freezing holder of the Bal-Tec HPM 010 and freeze.

6. Store the frozen sample intact in LN2 until processed.

\section{Freeze substitution protocol using a Leica AFS}

1. Under LN2, the frozen sample is split open with the tips of a pair of forceps previously cooled in LN2.

2. Transfer the holder(s) containing the sample to a $2.0 \mathrm{ml}$ Nalgene cryovial containing $1-1.5 \mathrm{ml}$ of frozen substitution medium $(0.5-1.0 \% \mathrm{OsO} / 0.1 \% \mathrm{UAc}$ in $2-5 \% \mathrm{MeOH} / 95-98 \%$ acetone for conventional $\mathrm{EM}$; low glut and/or $\mathrm{OsO}_{4}$ in 2-5\% MeOH/95-98\% acetone, or other cocktail, for immuno-EM) under $\mathrm{LN} 2$ and screw the cap on.

3. Transfer the vial to your freeze-substitution device. A Leica AFS is the easiest to use since the temperatures and durations of each step in the substitution can be programmed, however, perfectly adequate results can be obtained with "custom" freeze-substitution devices based on picnic coolers and dry ice.

For the Leica AFS device, I generally use the following protocol for conventional EM:

\begin{tabular}{|l|l|l|l|}
\hline Stage & Temp. or warming rate & Duration (hrs) & Total time (hrs) \\
\hline T1 & $-90^{\circ} \mathrm{C}$ & 72 & 72 \\
\hline $\mathrm{S} 1$ & $5^{\circ} \mathrm{C} / \mathrm{hr}$ & 13 & 85 \\
\hline $\mathrm{T} 2$ & $-25^{\circ} \mathrm{C}$ & 13.5 & 98.5 \\
\hline $\mathrm{S} 2$ & $10^{\circ} \mathrm{C} / \mathrm{hr}$ & 4.5 & 103 \\
\hline $\mathrm{T} 3$ & $+20^{\circ} \mathrm{C}$ & $2-17$ & $105-120$ \\
\hline
\end{tabular}

This typically gives good preservation and enhanced membrane contrast with well-frozen samples. There is, however, wide latitude in temperatures, warming rates, and durations of each step that give excellent results.

\section{Freeze-substitution using a "custom" freeze-substitution device}

When an automated freeze-substitution device, such as a Leica AFS, is not available, completely adequate freeze-substitution can be performed using a "custom" device and dry ice. In this case it is helpful to have a:

1. digital thermometer/thermocouple (Omega Engineering) to monitor temperature during the substitution process,

2. heat sink to buffer temperature changes, such as an aluminum block with holes just larger than the sample vials, 
3. insulated container to hold the samples, heat sink and about 40 pounds of dry ice (such as a Rubbermaid model 1827 picnic cooler), and

4. orbital shaker capable of holding up to $50 \mathrm{lbs}$ (Cole-Parmer model 51704 orbital shaker, 3/4" stroke).

Neoprene SCUBA diving gloves work great for manipulating the specimens and aluminum holder at LN2 and dry ice temps.

The insulated container should be allowed to cool down prior to loading samples for substitution, by filling it with dry ice about 30 minutes before use.

\section{Procedure:}

1. As with the Leica AFS procedure above, under LN2, the frozen sample "sandwich" is split open with the tips of a pair of forceps previously cooled in LN2.

2. Transfer the holder(s) containing the sample to a $2.0 \mathrm{ml}$ Nalgene cryovial containing $1.5 \mathrm{ml}$ of frozen substitution medium $(0.5-1.0 \%$ OsO $/ 0.1 \%$ UAc in $2-5 \% \mathrm{MeOH} / 95-98 \%$ acetone for conventional EM; low glut and/or $\mathrm{OsO}_{4}$ in 2-5\% MeOH/95-98\% acetone, or other cocktail, for immuno-EM) under LN2 and screw the cap on.

3. The cryovials are transferred to the aluminum holder in a styrofoam container, or dewar, previously equilibrated with LN2. Once all the sample vials are loaded, the aluminum holder is placed at a slight angle in the picnic container holding the dry ice, and some aluminum foil is wrapped around the block to keep the sample vials secured during substitution. The thermocouple is positioned through a small hole in the aluminum foil to a spot close to the sample vials, and the lid of the picnic cooler closed.

4. The picnic cooler is placed on the orbital shaker and fastened to the platform of the shaker with bungee cords. The shaker is turned on and set at 50-100 rpm. The substitution with this agitation is performed for 3-4 days, with replenishment of dry ice as needed to keep the specimen covered with dry ice.

5. Fill the cooler for the last time with dry ice 48 hours before the planned end of the substitution time. Over the 48 hours the dry ice will gradually disappear and the aluminum block will gradually warm. Remove the specimens at the desired end point temperature of the substitution and rinse the specimens with acetone at that temperature.

\section{Infiltration and embedding:}

\section{Resins}

For conventional EM I've been using a 1A:3B mixture of Eponate 12 or other Epon replacement resin. For immuno-EM, a number of resins are available that are amenable to UV polymerization at low temperature, including LR White, LR Gold, Unicryl and Lowicryl. Infiltration should be performed using a tissue rotator whenever possible.

\section{Conventional EM embedding}

1. At the completion of the freeze-substitution program, rinse the samples $2 \mathrm{x}$ with dry acetone, and then exchange the acetone for propylene oxide.

2. Infiltrate the samples with 1:2 propylene oxide:resin for 30 minutes followed by $2: 1$ resin:propylene oxide for 30 minutes, and then transfer to pure resin containing catalyst. An additional 2-3 changes of resin, 1-2 hours each, followed by an overnight change in resin will ensure complete infiltration of the worm. All infiltration steps should be performed with a tissue rotator.

In $100 \%$ resin, the embryo/worm plus E.coli/yeast pancake usually comes out of the holder. A sharpened tungsten needle can be used to CAREFULLY and GENTLY chip the packing material away from the embryos/worms. It is fine to leave the worms in the packing material, but it is a little harder to see the them to 
orient for sectioning.

3. In order to have maximum control over the orientation of the worms for sectioning, I prepare blocks for sectioning in 2 stages. First, I flat embed the worms between 2 glass slides previously coated with spray-on Teflon (Cat. No. MS-122DF from the Miller-Stephenson Chemical Co., George Washington Hwy, Danbury, CT 06810, (203) 743-4447. Previously coat one side of each pair of glass slides, allow to dry, and then wipe off the white residue with a Kimwipe). A doubled-over piece of Parafilm at each end of the slide works well as a spacer to prevent the worms from being crushed. After polymerization, a razor blade is used to gently pry the slides apart.

Using a razor blade, cut out the worms to be sectioned and re-embed them in regular molds in the desired orientation. Polymerize as usual $\left(48 \mathrm{hrs}\right.$ at $60-70{ }^{\circ} \mathrm{C}$ ). The teflon does not seem to interfere with the adhesion of the resin containing the worm with the fresh resin it is re-embedded in. I have not experienced separation at this junction during thin sectioning.

\section{Immuno-EM embedding}

1. Rinse the samples $2 \mathrm{x}$ with dry acetone and then infiltrate with your immuno-EM resin of choice as usual.

As a general rule, infiltration and embedding at low temperature $\left(-20^{\circ} \mathrm{C}\right.$ or lower) is preferable to room temperature for preserving antigenicity. For an immuno-EM resin, I have used LR White since it was more "fluid" at $-20^{\circ} \mathrm{C}$ than Lowicryl and can be UV polymerized using $1.5 \mathrm{mg} / \mathrm{ml}$ resin of benzoin ethyl ether as the UV catalyst. The trick is to add and dissolve $1.5 \mathrm{mg} / \mathrm{ml}$ of benzoin ethyl ether in the LR White at room temperature, then de-gas the resin (since UV polymerization forces the dissolved gas out of the resin and unfortunately around the tissue) before you cool it down to $-20^{\circ} \mathrm{C}$ for infiltration.

2. Following infiltration, place the worms in molds and polymerize with UV for $24 \mathrm{hrs}$ at $-20^{\circ} \mathrm{C}$ followed by $2-10 \mathrm{hrs}$ at room temperature.

LR White polymerization is very sensitive to oxygen. To avoid getting an unpolymerized film of resin at the top of the mold, I place a strip of ACLAR film (Ted Pella) on top of the mold, taking care not to trap a bubble of air, after I put the worm in and fill the mold with resin. Unlike most plastic films, ACLAR has very low permeability to oxygen.

\section{Protocol 14: Fixation of embryos for TEM (Carolyn Norris, Dave Hall)}

1. Mount embryos on slides as if for DIC except agar has fixative.

\section{Agarose Fixative}

$3 \mathrm{ml} 2 \%$ Agarose : $1.5 \%$ LGT Agarose $+.05 \%$ HGT Agarose

5 ul $1 \mathrm{M} \mathrm{MgCl}_{2}$

400 ul 0.2 M NaCacodylate (pH 7.4)

$400 \mathrm{ul}$ sucrose $(68.46 \mathrm{~g} / 100 \mathrm{ml})$

500 ul 25\% Glutaraldehyde

Make up above mixture immediately before mounting embryos. The pad should be thick, so use triple thickness tape when preparing slide. Transfer the eggs to pads with minimal fluid (to preserve osmolarity). Transfer with a pick or mouth pipette. Use an eyebrow hair to push the eggs to the center and arrange them so that they are close to each other without touching.

2. Overlay a small amount of slightly cooled agarose mix on slide and place a coverslip on top. Try either $12 \mathrm{~mm}$ 
or $18 \mathrm{~mm}$ coverslips.

3. Make a map of the embryos- their arrangement on the pad, their orientation, and their relative stages. Mount a bunch of 1,2 , and 4 cell embryos on a pad, then watch them go through landmark events, like gastrulation, the migration of the dorsal hyp nuclei, or cell deaths to stage them.

4. When an embryo reaches the stage you want, permeabilize the egg shell and vitelline membrane with a laser. Shoot for edge of shell. You can see the break in the shell and the membrane. The laser needs to be at full power. Also kill (explode) any embryos that you don't want and record their positions on your "map". Before fixing the final specimens, try several trial embryos with differing amounts of sucrose in the final fixative. While watching under the microscope, shoot several laser holes in the eggshell. If the embryo collapses rapidly (implodes), then the sucrose concentration is too high. If the embryo blows up rapidly (explodes), then the sucrose is too low. Under optimal conditions, the embryo will be seen to swell in volume very slowly after a laser hole is put through the eggshell. Thus the final fixative should be tested empirically on the day of fixation, to optimize the exact osmolarity.

5. Place the slide in a humidified chamber at room temperature for 2 hours to allow fixation.

6. Remove the coverslip by pipetting $25 \mathrm{mM}$ NaHEPES ( $\mathrm{pH} 7.5$ ) around the base of the pad, then gently slide the coverslip off. Eggs will usually stay in place.

7. Begin dehydrations and washes. Either leave the group in their original agar pads, or cut up the pad and place individual eggs in separate wells of a 9-well glass plate. Either way, trim the agarose with a clean new razor blade.

8. Rinse in NaHEPES: $2 \times 30^{\prime \prime}$, then $1 \times 2^{\prime}$.

9. Wash in $0.2 \mathrm{M} \mathrm{Na}$ Cacodylate $\mathrm{pH} 7.4,2 \times 30^{\prime \prime}, 1 \times 5^{\prime}, 1 \times 10^{\prime}, 2 \times 1 \mathrm{hr}$.

10. Post-Fix in $1 \% \mathrm{OsO}_{4}+1 \% \mathrm{KFe}(\mathrm{CN})_{6}$ in $.2 \mathrm{M} \mathrm{NaCacodylate}$ for 1 to 2 hours.

11. Wash in $0.1 \mathrm{M}$ NaCacodylate: $2 \times 30^{\prime \prime}, 1 \times 5^{\prime}, 2 \times 10^{\prime}$.

12. Post-Fix in $0.2 \%$ tannic acid in $0.1 \mathrm{M}$ Cacodylate for $15^{\prime}$.

13. Wash in $0.1 \mathrm{M}$ NaCacodylate $2 \times 30^{\prime \prime}, 1 \times 5^{\prime}, 2 \times 10^{\prime}$.

14. Wash in $0.1 \mathrm{M}$ NaAcetate, $2 \times 30^{\prime \prime}, 1 \times 5^{\prime}, 1 \times 10^{\prime}, 1 \times 30^{\prime}$.

15. Stain with $1 \%$ Uranyl Acetate in $0.1 \mathrm{M}$ NaAcetate for 3 hours.

16. Wash in in NaAcetate $2 \times 30^{\prime \prime}, 2 \times 10^{\prime}$.

17. Wash in $0.1 \mathrm{M}$ HEPES $1 \times 30^{\prime \prime}, 2 \times 5^{\prime}$.

18. Before the dehydration series, remount the embryos into large chunks ( 1 cc) of agar (2\%) and then cut each block into a distinct shape so that every embryo can be distinguished from all the other embryos. The larger blocks help protect the embryos as you go through all the steps and they are also much easier to see (and therefore to avoid sucking into your pipette and discarding). The distinct shapes allow you to dehydrate all the embryos in the same vial without confusing them.

19. Rinse the blocks in $\mathrm{dH}_{2} 0$ and transfer to a vial such as a scintillation vial.

20. Dehydration: 6' $30 \% \mathrm{EtOH}, 10^{\prime} 50 \% \mathrm{EtOH}, 10^{\prime} 70 \% \mathrm{EtOH}$, [if you need to take a break, this is a safe place to halt processing overnight], 6' $90 \% \mathrm{EtOH}, 6{ }^{\prime} 95 \% \mathrm{EtOH}, 3 \times 20$ ' 100\% EtOH, 20' 1:1 Propylene Oxide:EtOH, 2 $\times 8^{\prime}$ Propylene Oxide, 30' Propylene Oxide:Araldite 2:1, 60' Propylene Oxide:Araldite 1:2, $2 \times 30^{\prime}$ Araldite Room Temperature. 
Trim the blocks and return embryos to separate wells of a 9 well plate.

24 hrs Araldite RT.

Transfer blocks to whatever mold you will use to hold the embryo and try your best to orient embryo for easiest trimming and cutting.

3 days Araldite @ $60^{\circ} \mathrm{C}$.

\section{Buffer Recipes}

\section{$\underline{0.2 \mathrm{M} \mathrm{NaCacodylate}}$}

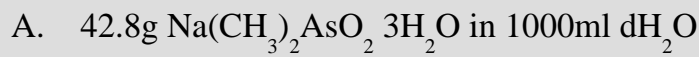

B. $0.2 \mathrm{M} \mathrm{HCl}\left[10 \mathrm{ml}\right.$ conc. $\left.\mathrm{HCl}+603 \mathrm{ml} \mathrm{dH}_{2} \mathrm{O}\right]$

$50 \mathrm{ml} \mathrm{A}+\mathbf{B} / 18.3 \rightarrow \mathrm{pH} / 6.4$ Q.S. to $200 \mathrm{ml}$

\section{Protocol 15: Preparing worm gonads for SEM (David Greenstein)}

1. Select L4 hermaphrodites en masse.

2. Grow overnight (12-16 hrs) to adult stage.

3. Transfer to unseeded plate to remove bacteria.

4. Transfer to a watch glass with $0.5 \mathrm{ml}$ of $1 \mathrm{X}$ PBS.

5. Wash worms with one change of $1 \mathrm{X}$ PBS.

6. Dissect gonads in $1 \mathrm{x}$ PBS containing $0.05 \%$ tricane $/ 0.005 \%$ tetramisole.

7. Transfer to a $6 \times 50 \mathrm{~mm}$ borosilicate glass tube.

8. Recover the gonads by centrifugation at $1000 \mathrm{rpm}$ in a IEC clinical centrifuge for $2 \mathrm{~min}$. at room temperature.

9. Digest the gonadal basal lamina by incubation with $20-40$ units $/ \mathrm{ml}$ of Type II collagenase in 1x PBS for 2-12 min at room temperature.

10. After digestion place gonads on ice and gently remove supernatant from gonads which had settled during incubation period.

11. Because gonads are fragile until fixed, add all solutions slowly. Wash gonads with cold 1x PBS, allowing the gonads to settle by gravity.

12. Fix the gonads with $3 \%$ glutaraldehyde in $0.1 \mathrm{M}$ sodium phosphate buffer $(\mathrm{pH} 7.2)$ for $4 \mathrm{hrs}$ on ice.

13. After they are fixed, wash the gonads three times with cold $0.1 \mathrm{M}$ sodium phosphate buffer ( $\mathrm{pH} 7.0)$ containing $5 \%$ sucrose, incubating on ice for 15 min. during each wash.

14. After the final wash pipette the gonads into a watch glass and hand select intact gonads under a dissecting scope.

15. Postfix the gonads in $1 \%$ osmium tetroxide in $0.1 \mathrm{M}$ sodium phosphate buffer $(\mathrm{pH} 7.2)$ for $1 \mathrm{hr}$ at room temperature. 
16. Rinse gonads in several changes of $0.1 \mathrm{M}$ sodium phosphate buffer ( $\mathrm{pH}$ 7.2).

17. Dehydrate in an ethanol series $(50,70,95,100 \%)$.

18. Dehydrate again in pure ethanol.

19. Place gonads in the cooled chamber of a critical point drier with the samples being covered with ethanol. To prevent the gonads from being damaged when the solvent enters or is vented from the chamber, place the gonads between several layers of filter paper cut with a standard hole punch.

20. Transfer dried samples to aluminum stubs covered with double stick tape using a camel-hair brush.

21. Desiccate overnight and then coat with gold using a sputter coat.

\section{Protein-protein and protein-DNA interactions}

An important task in deciphering protein function is the identification of other entities with which it interacts. Although C. elegans has not been exploited as an organism for biochemical analysis it is clearly amenable to such studies. Below are protocols describing immunoprecipitation (IP) and chromatin immunoprecipitation (ChIP) that should serve as general guidelines for in vivo interaction studies in C. elegans. These interactions can often be confirmed by standard in vitro techniques such as two-hybrid, GST pull-down studies, and electrophoresis mobility shift assays (EMSA).

\section{Protocol 16: Immunoprecipitation from embryo lysates (Ray Chan and Barbara Meyer)}

\section{Worm Liquid Culture:}

\section{Seeding asynchronous liquid worm culture}

1. Float adults worms off 9 -cm NGM plates with $5 \mathrm{ml}$ of M9. Approximately 6-8 plates saturated with asynchronous population of worms, but not starved, will be needed to seed each liter of liquid culture.

2. Add 10-15 $\mathrm{ml}$ of saturated HB101 and monitor the food supply at least once per day. Spot 1 drop of culture onto a 5-cm NGM plate and allow the liquid to evaporate for about 1-2 minutes until the worms can crawl. If there is sufficient food, the worms should not scatter or forage. Alternatively, starved worms appear somewhat translucent.

\section{$\underline{\text { Harvesting asynchronous culture and seeding synchronous cultures }}$}

1. Filter culture through a $35-\mu \mathrm{m}$ miracloth (Calbiochem) to collect gravid hermaphrodites.

2. Wash with approximately $0.5 \mathrm{~L}$ of $\mathrm{dH}_{2} \mathrm{O}$.

3. Treat each liter of culture with $100 \mathrm{ml}$ of freshly made alkaline-bleach solution. Mix on a stir-plate for 5-10 minutes (for mutant worms, it may be advisable to bleach for less than 5 minutes). Stop the bleaching process when the adult worms start to break open.

Alkaline-bleach solution $(100 \mathrm{~mL})$ :

$75 \mathrm{~mL} \mathrm{H}_{2} \mathrm{O}$

$20 \mathrm{~mL}$ commercial bleach

$5 \mathrm{~mL} 10 \mathrm{~N} \mathrm{NaOH}$

4. Weigh a $250-\mathrm{mL}$ conical centrifuge tube. Record weight g.

5. Centrifuge the bleached worms at $1-2,000 \mathrm{rpm}$ in a tabletop centrifuge. Stop the centrifuge as soon as the speed 
reaches 2,000 rpm. (It takes several minutes for the rotor to come to a complete stop).

6. Resuspend the worm in M9 and centrifuge as in step 5. Repeat this wash step once more for a total of two M9 washes.

7. Weigh the centrifuge tube with the washed embryos.

Combined weight of centrifuge tube and embryos g.

Weight of the embryos g.

8. Seed 0.5 to 2 grams of embryos per 1-L completed S-basal medium. Generally use $0.5-1 \mathrm{~g}$ for N2 and $1-2 \mathrm{~g}$ for mutant worms. Allow the embryos to hatch overnight without food and feed the synchronized L1 larvae the next day.

9. Wash unused embryos in homogenization buffer, resuspend in $1 \mathrm{~mL}$ of homogenization buffer per gram of embryo and store in $-80^{\circ} \mathrm{C}$ freezer.

\section{Embryo Lysates}

All steps are performed at $4^{\circ} \mathrm{C}$.

1. Thaw $10-15 \mathrm{~mL}$ of embryos frozen in homogenization buffer.

2. Place the tube on ice and sonicate it with ten 30 -second bursts at $15 \%$ power on a Heat System XL2020 sonicator with a standard tapered microtip (cat.\#419, $3 \mathrm{~mm}$ diameter). Wait 1 minute in between bursts for cooling.

3. Pellet debris by centrifugation at $6,500 \mathrm{rpm}(5,000 \times \mathrm{g})$ in a SS-34 rotor for 20 minutes. Collect the supernatant in a clean $50-\mathrm{mL}$ tube.

4. Sonicate as described in step 2 to shear the DNA. Pellet debris by centrifugation at $14,500 \mathrm{rpm}(25,000 \times \mathrm{g})$ in a SS-34 rotor for 20 minutes. Collect and quick-freeze the supernatant in $0.5-1 \mathrm{~mL}$ aliquots.

\section{Immunoprecipitation}

\section{All steps performed at $4^{\circ} \mathrm{C}$.}

1. Thaw embryo lysates on ice. Incubate lysates with Protein A Sepharaose beads $(100 \mu \mathrm{L}$ per mL lysates; Amersham) or IgGsorb (100 $\mu \mathrm{L}$ per $\mathrm{mL}$ lysates; The Enzyme Center) for 10-30 minutes. Spin in a microcentrifuge for $2 \mathrm{~min}$. at $500 \times g$ to pellet the Sepharose beads or IgGsorb. Transfer the supernatant to a new microfuge tube and spin in a microcentrifuge at top speed for $10 \mathrm{~min}$. Use the supernatant for IP.

2. Incubate approximately $5 \mu \mathrm{g}$ of affinity purified antibodies with $3 \mathrm{mg}$ total protein of embryo lysates for $2 \mathrm{hrs}$. Bring the final volume up to 1.0 to $1.4 \mathrm{~mL}$ using ChIP buffer with $140 \mathrm{mM} \mathrm{KCl}$.

3. Pellet non-specific precipitates by spinning in a microcentrifuge at top speed (approximately $16,000 \times g$ ) for 10 $\min$.

4. Transfer the supernatant to a new microfuge tube with $25 \mu \mathrm{L}$ of Protein A Sepharose and place on a rocker/nutator for $30 \mathrm{~min}$.

5. Pellet the antibody-antigen complexes captured on the Protein A Sepharose beads by spinning in a microcentrifuge for $2 \mathrm{~min}$. at $500 \times \mathrm{g}$. Remove the supernatant.

6. Wash the beads by adding $1 \mathrm{~mL}$ of ChIP buffer and spinning in a microcentrifuge for $2 \mathrm{~min}$. at $500 \times g$. Remove the wash buffer. Repeat this step for a total of four washes. 
7. Elute by boiling the beads with $1 \mathrm{x}$ SDS sample buffer and loading directly onto an SDS-PAGE gel. Alternatively, incubate the beads with $200 \mu \mathrm{L}$ of $0.1 \mathrm{M}$ glycine (pH 3.0) at room temp. Pellet the beads as described above, remove and save the supernatant. Precipitate the eluate with trichloroacetic acids.

For buffer recipes see the Chromatin Immunoprecipitation protocol below.

\section{Protocol 17: Chromatin Immunoprecipitation From Embryo Lysates (Ray Chan and Barbara Meyer)}

\section{Formaldehyde cross-linking:}

1. Harvest embryos by bleaching gravid hermaphrodites. [A typical yield for $\mathrm{N} 2$ is $2-5$ grams from 25 to $309-\mathrm{cm}$ NGM plates].

2. Wash the embryos extensively with $1 \mathrm{x}$ M9 to remove the alkaline bleach solution.

3. Prepare $100 \mathrm{~mL}$ of formaldehyde solution [1 x M9 solution with $2 \%(\mathrm{v} / \mathrm{v})$ formaldehyde]

4. Wash the embryos once in the formaldehyde solution. Aspirate away the wash solution. Add fresh formaldehyde solution to $50 \mathrm{~mL}$ and gently shake (using a nutator) at room temp for 30 minutes.

5. Wash the cross-linked embryos once with $50 \mathrm{~mL}$ of $0.1 \mathrm{M}$ Tris- $\mathrm{HCl}(\mathrm{pH} 7.5)$, followed by two 50 -mL washes of $1 \mathrm{x}$ M9.

6. Wash the embryos once with homogenization buffer. Add $1 \mathrm{~mL}$ of homogenization buffer per gram embryo (based on the starting amount), quick-freeze and store at $-80^{\circ} \mathrm{C}$.

\section{Extract prep:}

1. Thaw $10-15 \mathrm{~mL}$ of cross-linked embryos and add fresh protease inhibitors.

2. Place the tube on ice and sonicate it with ten 30-second bursts at $15 \%$ power on a Heat System XL2020 sonicator with a standard tapered microtip (cat.\#419, $3 \mathrm{~mm}$ diameter). Wait 1 minute in between bursts for cooling.

3. Pellet debris by centrifugation at $6,500 \mathrm{rpm}(5,000 \times \mathrm{g})$ in a SS-34 rotor for 20 minutes. Collect the supernatant in a clean $50-\mathrm{mL}$ tube.

4. Sonicate as described in step 2 to shear the DNA. Pellet debris by centrifugation at $14,500 \mathrm{rpm}(25,000 \times \mathrm{g})$ in a SS-34 rotor for 20 minutes. Collect and quick-freeze the supernatant in $0.5-1 \mathrm{~mL}$ aliquots.

IP:

1. Thaw embryo lysates on ice. Incubate lysates with Protein A Sepharaose beads $(100 \mu \mathrm{L}$ per mL lysates; Amersham) or IgGsorb (100 $\mu \mathrm{L}$ per $\mathrm{mL}$ lysates; The Enzyme Center) for 10-30 minutes. Spin in a microcentrifuge for $2 \mathrm{~min}$. at $2,000 \times g$ to pellet the Sepharose beads or IgGsorb. Transfer the supernatant to a new microfuge tube and spin in a microcentrifuge at top speed for $10 \mathrm{~min}$. Use the supernatant for IP.

2. Incubate approximately $5 \mu \mathrm{g}$ of affinity purified antibodies with $3 \mathrm{mg}$ total protein of embryo lysates for $2 \mathrm{hrs}$.

3. Pellet non-specific precipitates by spinning in a microcentrifuge at top speed (approximately $16,000 \times g$ ) for 10 min.

4. Transfer the supernatant to a new microfuge tube with $25 \mu \mathrm{L}$ of Protein A Sepharose and place on a rocker/nutator for $30 \mathrm{~min}$.

5. Pellet the antibody-antigen complexes captured on the Protein A Sepharose beads by spinning in a 
microcentrifuge for $2 \mathrm{~min}$. at $500 \times \mathrm{g}$. Remove the supernatant.

6. Wash the beads as follows:

2x 1-mL of ChIP buffer with $100 \mathrm{mM} \mathrm{KCl}$

2x 1-mL of ChIP buffer with $1 \mathrm{M} \mathrm{KCl}$

2x 1-mL of TE

7. Add $200 \mu \mathrm{L}$ elution buffer [10 mM Tris- $\mathrm{HCl}(\mathrm{pH} 8), 1 \%$ (w/v) SDS]. Spin to pellet the beads. Transfer eluate to a clean microfuge tube. Repeat elution step once more. Combine the eluates ( $400 \mu \mathrm{L}$ total vol).

8. Add $16 \mu \mathrm{L}$ of $5 \mathrm{M} \mathrm{NaCl}$ and heat overnight at $65^{\circ} \mathrm{C}$ to reverse the formaldehyde cross-links. [Use a PCR machine with a heated top or a Hybaid oven to avoid condensation at top of the tube].

9. Adding $8 \mu \mathrm{L}$ of $0.5 \mathrm{M}$ EDTA and $16 \mu \mathrm{L}$ of $1 \mathrm{M}$ Tris- $\mathrm{HCl}$ (pH 6.8). Mix. Digest proteins with $20 \mu \mathrm{g}$ of proteinase $\mathrm{K}$ (Boehringer Mannheim) for 1 hour at $45^{\circ} \mathrm{C}$.

10. Phenol-chloroform extractions. Add 10-20 $\mu$ g of glycogen. Mix. EtOH precipitate. Resuspend in $100 \mu \mathrm{L}$ TE.

\section{Buffer Recipes}

M9 buffer: $6 \mathrm{~g} \mathrm{Na}_{2} \mathrm{HPO}_{4}, 3 \mathrm{~g} \mathrm{KH}_{2} \mathrm{PO}_{4}, 5 \mathrm{~g} \mathrm{NaCl}, 0.25 \mathrm{~g}$ of $\mathrm{MgSO}_{4} 7 \mathrm{H}_{2} \mathrm{O}$ per liter. Autoclave.

$1 \mathrm{M}$ potassium citrate, $\mathrm{pH}$ 6.0: Per liter solution, add $268.8 \mathrm{~g}$ tripotassium citrate, $26.3 \mathrm{~g}$ citric acid monohydrate and adjust $\mathrm{pH}$ with $\mathrm{KOH}$. Autoclave to sterilize.

Trace metals solution: Per liter solution, add $1.86 \mathrm{~g} \mathrm{Na}_{2}$ EDTA, $0.69 \mathrm{~g} \mathrm{FeSO}_{4} \cdot 7 \mathrm{H}_{2} \mathrm{O}, 0.2 \mathrm{~g} \mathrm{MnCl}_{2} \cdot 4 \mathrm{H}_{2} \mathrm{O}, 0.29 \mathrm{~g}$ $\mathrm{ZnSO}_{4} \cdot 7 \mathrm{H}_{2} \mathrm{O}, 0.016 \mathrm{~g} \mathrm{CuSO}_{4}$. Autoclave to sterilize and store in the dark.

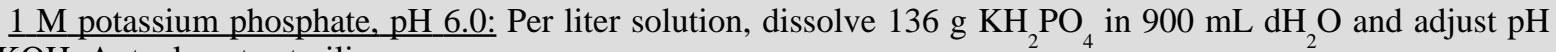
with $\mathrm{KOH}$. Autoclave to sterilize.

$10 \times \mathrm{S}$ basal medium: Per liter solution, add $59 \mathrm{~g}$ of NaCl, $500 \mathrm{~mL}$ of $1 \mathrm{M}$ potassium phosphate $(\mathrm{pH} 6), 10 \mathrm{~mL}$ of cholesterol (5 mg/mL in EtOH). Autoclave to sterilize. [Note: the cholesterol will not go into solution].

Complete S medium: Per liter, add $100 \mathrm{~mL}$ of $10 \times \mathrm{S}$ basal medium, $10 \mathrm{~mL} 1 \mathrm{M}$ potassium citrate (pH 6), 10 $\mathrm{mL}$ trace metals solution, $3 \mathrm{~mL} 1 \mathrm{M} \mathrm{MgSO}_{4}, 3 \mathrm{~mL} 1 \mathrm{M} \mathrm{CaCl}_{2}$. Autoclave to sterilize.

Homogenization buffer: 50 mM HEPES-KOH, pH 7.6; 1 mM EDTA; $140 \mathrm{mM} \mathrm{KCl;} \mathrm{0.5 \%} \mathrm{NP-40;} 10 \%$ glycerol. Add fresh protease inhibitors (aprotinin, pepstatin A, leupeptin, PMSF) and $5 \mathrm{mM}$ DTT before use.

ChIP buffer: $50 \mathrm{mM}$ HEPES-KOH, pH 7.6; $1 \mathrm{mM}$ EDTA; 0.05\% NP-40. Add $\mathrm{KCl}$ to the desired concentration. Add fresh protease inhibitors (aprotinin, pepstatin A, leupeptin, PMSF) and $1 \mathrm{mM}$ DTT before use. [This buffer contains less NP-40 and no glycerol compared to the homogenization buffer].

\section{Protocol 18: Chromatin immunoprecipitation (Johnathan Whetstine and Yang Shi)}

This protocol is a modified version of a protocol from Upstate Biotechnologies (www.upstate.com).

Chromatin is isolated from $3 \times 10^{5}$ embryos/ChIP reaction, which equates to no less than $400 \mu \mathrm{g}$ chromatin per immunoprecipitation (IP). There is no harm in scaling up for cleaner results, especially with poor antibodies.

1. Adult N2 worms grown on either HB101 or RNAi expressing bacteria are bleached and washed before being immersed and rotated in $1.5 \%$ Formaldehyde/M9 buffer for 30 minutes at $16{ }^{\circ} \mathrm{C}$. 
2. Embryos are washed extensively with M9 (at least 3 times) and gently centrifuged. Be careful not to rupture embryos.

3. Add warm chromatin SDS lysis solution $\left(30^{\circ} \mathrm{C}\right.$; Upstate biotechnologies cat. \# 20-163) to the embryos (minimum of $3 \times 10^{5}$ embryos per $200 \mu \mathrm{l}$ solution) and dounce homogonize at least 30 times.

4. Place the slurry on ice for at least 20-30 minutes.

5. Combine the total amount of embryos or adults and sonicate 25 times per $2 \mathrm{ml}$ of extract used for an approximately $500 \mathrm{bp}$ smear (15 sec constant, $20 \%$ output on some sonicators). Do not over heat or allow to foam excessively. Keep on ice.

6. Centrifuge the samples, and keep the supernatant for DNA quantification before processing.

7. Aliquot the supernatant $(200 \mu \mathrm{l})$ and dilute 10-fold into Dilution buffer (Upstate Biotechnologies cat. \# 20-153).

8. Pre-clear each sample twice with $80 \mu \mathrm{l}$ of ssDNA/protein A agarose beads from Upstate Biotechnologies (cat. \# 16-157).

9. Incubate samples with the indicated antibody overnight at $4{ }^{\circ} \mathrm{C}$ with constant rotation.

10. The next morning add $60 \mu \mathrm{l}$ of beads and incubate for 1 hour. Centrifuge and wash the beads once at room temperature with constant rotation with each of the following buffers (Note: You can make these buffers, see Upstate recipe, but I find that the beads are cleaner when these products are used): $1.0 \mathrm{ml}$ High Salt Solution (Upstate Biotechnologies cat. \# 20-155), $1.0 \mathrm{ml}$ Low Salt buffer Solution (Upstate Biotechnologies cat. \# 20-154), $1.0 \mathrm{ml} \mathrm{LiCl} \mathrm{Solution} \mathrm{(Upstate} \mathrm{Biotechnologies} \mathrm{cat.} \mathrm{\#} \mathrm{20-156).} \mathrm{After} \mathrm{the} \mathrm{last} \mathrm{wash,} \mathrm{the} \mathrm{beads} \mathrm{are}$ washed three times with $1 \mathrm{X} \mathrm{TE}, \mathrm{pH} 8.0$, which makes the beads slightly translucent.

11. Prepare and add fresh elution buffer (1\%SDS and $0.1 \mathrm{M} \mathrm{NaHCO} 3 ; 250 \mu \mathrm{l})$ to the beads at room temperature with constant agitation. Keep the supernatant and repeat this step once more.

12. Reverse the elution with $0.2 \mathrm{M} \mathrm{NaCl}$ for 4 hours at $65^{\circ} \mathrm{C}$.

13. Treat the samples with proteinase $\mathrm{K}(10 \mu \mathrm{l} 0.5 \mathrm{M}$ EDTA, $20 \mu \mathrm{l} 1 \mathrm{M}$ Tris-HCl, pH 6.5 , and $2 \mu \mathrm{l} 10 \mathrm{mg} / \mathrm{ml}$ proteinase $\mathrm{K}$ ) for 1 hour at $45^{\circ} \mathrm{C}$ and then extract with phenol:chloroform:isoamyl alcohol.

14. Precipitate the extracted solution with $20 \mu \mathrm{g}$ of yeast tRNA, and resuspend each sample in $50 \mu \mathrm{l}$ warm $10 \mathrm{mM}$ Tris-HCl, $\mathrm{pH}$ 8.0. The samples are now ready for PCR reactions.

\section{Specific methods in C. elegans cell biology}

\subsection{Endocytosis}

Endocytosis has been studied in two cell types in C. elegans: coelomocytes, and oocytes (Fares and Greenwald, 2001; Grant and Hirsh, 1999). Coelomocyte endocytosis is usually assayed by uptake of proteins conjugated to dyes that are injected into the body cavity. Oocyte endocytosis is measured by uptake of GFP-tagged yolk protein secreted by the intestine. Below are protocols for both assays.

\section{Protocol 19: Pulse-chase analysis of coelomocyte endocytosis (Miyuki Sato and Barth Grant)}

1. Mount adult worms under oil on a dried agarose pad as standard for microinjection.

2. Microinject Texas Red conjugated-BSA (Sigma; 0.2 to $1 \mathrm{mg} / \mathrm{ml}$ in Egg buffer) into the body cavity. Insert a needle into the body cavity in the pharyngeal region. You should see liquid flowing in the body cavity. 
3. Recover worms onto seeded plates with Egg buffer and incubate for appropriate time. In wild type, Texas Red-BSA reaches lysosomes within 60 min.

4. After incubation, mount worms on ice-chilled agarose pads ( $2 \%$ agarose) with $1 \%$ formaldehyde to stop trafficking of Texas Red-BSA. Incubate slides on ice for at least $20 \mathrm{~min}$. and observe under microscope. Slides are kept on ice until just before starting observation.

Usually, about 10 worms are injected for each time point. At early time points it is difficult to find labeled coelomocytes because the TR-BSA signal in coelomocytes is weak compared to Texas Red-BSA fluorescence in the body cavity. Using transgenic worms expressing GFP fusions of endocytic markers in coelomocytes helps to find coelomocytes.

\section{Protocol 20: Gonad/Intestine Immunostaining (Adapted From R. Francis, Schedl Lab and Sarah Crittenden, Kimble Lab by Barth Grant)}

1. Pick adults and/or L4s to an unseeded NGM plate. Alternatively, wash worms off a seeded plate with $1.5 \mathrm{ml}$ of egg buffer and spin down in an eppendorf tube, then wash once with $1.5 \mathrm{ml}$ of egg buffer. Transfer as many worms as can be dissected in $15 \mathrm{~min}(\sim 200)$. If preparing multiple batches of dissected gonads/intestines, hatch bleached eggs in M9 buffer, then aliquot them to plates to grow up as a synchronized population (about 200 worms/plate). L1 progeny of these worms present during dissection do not interfere with anything.

2. Suspend washed worms from one plate in $0.2-0.3 \mathrm{ml}$ of egg buffer $+0.2 \mathrm{mM}$ levamisole and transfer to a glass dish. Depression slides work well. Use the deepest you can find.

3. As paralysis sets in, begin cutting off heads at level of the pharynx. To cut off the head, place the head between two 25 gauge syringe needles and decapitate by moving needles in a scissors motion (avoid needles with bent tips). For most animals, at least one gonad arm and the intestine should extrude completely.

4. Transfer cut worms with a $100 \mathrm{ul}$ mouth pipette to a presiliconized $1.7 \mathrm{ml}$ eppendorf tube.

5. Fix the cut worms by adding $1 \mathrm{ml}$ of $1.25 \%$ freshly made paraformaldehyde in egg buffer. Rock at RT for 10 min. Some people post fix in $-20^{\circ} \mathrm{C}$ methanol for $5 \mathrm{~min}$. Cut worms can be stored up to two weeks in $-20^{\circ} \mathrm{C}$ methanol. GFP autofluorescence survives the aldehyde fix well, but probably not the methanol.

6. Preincubate in $1 \mathrm{ml}$ PTB at RT for at least one hour. Change buffer at least $2 \mathrm{X}$. Cut worms are spun down for $30 \mathrm{sec}$ to $1 \mathrm{~min}$ at $4,000 \mathrm{rpm}$ between buffer changes. Worms can be stored at $4{ }^{\circ} \mathrm{C}$ for a few days in PTB. The Tween20 in PTB appears to very quickly abolish fluorescence of autofluorecent gut granules (lipofucin), but has no effect on GFP.

7. Spin down cut worms, remove supernatant, add primary Ab diluted in PTB. Incubate 4 hours at RT or overnight at $4^{\circ} \mathrm{C}$ with rocking.

8. Wash for 1-4 hours at RT in PTC (four buffer changes, $1 \mathrm{ml}$ each).

9. Preincubate in PTB (+ optional 10\% serum) at RT for 30 min. Incubate in secondary antibody diluted in PTB for at least two hours at RT. Use 1:500 dilutions of Cy3 or Alexa 488 conjugated antibodies from Jackson Immunoresearch or Molecular Probes.

10. Wash for 1-4 hours at RT in PTC (four buffer changes, $1 \mathrm{ml}$ each). You can never wash too much. An extra overnight wash at $4^{\circ} \mathrm{C}$ can give nice results.

11. Spin down cut worms, remove supernatant, resuspend in a glycerol antifade reagent such as Slowfade Light from Molecular Probes. Store at $-20^{\circ} \mathrm{C}$. Mount on pads of Permanent Springtime Agarose just before viewing. Can seal with nail polish. Slides don't last long, but can be stored briefly at $4^{\circ} \mathrm{C}$. 


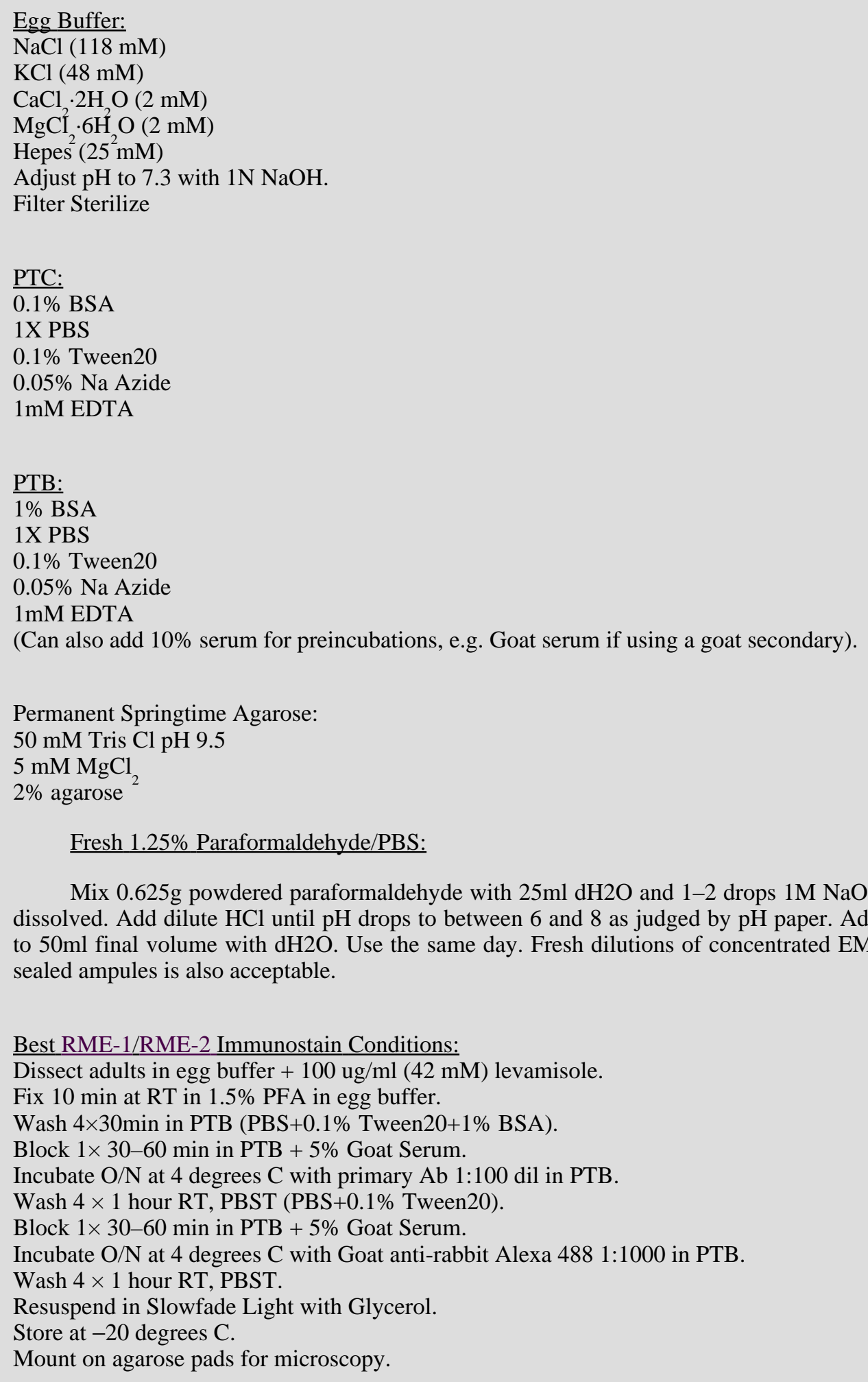

\section{Fresh $1.25 \%$ Paraformaldehyde/PBS:} sealed ampules is also acceptable.

\section{Best RME-1/RME-2 Immunostain Conditions:}

Dissect adults in egg buffer $+100 \mathrm{ug} / \mathrm{ml}(42 \mathrm{mM})$ levamisole.

Fix $10 \mathrm{~min}$ at RT in $1.5 \%$ PFA in egg buffer.

Wash $4 \times 30 \mathrm{~min}$ in PTB (PBS+0.1\% Tween $20+1 \%$ BSA).

Block $1 \times 30-60 \mathrm{~min}$ in PTB $+5 \%$ Goat Serum.

Incubate $\mathrm{O} / \mathrm{N}$ at 4 degrees $\mathrm{C}$ with primary $\mathrm{Ab} 1: 100$ dil in $\mathrm{PTB}$.

Wash $4 \times 1$ hour RT, PBST (PBS+0.1\% Tween 20 ).

Block $1 \times 30-60$ min in PTB $+5 \%$ Goat Serum.

Incubate $\mathrm{O} / \mathrm{N}$ at 4 degrees $\mathrm{C}$ with Goat anti-rabbit Alexa 488 1:1000 in PTB.

Wash $4 \times 1$ hour RT, PBST.

Resuspend in Slowfade Light with Glycerol.

Store at -20 degrees $\mathrm{C}$.

Mount on agarose pads for microscopy.

Mix $0.625 \mathrm{~g}$ powdered paraformaldehyde with $25 \mathrm{ml} \mathrm{dH} 2 \mathrm{O}$ and $1-2$ drops $1 \mathrm{M} \mathrm{NaOH}$. Heat to $65^{\circ} \mathrm{C}$. Mix until dissolved. Add dilute $\mathrm{HCl}$ until $\mathrm{pH}$ drops to between 6 and 8 as judged by $\mathrm{pH}$ paper. Add $5 \mathrm{ml}$ 10X PBS. Bring up to $50 \mathrm{ml}$ final volume with $\mathrm{dH} 2 \mathrm{O}$. Use the same day. Fresh dilutions of concentrated EM grade formaldehyde from 


\subsection{Chromatin cell biology (Györgyi Csankovszki and Barbara Meyer)}

Specific chromosomal sequences, as well as chromosome-associated proteins can be elegantly labeled in $C$. elegans using immunofluorescence and fluorescence in situ hybridization (FISH) (Figure 12). In general, signals are easier to detect and resolve in larger nuclei, thus, best results are obtained by looking at germ cells, intestinal cells, and cells in the early embryo. A variety of protocols related to chromatin visualization are presented below.

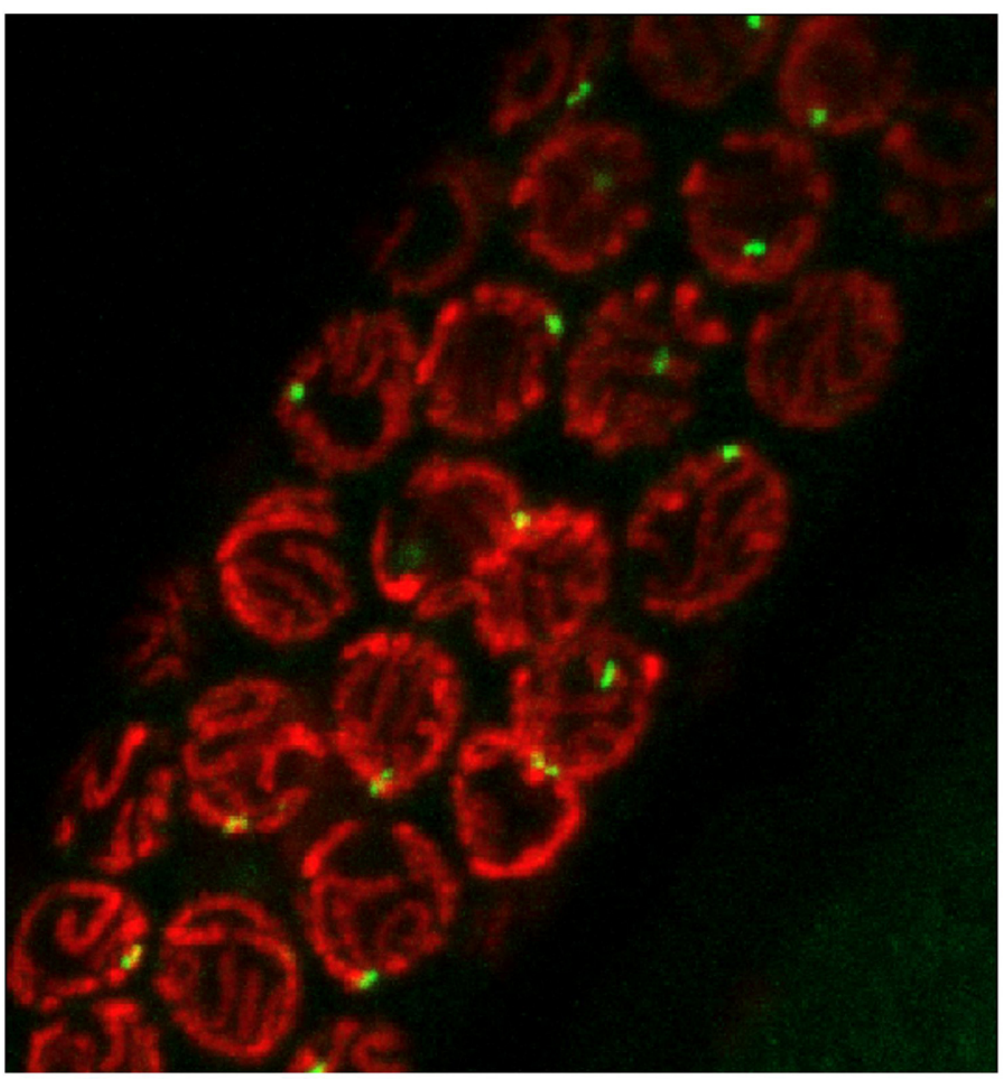

Figure 12. Pachetene stage germ cells stained using FISH. Red, DAPI; Green, 5S rDNA FISH (Annette Chan and Barbara Meyer).

\section{Protocol 21: Antibody staining of C. elegans gonads (Annette Chan and Barbara Meyer)}

1. Use $1 \%, 1.5 \%$, and $2 \%$ PFA with 5-minute fix:

a. Place worms in $5 \mu \mathrm{l} 1 \mathrm{X}$ sperm salts on a positively-charged glass slide.

b. Using a needle (Precision Glide ${ }^{\circledR}$ Needle, Becton Dickinson \& Co., 22 G 1 1/2), make an incision between the pharynx and gonad (closer to the gonad than the pharynx) or between the tip of the tail and gonad of each worm. To release the embryos, cut at the vulva.

c. Add $5 \mu \mathrm{l}$ of $2 \%, 3 \%$, or 4\% PFA (Electron Microscopy Sciences, cat. \#15710) in 1X sperm salts.

To prepare 2\% PFA:
$125 \mu \mathrm{l} 16 \%$ PFA

$200 \mu \mathrm{l} 5 \mathrm{X}$ sperm salts

$675 \mu \mathrm{l}$ water 


\begin{tabular}{|l|l|}
\hline To prepare 3\% PFA: & $187.5 \mu \mathrm{l} 16 \%$ PFA \\
& $200 \mu \mathrm{l} 5 \mathrm{X}$ sperm salts \\
& $612.5 \mu \mathrm{l}$ water \\
\hline
\end{tabular}

\begin{tabular}{|l|l|}
\hline To prepare 4\% PFA: & $250 \mu \mathrm{l} 16 \%$ PFA \\
& $200 \mu \mathrm{l}$ 5X sperm salts \\
& $550 \mu \mathrm{l}$ water \\
\hline
\end{tabular}

d. Place the slide in a humid chamber for 5 minutes. Place an 18 - $\mathrm{mm} \times 18$-mm cover glass on top of the worms. Freeze the slide on a piece of dry ice. Let the slide sit on the dry ice for at least 10 minutes.

2. Remove the slide from the dry ice and quickly pop off the cover glass with a quick downward stroke of a single-edged razor.

3. Immediately place the slide in $95 \%$ ethanol for 1 minute. Be careful or the worms will fall off.

4. Incubate the slide in a vessel containing PBST for at least 10 minutes. Repeat this step twice.

5. Wick off most of the PBST, but do not allow the worms to dry. Add 20 to $30 \mu$ primary antibody diluted in PBST. Carefully cover the worms with a $20 \times 20-\mathrm{mm}$ piece of parafilm. Place the slide in a humid chamber. Incubate overnight at room temperature.

6. Incubate the slide in a vessel containing PBST for at least 10 minutes. Carefully remove the piece of parafilm.

7. Incubate the slide in a vessel containing fresh PBST for at least 10 minutes. Repeat this step once.

8. Wick off most of the PBST, but do not allow the worms to dry. Add 20 to $30 \mu$ secondary antibody diluted in PBST. Carefully cover the worms with a $20 \times 20-\mathrm{mm}$ piece of parafilm. Place the slide in a humid chamber. Incubate overnight at room temperature. Keep the slides in the dark whenever possible.

9. Incubate the slide in a vessel containing PBST for at least 10 minutes. Carefully remove the piece of parafilm.

10. Incubate the slide in a vessel containing fresh PBST for at least 10 minutes. Repeat this step once.

11. Wick off most of the PBST, but do not allow the worms to dry. Add $10 \mu \mathrm{lof} 1 \mu \mathrm{g} / \mathrm{ml}$ DAPI or $1 \mu \mathrm{g} / \mathrm{ml}$ propidium iodide to the slide.

12. Mount the slide with $20 \mu \mathrm{l}$ anti-fade solution and a $22 \times 40$-mm cover glass. Seal the slide with fingernail polish.

13. Observe the slide. Store the slides at $-20^{\circ} \mathrm{C}$. Keep the slides in the dark whenever possible.

\section{Buffers/reagents}

\begin{tabular}{|l|l|}
\hline Sperm Salts: & $50 \mathrm{mM}$ PIPES, pH 7.0 \\
& $25 \mathrm{mM} \mathrm{KCl}$ \\
& $1 \mathrm{mM} \mathrm{MgSO}_{4}$ \\
& $45 \mathrm{mM} \mathrm{NaCl}$ \\
& $2 \mathrm{mM} \mathrm{CaCl}_{2}$ \\
\hline
\end{tabular}




\begin{tabular}{|l|l}
\hline PBST: & $10 \mathrm{ml} 10 \mathrm{X}$ PBS \\
& $2.5 \mathrm{ml} 20 \%$ Triton X-100 \\
& $0.2 \mathrm{ml} 0.5 \mathrm{M}$ EDTA, pH 8 \\
& $87.3 \mathrm{mlddH}_{2} \mathrm{O}$ \\
\hline
\end{tabular}

\begin{tabular}{|l|l|}
\hline DABCO: & $50 \mathrm{ml}$ total \\
$5 \mathrm{~g} \mathrm{DABCO}$ & \\
$5 \mathrm{ml}$ PBS & \\
$45 \mathrm{ml}$ glycerin & \\
\hline
\end{tabular}

Notes:

When trying an antibody for the first time, it is often good to try all three fixative concentrations for 5 minutes each (Step \#1). This gives you a baseline for adjusting the protocol for your specific antibody. You might notice certain trends. For example, when you use lower fixative concentrations, you might find that the antibody staining becomes brighter, but the structure of the chromosomes becomes worse. As you use higher fixative concentrations, the antibody staining might be worse (dimmer, penetration not as good), but the structure might be better. If this is the case and you need the chromosomes to have better structure, you might try incubating in a lower fixative concentration for a longer time period or in a higher fixative concentration for less time. If penetration is not good with the lowest fixative concentration that you tried, you might try an even lower concentration, or you might try less time in the lower fixative concentration (e.g., 2 minutes, instead of 5 minutes). You can try higher concentrations of the PFA and longer incubation times in the PFA for better structure.

The fixative concentration, fixation time, and freeze-cracking step (Step \#2) are very important. You can see great differences in staining with small changes in fixative concentration and fixation time, and it is important to get a good freeze-crack.

You can tell that the penetration of the antibody was not good when nothing stains or just the outer surface or outer layer of cells stains.

If you see that worms on one part of a slide stain but worms on another part do not stain, you may be having freeze-cracking problems (Step \#2).

If you leave the slides on the dry ice for too long (Step \#1d), the slides can get icy, and you might not get a good freeze-crack (Step \#2).

For a new antibody, try a concentration gradient with the antibody. The staining is sometimes greatly improved with lower concentrations of some antibodies.

Removing the ethanol step (Step \#3) can produce dramatic changes in the antibody staining. It is good to try the protocol with and without the ethanol step. Ethanol is a coagulating fixative that denatures proteins and changes the protoplasm into an artificially interconnected network. A short dip in ethanol can coagulate proteins and boost signal, but it might also increase "background." Ethanol can also cause signal to "disappear" in some cases.

This protocol does not have any block. First, try a new antibody without block to see everything that the antibody sticks to without block. Then you can try adding block, such as BSA or fish gelatin (Cold Water Fish Skin Gelatin 40\%, catalog \#25560, Electron Microscopy Sciences). You might find that block is not needed or that block causes greater background staining rather than lower background staining.

The "humid chamber" can be any container that can be sealed with wet paper towels inside.

Swirl the slide around a little after adding the fixative in Step 1c. You can place the cover glass on the slide 
shortly after mixing the fixative and the sperm salt solution together in Step 1d. This can help to get the worms to stick to the slides better.

The incubation times with both the primary and the secondary antibodies can often be less. For example, you can try incubating in secondary antibody for four hours at room temperature.

Several different anti-fade solutions can be used, e.g., VECTASHIELD, ProLong, and DABCO. DABCO does not work well with Cy5. It may not be good to use DABCO with any of the Cy dyes; however, I have not had a problem with DABCO and Cy3.

You can use smaller cover glasses. Just use less DNA stain and anti-fade solution.

People often get variable results when they first use this protocol. Some slides have good antibody staining, and some do not. This may be because they are still learning the technique. For example, if you dissect the worms too slowly in Step 1b, sperm salt solution will evaporate, changing the final fixative concentration. As you get better and better at dissecting the worms, the final fixative concentration is closer to the desired concentration, and the antibody staining becomes more consistent.

You can add levamisole or sodium azide to help you to immobilize the worms before dissecting them, but be careful with how these chemicals might affect structure.

This protocol was originally designed to look at worm gonads, but it was found to work with gut nuclei as well. To look at structures other than gonads, you may need to adjust the protocol. For example, egg buffer might be better for embryos. This protocol was not designed for embryo staining, although embryos do sometimes stain with antibody with this procedure. Often few embryos stain, and the condition of the embryos is not good. Embryos often do not stick to the slides well with this protocol and fall off during the procedure. Using $-20^{\circ} \mathrm{C} 95 \%$ ethanol, instead of room temperature 95\% ethanol, in Step \#3 might help with this problem. You could also try omitting the ethanol step.

\section{Protocol 22: Observing chromosomes in dissected worms (Annette Chan and Barbara Meyer)}

1. Use $2 \%$ PFA with 5-minute fix:

a. Place worms in $5 \mu \mathrm{l} 1 \mathrm{X}$ sperm salts on a positively-charged glass slide.

b. Using a needle (Precision Glide ${ }^{\circledR}$ Needle, Becton Dickinson \& Co., 22 G 1 1/2), make an incision between the pharynx and gonad (closer to the gonad than the pharynx) or between the tip of the tail and gonad of each worm. To release the embryos, cut at the vulva.

c. Add $5 \mu$ of $4 \%$ PFA (Electron Microscopy Sciences, cat. \#15710) in $1 \mathrm{X}$ sperm salts.
To prepare $4 \%$ PFA:
$250 \mu \mathrm{l} 16 \%$ PFA
$200 \mu \mathrm{l} 5 \mathrm{X}$ sperm salts
$550 \mu \mathrm{l}$ water

d. Place the slide in a humid chamber for 5 minutes. Place an 18 - $\mathrm{mm} \times 18$ - $\mathrm{mm}$ cover glass on top of the worms. Freeze the slide on a piece of dry ice. Let the slide sit on the dry ice for at least 10 minutes.

2. Remove the slide from the dry ice and quickly pop off the cover glass with a quick downward stroke of a single-edged razor.

3. Immediately place the slide in $95 \%$ ethanol for 1 minute. Be careful or the worms will fall off. 
4. Incubate the slide in a vessel containing PBST for at least 10 minutes. Repeat this step twice.

5. Wick off most of the PBST, but do not allow the worms to dry. Add $10 \mu \mathrm{lof} 1 \mu \mathrm{g} / \mathrm{ml}$ DAPI or propidium iodide to the slide.

6. Mount the slide with $20 \mu \mathrm{l}$ anti-fade solution and a $22 \times 40$-mm cover glass. Seal the slide with fingernail polish.

7. Observe the slide. Store the slides at $-20^{\circ} \mathrm{C}$. Keep the slides in the dark whenever possible.

Solutions/Reagents

\begin{tabular}{|l|l|}
\hline Sperm Salts: & $50 \mathrm{mM} \mathrm{PIPES}, \mathrm{pH} 7.0$ \\
& $25 \mathrm{mM} \mathrm{KCl}$ \\
& $1 \mathrm{mM} \mathrm{MgSO}_{4}$ \\
& $45 \mathrm{mM} \mathrm{NaCl}$ \\
& $2 \mathrm{mM} \mathrm{CaCl}_{2}$ \\
\hline
\end{tabular}

\begin{tabular}{|l|l}
\hline PBST: & $10 \mathrm{ml} \mathrm{10X} \mathrm{PBS}$ \\
& $2.5 \mathrm{ml} \mathrm{20 \%} \mathrm{Triton} \mathrm{X-100}$ \\
& $0.2 \mathrm{ml} \mathrm{0.5} \mathrm{M} \mathrm{EDTA,} \mathrm{pH} \mathrm{8}$ \\
& $87.3 \mathrm{ml} \mathrm{ddH}_{2} \mathrm{O}$ \\
\hline
\end{tabular}

\begin{tabular}{|l|l|}
\hline DABCO: & $50 \mathrm{ml}$ total \\
5 g DABCO & \\
$5 \mathrm{ml} \mathrm{PBS}$ & \\
$45 \mathrm{ml}$ glycerin & \\
\hline
\end{tabular}

\section{Notes:}

You can try higher concentrations of the PFA and longer incubation times in the PFA for better structure.

Several different anti-fade solutions can be used, e.g., VECTASHIELD, ProLong, and DABCO.

You can use smaller cover glasses. Just use less DAPI and anti-fade solution.

This protocol works well with the gonad and the gut. Embryos often don't stick to the slides well with this protocol and fall off during the procedure. Using $-20^{\circ} \mathrm{C} 95 \%$ ethanol, instead of room temperature $95 \%$ ethanol, in Step \#3 might help with this problem. You could also try omitting the ethanol step.

Protocol 23: Observing chromosomes in whole worms using Streck tissue fixative (Annette Chan and Barbara Meyer)

1. Pick several worms and place them in $200 \mu$ l Streck Tissue Fixative (S.T.F., Streck Laboratories, Inc., catalog 
\#265180) in a glass-welled plate.

2. Incubate worms in the fixative overnight at room temperature in a humid chamber.

3. Carefully remove the fixative from the glass-welled plate with a tip for a 1-200 ul pipettor. Add about $200 \mu \mathrm{l}$ PBS. Rinse the worms. Repeat this wash step until the wash solution is clear.

4. Remove the PBS and add about $200 \mu 195 \%$ ethanol. Let sit for 1 minute. Swirl the worms around to get them to sink to the bottom of the well.

5. Remove the ethanol and add $200 \mu \mathrm{l}$ PBS. Rinse the worms. Repeat this wash step at least twice.

6. Make sure the worms sink to the bottom of the well before attempting to pick them up. Place the worms on a positively-charged glass slide using a glass Pasteur pipette. Wick away the liquid, but do not allow the worms to dry.

7. Add $10 \mu \mathrm{l}$ of $1 \mu \mathrm{g} / \mathrm{ml}$ DAPI to the slide.

8. Mount the slide with $10 \mu \mathrm{l}$ anti-fade solution and a $22 \times 40$-mm cover glass. Seal slide with fingernail polish.

9. Observe the slide. Store at $-20^{\circ} \mathrm{C}$.

Notes:

Avoid pipetting the worms into the tip because they tend to stick to plastic

For Step \#4, it can be hard to remove all of the PBS and then add ethanol. If this is the case, remove as much PBS as possible in Step \#4, and then add ethanol. Swirl the ethanol/PBS mixture around a little. Remove as much liquid as possible, and then add fresh 95\% ethanol. Now, let the worms sit for 1 minute.

Worms are often lost during Step \#6 while trying to wick away liquid. If this is a problem, instead of doing Steps \#6 to \#8, put DAPI and anti-fade solution on a slide, pick worms into the DAPI and anti-fade solution, mount the slide with a cover glass, and then seal the slide with fingernail polish. You can also put DAPI on a slide, pick worms into the DAPI, add anti-fade solution, swirl a little, mount the slide with a cover glass, and then seal the slide with fingernail polish.

Several different anti-fade solutions can be used, e.g., VECTASHIELD, ProLong, and DABCO.

You can use smaller cover glasses. Just use less DAPI and anti-fade solution.

Protocol 24: Observing chromosomes in whole worms using paraformaldehyde (Annette Chan and Barbara Meyer)

1. Pick several worms and place them in $200 \mu \mathrm{l} 8 \%$ PFA (Electron Microscopy Sciences, cat. \#15710) in a glass-welled plate.

\section{To prepare $8 \%$ PFA:}

$$
\begin{aligned}
& 100 \mu \mathrm{l} 16 \% \text { PFA } \\
& 10 \mu \mathrm{l} \text { 20X M9 buffer } \\
& 90 \mu \text { l water }
\end{aligned}
$$

2. Incubate worms in the fixative for 1 hour at room temperature in a humid chamber. 
3. Carefully remove the fixative from the glass-welled plate with a tip for a 1-200 ul pipettor. Add about $200 \mu \mathrm{l}$ PBS. Rinse the worms. Repeat this wash step until the wash solution is clear.

4. Remove the PBS and add about $200 \mu 195 \%$ ethanol. Let sit for 1 minute. Swirl the worms around to get them to sink to the bottom of the well.

5. Remove the ethanol and add $200 \mu \mathrm{l}$ PBS. Rinse the worms. Repeat this wash step twice.

6. Make sure the worms sink to the bottom of the well before attempting to pick them up. Place the worms on a positively-charged glass slide using a glass Pasteur pipette. Wick away the liquid, but do not allow the worms to dry.

7. Add $10 \mu \mathrm{l}$ of $1 \mu \mathrm{g} / \mathrm{ml}$ DAPI to the slide.

8. Mount the slide with $10 \mu \mathrm{l}$ anti-fade solution and a $22 \times 40$-mm cover glass. Seal slide with fingernail polish.

9. Observe the slide. Store at $-20^{\circ} \mathrm{C}$.

Notes:

Avoid pipetting the worms into the tip because they tend to stick to plastic.

For Step \#4, it can be hard to remove all of the PBS and then add ethanol. If this is the case, remove as much PBS as possible in Step \#4, and then add ethanol. Swirl the ethanol/PBS mixture around a little. Remove as much liquid as possible, and then add fresh 95\% ethanol. Now, let the worms sit for 1 minute.

Worms are often lost during Step \#6 while trying to wick away liquid. If this is a problem, instead of doing Steps \#6 to \#8, put DAPI and anti-fade solution on a slide, pick worms into the DAPI and anti-fade solution, mount the slide with a cover glass, and then seal the slide with fingernail polish. You can also put DAPI on a slide, pick worms into the DAPI, add anti-fade solution, swirl a little, mount the slide with a cover glass, and then seal the slide with fingernail polish.

Several different anti-fade solutions can be used, e.g., VECTASHIELD, ProLong, and DABCO.

You can use smaller cover glasses. Just use less DAPI and anti-fade solution.

Protocol 25: DNA FISH and DNA FISH followed by Immunofluorescence (Györgyi Csankovszki and Barbara Meyer)

\section{Preparation of FISH probe.}

1. Label probe by nick translation or random priming using fluorescent nucleotides, such as cy3-dCTP, cy5-dCTP (Amersham), or fluorescein-dUTP (Roche).

2. Remove unincorporated nucleotides using a spin column.

3. Ethanol precipitate probe together with $40 \mu \mathrm{L}$ salmon sperm DNA $(10 \mathrm{mg} / \mathrm{mL})$.

4. Wash pellet in $70 \%$ ethanol, and dry well (air dry or speed vac).

5. Resuspend pellet in $160 \mu \mathrm{L}$ formamide.

6. Denature probe at $70-74^{\circ} \mathrm{C}, 10$ minutes.

7. Chill on ice. 
8. Add $160 \mu \mathrm{L} 2 \mathrm{X}$ hyb (1 part 20X SSC, 2 parts $10 \mathrm{mg} / \mathrm{mL}$ BSA, 2 parts $50 \%$ dextran sulfate)

9. The probe is ready to use as is and can be stored at $-20^{\circ} \mathrm{C}$ for months.

\section{Fixation of worms for staining the gut or the germline.}

1. Pick about 40 animals onto a drop $(5 \mu \mathrm{L})$ of sperm salts $(50 \mathrm{mM}$ PIPES pH7, $25 \mathrm{mM} \mathrm{KCl}, 1 \mathrm{mM} \mathrm{MgSO}, 45$ $\mathrm{mM} \mathrm{NaCl}, 2 \mathrm{mM} \mathrm{CaCl}$ ) on a microscope slide. Cut to release gonads and gut. Add $5 \mu \mathrm{L}$ of fixative (2-4\% PFA in sperm salts) and fix for 5 minutes in a humid chamber.

2. Place an $18 \times 18 \mathrm{~mm}$ coverslip on worms and place the slide on a dry ice block for 10 minutes.

3. Remove coverslip with a single-edged razor blade and immediately place the slide in PBST $(1 \times$ PBS, I mM EDTA, $0.5 \%$ Triton X-100) at RT in a coplin jar.

4. Wash slides in PBST $3 \times 10$ minutes.

5. Place slides in $70 \%$ ethanol for 2 minutes.

6. $80 \%$ ethanol for 2 minutes, $95 \%$ ethanol for 2 minutes, $100 \%$ ethanol for 2 minutes.

7. Air dry. Proceed with FISH.

\section{Fixation of embryos.}

1. Bleach gravid hermaphrodites, wash and pellet embryos using standard methods.

2. Add and equal volume of fixative ( $4 \%$ PFA, $1 \times$ sperm salts) to the embryo pellet.

3. Pipette $10 \mu \mathrm{L}$ of embryos to each slide and cover with an $18 \mathrm{~mm} \times 18 \mathrm{~mm}$ coverslip. Incubate in humid chamber for a total of 5 minutes from the time fixative was added in step 2.

4. Place slides on a block of dry ice for 10 minutes.

5. Using a razor blade, remove coverslip and immerse slides in RT PBST.

6. Wash slides in PBST 3 times, 10 minutes. Handle slides carefully, otherwise embryos will fall off.

7. Place slides in $70 \%$ ethanol for 2 minutes.

8. $80 \%$ ethanol for 2 minutes, $95 \%$ ethanol for 2 minutes, $100 \%$ ethanol for 2 minutes.

9. Air dry. Proceed with FISH.

\section{$\underline{\text { FISH }}$}

1. Add $10-20 \mu \mathrm{L}$ of FISH probe and cover with coverslip.

2. Place slide on a $95^{\circ} \mathrm{C}$ heat block for 3 minutes to denature the sample.

3. Incubate in humid chamber at $37^{\circ} \mathrm{C}$ overnight.

4. Wash slide in $2 \mathrm{X} \mathrm{SSC} / 50 \%$ formamide, 5 minutes at $39^{\circ} \mathrm{C}, 3$ times.

5. Wash in $2 \mathrm{X} \mathrm{SSC}, 5$ minutes at $39^{\circ} \mathrm{C}, 3$ times.

6. Wash in $1 \mathrm{X} \mathrm{SSC}, 10$ minutes at $39^{\circ} \mathrm{C}$, once.

7. For immunofluorescence, proceed to the next section, otherwise wash slides once more in $4 \mathrm{X} \mathrm{SSC} / 0.01 \mu \mathrm{g} / \mathrm{mL}$ 
DAPI. Mount the slides using Vectashield (Vector Labs) and store them at $-20^{\circ} \mathrm{C}$.

Immunofluorescence.

(This part follows the Meyer lab staining protocol developed by Annette Chan.)

1. Wash slides in PBST.

2. Without letting the worms dry, wick off most of the PBST, add $30 \mu \mathrm{L}$ primary antibody diluted in PBST, cover sample with a small piece of parafilm. Incubate in humid chamber at RT overnight, or $37^{\circ} \mathrm{C}$ for 4 hours. (Temperature and duration of incubation is antibody dependent.)

3. Wash slides 3 times in PBST, 10 minutes each.

4. Add $30 \mu \mathrm{L}$ secondary antibody diluted in PBST, cover worms with parafilm, incubate at RT for 4 hours or $37^{\circ} \mathrm{C}$ for 1 hour in a humid chamber.

5. Wash slides 3 times in PBST, 10 minutes each. In the last wash, to $50 \mu \mathrm{L}$ of PBST add $0.5 \mu \mathrm{L}$ of $1 \mathrm{mg} / \mathrm{mL}$ DAPI to counterstain DNA.

6. Mount the slides using Vectashield, and store them at $-20^{\circ} \mathrm{C}$.

\subsection{Programmed cell death (Barbara Conradt, Julia Hatzold, Claus Schertl)}

\subsubsection{Detecting dying cells}

Dying cells can be detected by their morphology and refractility using differential interference contrast microscopy (DIC; see above; Sulston and Horvitz, 1977). A cell corpse appears as a highly refractile, button-like structure (Figure 13), which is rapidly engulfed and degraded by neighboring cells. Cell death occurs in the $C$. elegans soma mainly during embryogenesis and in the female germ line as a normal course of development (Gumienny et al., 1999). Germ-cell death can also be induced by DNA-damaging agents or by pathogenic bacteria (Aballay and Ausubel, 2001; Gartner et al., 2000). Below we present several protocols for detecting dying cells in the soma and germ line. 


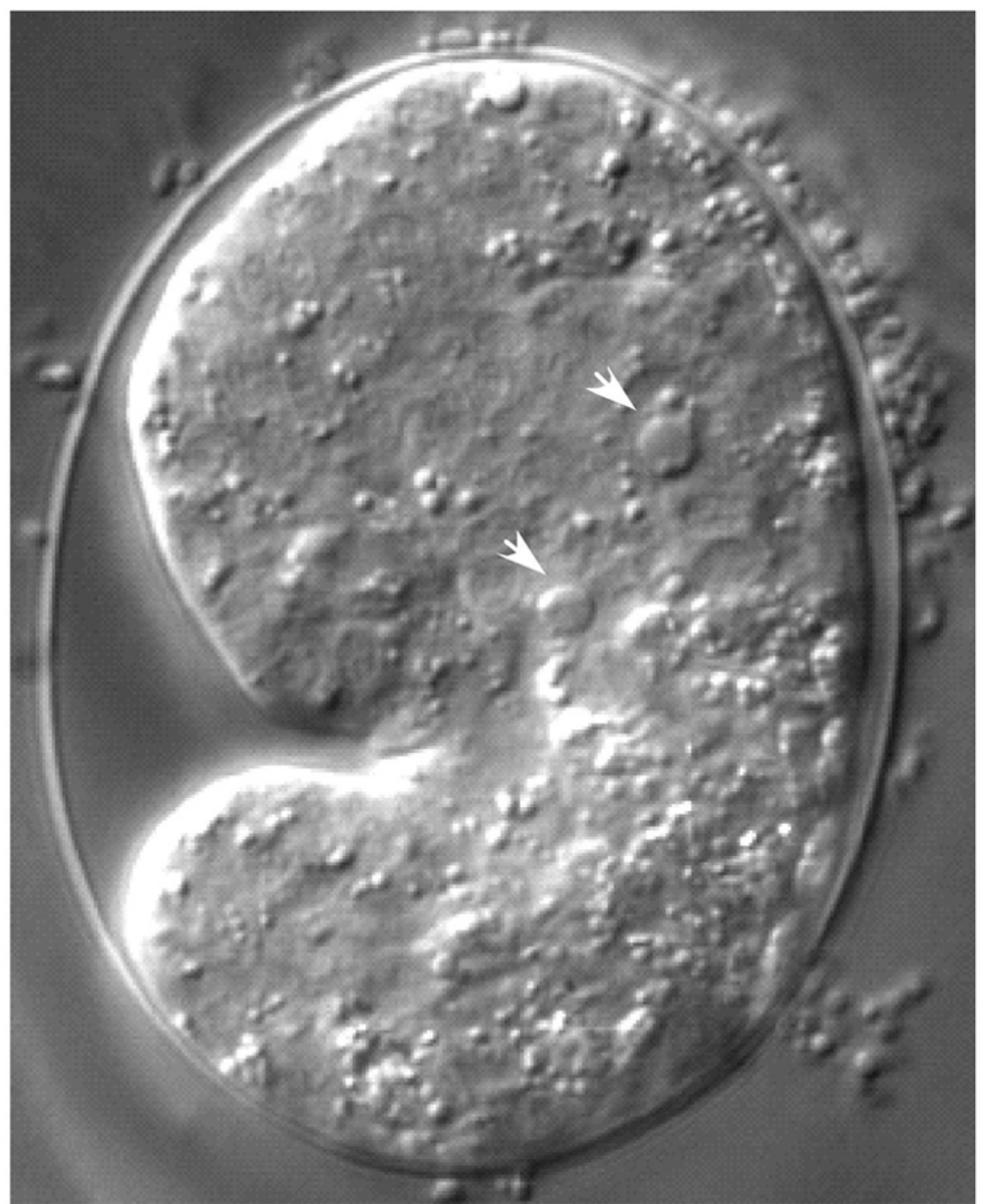

Figure 13. DIC image of wild-type embryo at comma stage of development. Arrows point to the round, button-like corpses (Julia Hatzold and Barbara Conradt).

\subsubsection{TUNEL labeling}

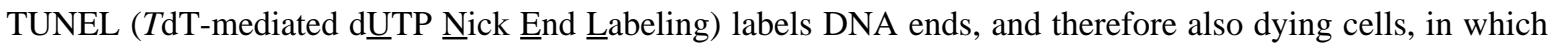
DNA becomes degraded (Gavrieli et al., 1992). TUNEL can be used as a marker for dying cells and to analyze DNA degradation. DNA degradation occurs very rapidly during cell death, thus, TUNEL stains apoptotic cells only during a transient stage of DNA degradation. For this reason, usually only a small subset of corpses is labeled with this technique. However, in nuc-1 mutants, which are defective in some aspects of DNA degradation, the nuclei of many dying cells can be labeled using this method (Wu et al., 2000).

\section{Protocol 26: TUNEL staining for embryos (based on Wu et al., 2000)}

Animals are washed from one to three $15-\mathrm{mm}$ petri plates with water and treated with hypochlorite to obtain the embryo.

A total of $1 \mathrm{ml}$ of fixation solution is added to the embryos, which are immediately frozen in liquid nitrogen. The frozen embryos are thawed in a water bath at room temperature for $2 \mathrm{~min}$ and rocked at room temperature for $25 \mathrm{~min}$. Fixed embryos are washed once in $1 \mathrm{ml}$ of Tris-Triton buffer and three times in $1 \mathrm{ml}$ of PBST for $10 \mathrm{~min}$ each. Approximately $3 \mu \mathrm{l}$ of packed embryos are preincubated with $25 \mu \mathrm{l}$ of TdT reaction buffer for $5 \mathrm{~min}$ at room temperature. TdT reaction buffer is then replaced with TdT reaction buffer containing 0.2 units of TdT (Boehringer Mannheim), $6.6 \mathrm{nM}$ dUTP (Boehringer Mannheim) and $3.3 \mathrm{nM}$ fluorescein-11-dUTP (Boehringer Mannheim), and incubated for $2 \mathrm{hr}$ at $37^{\circ} \mathrm{C}$. After incubation, embryos are washed in PBST three times for $10 \mathrm{~min}$. Embryos are mounted in Vectashield mounting medium (Vector Laboratories). 


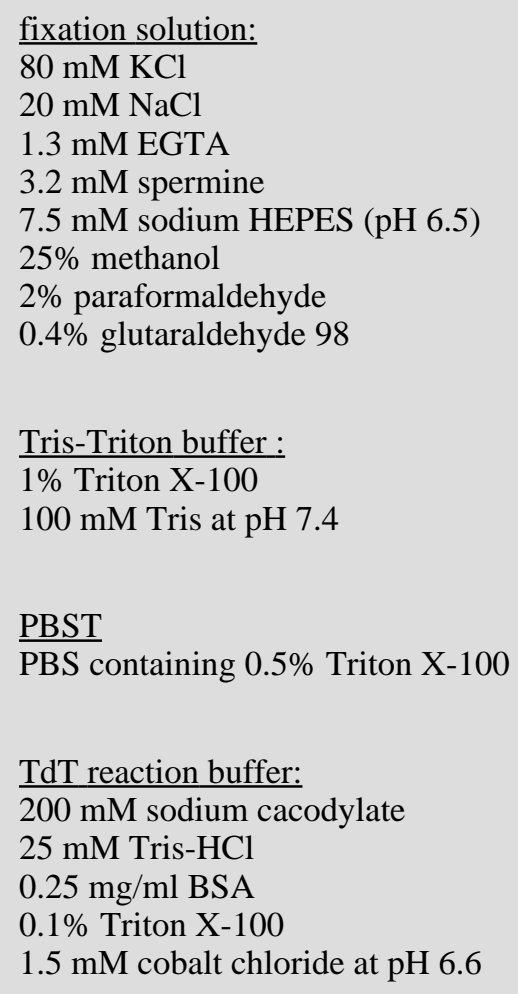

\section{Protocol 27: TUNEL labeling of dying germ cells (based on Francis et al., 1995)}

1. Pick clean worms into a drop of $180 \mu \mathrm{l}$ PBLE, in a watch glass.

2. Cut off heads using $28 \mathrm{G}$ needles.

3. Add $19 \mu \mathrm{l} 37 \%$ formaldehyde.

4. Fix for 60 minutes at room temp. in humidified chamber.

5. Remove most of liquid using a finely drawn capillary.

6. Add $500 \mu \mathrm{l}$ of $-20^{\circ} \mathrm{C} 100 \%$ methanol.

7. Fix at room temperature for 3 minutes.

8. Remove $\sim 1 / 2$ of the methanol and add $1 \mathrm{ml}$ PBS.

9. Remove most of the liquid and add $1 \mathrm{ml}$ PBS. Repeat once more.

10. Add $1 \mathrm{ml}$ PBST and then remove most of liquid (leaving $20 \mu \mathrm{l}$ ). used.

For the labeling of corpses in dissected gonads the In Situ Cell Death Detection Kit, Fluorescein (Roche) was

1. Mix $5 \mu \mathrm{l}$ of Enzyme Solution with $45 \mu \mathrm{l}$ of Label Solution (for a negative control use Label Solution only)

2. Incubate samples in this mix for 1 hour in the dark at $37^{\circ} \mathrm{C}$ 
3. Wash twice with PBS

It is possible to do an additional DAPI staining to visualize the DNA in neighboring healthy cells. Two additional washing steps that include the DAPI reagent are necessary right before the gonads are mounted on slides:

1. Remove most liquid and add $1 \mathrm{ml} \mathrm{PBST}$ and $2 \mu \mathrm{l} 100 \mu \mathrm{g} / \mathrm{ml}$ DAPI.

2. Incubate at room temperature for $10 \mathrm{~min}$

3. Transfer animals onto microscope slide

4. Remove almost all liquid using drawn capillary

5. Immediately add $10 \mu \mathrm{l}$ VECTASHIELD antifade mounting medium (Vector Laboratories, H-1000)

6. Center worms in drop and add cover glass

7. Seal with nail polish

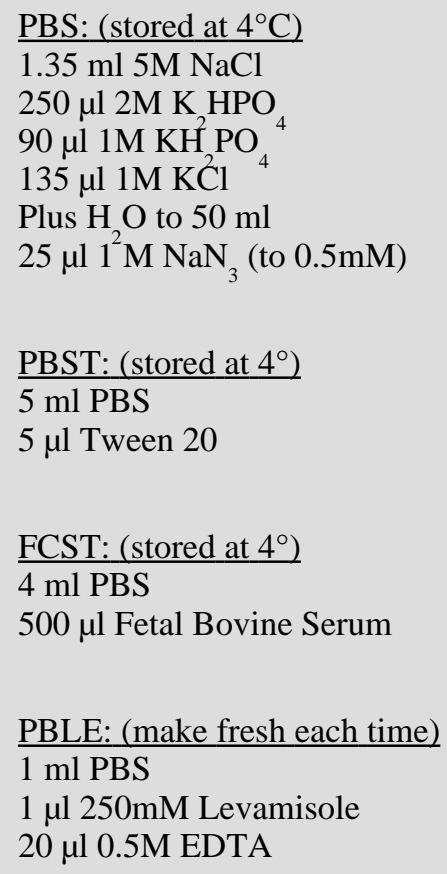

\subsubsection{SYTO dyes}

SYTO dyes (Molecular Probes) clearly label DNA in all cells. However, condensed DNA in apoptotic cells ("dead nuclei") stains more brightly than DNA in living cells. SYTO11, SYTO12, and Acridine Orange have given the best results (Gumienny et al., 1999; Wu et al., 2000; Figure 14). 

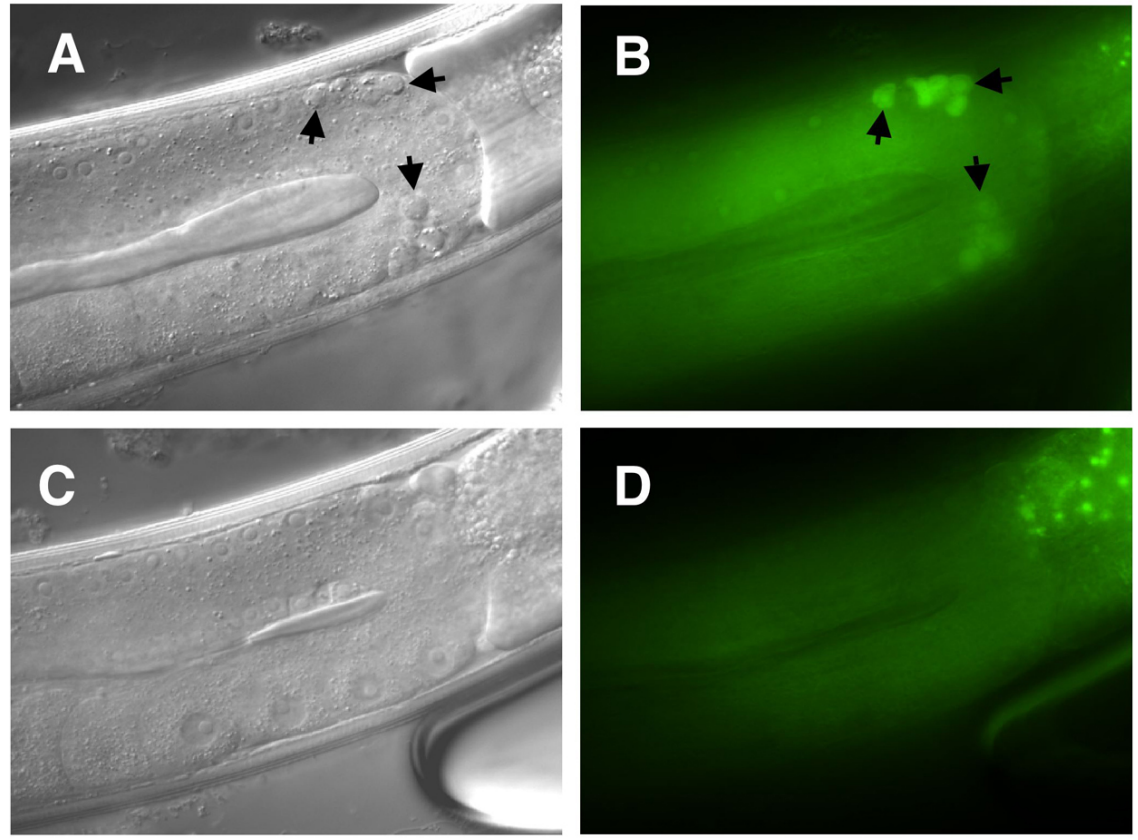

Figure 14. A. wild-type DIC view of X-ray induced germ-cell death. B. SYTO12 staining of A. C. ced-3(n717) DIC. D. SYTO12 staining of C. Arrows point at corpses (Shai Shaham).

\section{Protocol 28: SYTO11 staining of dying somatic cells (based on Wu et al., 2000)}

Worms are washed off plates with M9 solution, collected in a $1.5 \mathrm{ml}$ eppendorf tube, and washed once in M9. The washed worms are incubated with $1 \mathrm{ml}$ of $10 \mathrm{nM}$ SYTO 11 (Molecular Probes) in M9 and rocked at room temperature for $1.5 \mathrm{hrs}$. The stained worms are washed once in M9 and spotted onto a plate for recovery for at least 30 mins. Worms are mounted on $4 \%$ agar pads with $20 \mathrm{mM} \mathrm{NaN}_{3}$ and visualized using fluorescence microscopy and Nomarski optics to score cell corpses. Staining is observed with a DAPI or FITC filter set.

\section{Protocol 29: SYTO staining of dying germ cells (based on Gumienny et al., 1999)}

SYTO dyes (Molecular Probes) stain DNA in the nucleus of all cells. Staining in apoptotic cells is usually much brighter as the DNA is more condensed in these cells. A good signal to noise ratio was reported for SYTO 11 (Molecular Probes S7574) and 12 (Molecular Probes S7574).

1. Adults are incubated for $4-5$ hours at $23^{\circ} \mathrm{C}$ in a $33 \mu \mathrm{M}$ aqueous solution of SYTO 12 in the dark.

2. Transfer for 1 hour to NGM plates seeded with E. coli OP50.

3. Mount worms on slides

In wild-type animals SYTO 12 has a granular cytoplasmic staining pattern in mid- to late stage oocytes and embryos. SYTO 12 stains both corpses visible by Nomarski optics as well as late stage germ cell corpses that are not visible by Nomarski optics.

Protocol 30: Acridin Orange (AO) staining of dying germ cells (based on Gumienny et al., 1999; Lettre et al., 2004)

$\mathrm{AO}$ is a fluorescent dye that specifically labels apoptotic cells. The dye becomes incorporated by ingestion of 
AO-stained Escherichia coli by C. elegans.

1. Adults are incubated for 1 hours in the dark on seeded NGM plates with $500 \mu$ of M9 buffer containing AO (Molecular probes; $0.02 \mathrm{mg} / \mathrm{ml}$ ).

2. Transfer the stained worms back to regular NGM plates (lacking AO) for one hour.

3. Mount worms on slides and analyze by fluorescence microscopy.

This staining does not work for engulfment defective mutants.

\subsubsection{Dying germ cells visualized using CED-1::GFP}

Plim-7ced-1::gfp expresses a CED-1::GFP fusion protein under the control of the lim-7 promoter (Zhou et al., 2001). The lim-7 promoter drives expression specifically in the sheath cells that form the gonadal tube. These cells are responsible for the engulfment of dying germ cells. The CED-1 protein is a transmembrane protein that is expressed on phagocytotic cells. After contact with an apoptotic cell, the CED-1 protein clusters around the apoptotic cell (Zhou et al., 2001; see Figure 15). This reporter makes it easier to score germ cell death. Even cells at an early apoptotic stage that would hardly be recognizable by DIC are already surrounded by the CED-1::GFP protein. One disadvantage of $\mathrm{P}_{\text {lim- }}$ - ced-1::gfp is the fact that it only weakly labels corpses in genetic backgrounds that cause massive germ cell death, like in ced-9(lf) animals, in which most, if not all, germ cells die.
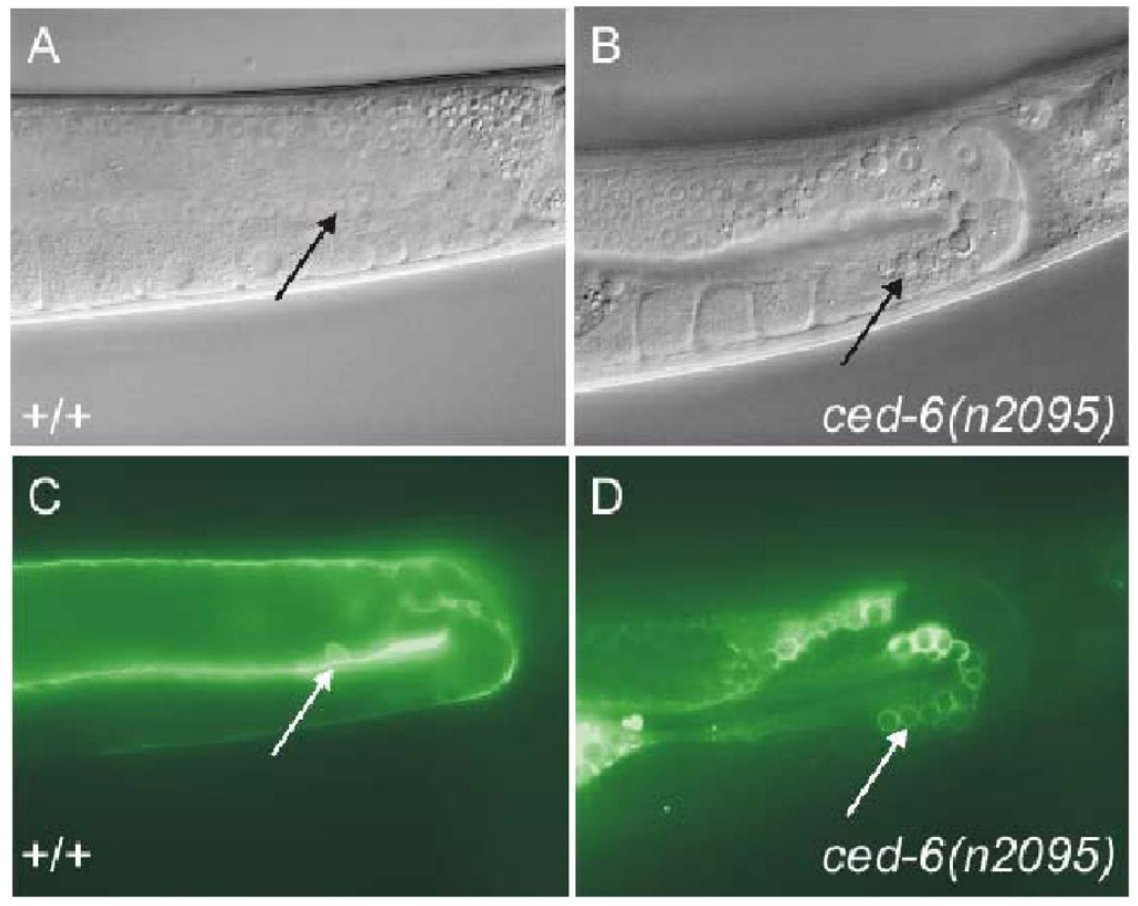

Figure 15. A. DIC image of a wild-type adult hermaphoridite gonad arm showing a single corpse (arrow). B. DIC image of an engulfment defective mutant. Dying cells are indicated by arrow. C and D. Fluorescence images of the Plim-7ced-1::gfp reporter corresponding to A and B, respectively (Claus Schertl and Barbara Conradt).

\subsubsection{Detecting a block in cell death}

A structure that is particularly convenient for analyzing in appropriate cell survival is the anterior pharynx. Nuclei in the anterior pharynx are relatively easy to identify in L3 or L4 larvae by DIC microscopy (Figure 16; Ellis and Horvitz, 1991). During the development of the anterior pharynx, 16 cells undergo programmed cell death in wild-type animals. In egl-l(lf), ced-4(lf), ced-3(lf) and ced-9(gf) animals, in which cell death is blocked, 11-12 extra nuclei can be detected on average in the anterior pharynx. Extra cells in the anterior pharynx appear in distinct 
positions as shown in Figure 16. The number of extra cells is a measure of the extent of the cell death defect.
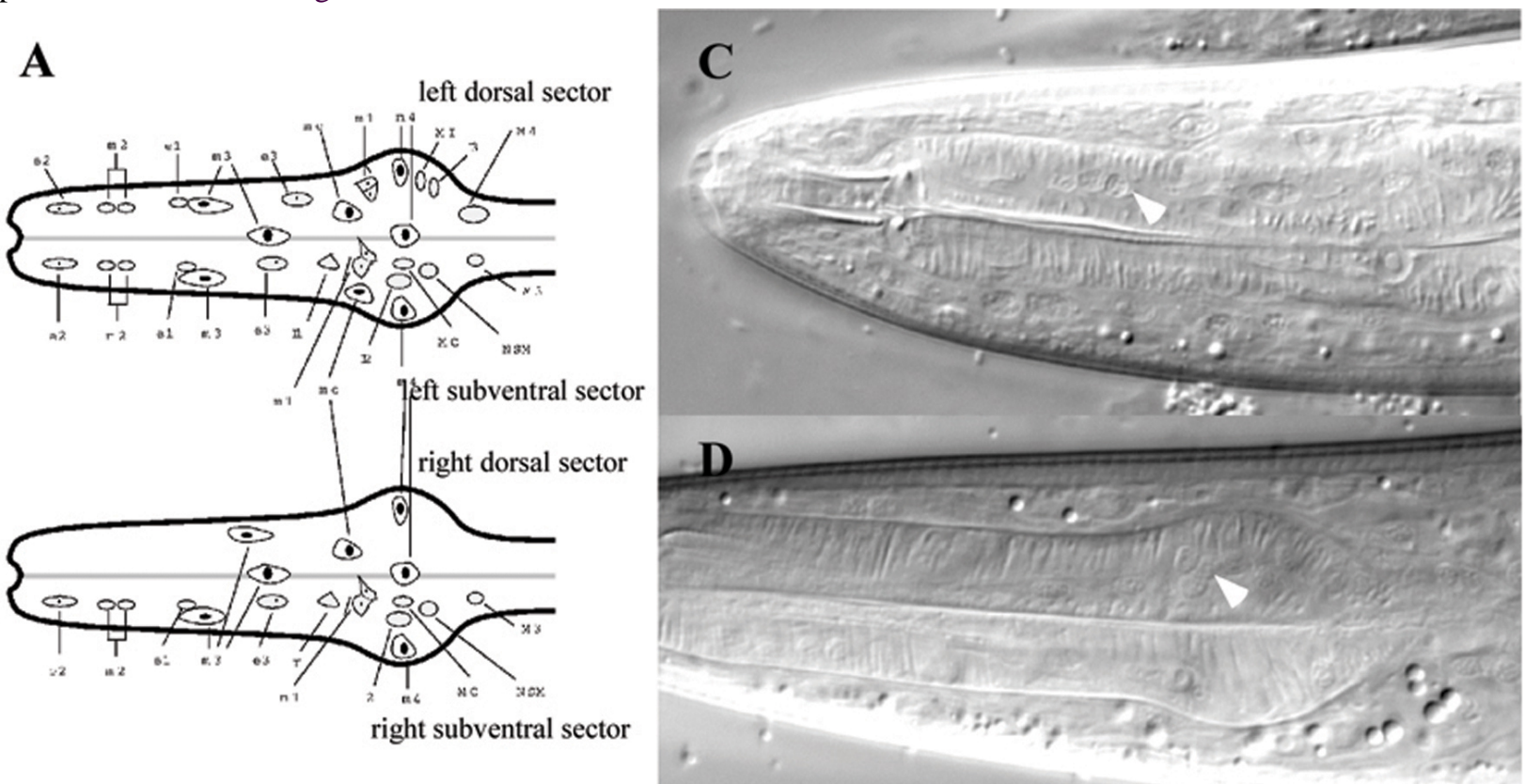

B
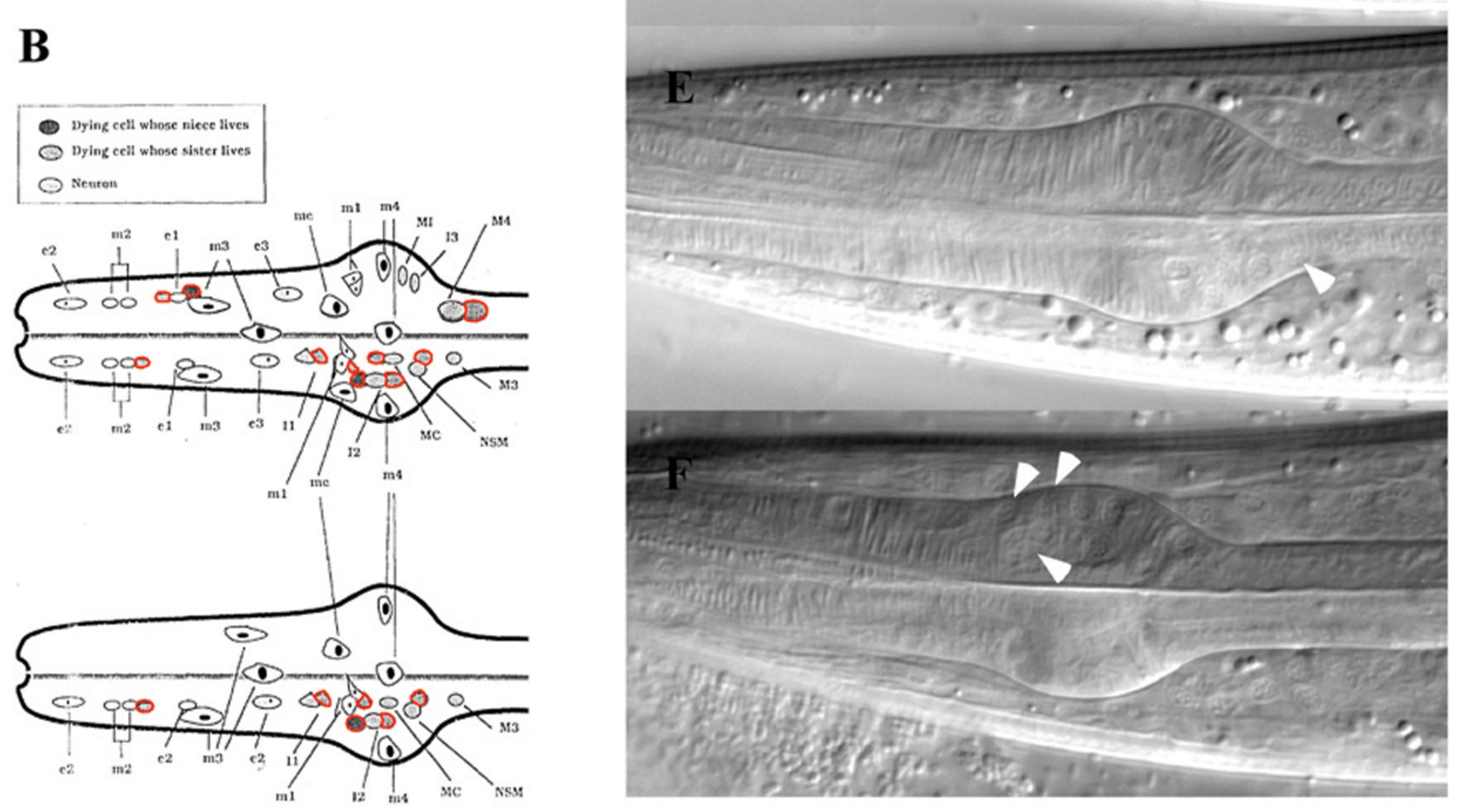

Figure 16. A block in cell death, e.g. caused by a loss-of-function in ced-3, results in the appearance of extra cells in the anterior part of the pharynx. A. schematic representation of the anterior part of a wild-type pharynx. B. Schematic representation of the anterior part of a ced-3(lf) pharynx. In red, extra nuclei are indicated that can be scored as an assay to evaluate a block in cell death. C-E. Nomarski pictures of pharynxes of ced-3(lf) animals. Arrowheads indicate extra nuclei (Julia Hatzold, Barbara Conradt, Ron Ellis).

Inappropriate cell survival can also be scored using gfp reporter transgenes. For example, $\mathrm{P}_{t p h-1} g f p$, is expressed in the NSM neurons and in their sisters if the latter are allowed to survive (Thellmann et al., 2003; Figure 17). 

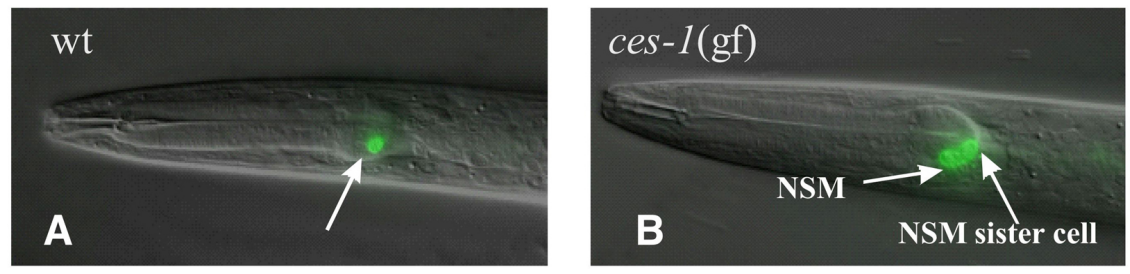

Figure 17. A $t p h-1:$ :gfp reporter is expressed in the NSMs in the anterior part of the pharynx. A. One fluorescent cell can be detected on each side (left and right) of a wild-type animal. B. In a ces-1(gf) animal, the surviving NSM sister cell can be visualized by gfp expression posterior to the NSM (Julia Hatzold and Barbara Conradt).

Most somatic cell deaths occur during embryogenesis and in wild-type animals the cell corpses are engulfed and rapidly degraded. Therefore, cell corpses are rarely found in the head region of freshly hatched L1 larvae (Sulston and Horvitz, 1977; Sulston et al., 1983; Sulston et al., 1983). In ced-1(e1735) animals, however, engulfment is blocked, resulting in the accumulation of cell corpses in L1 larvae (about 23 corpses). If cell death is blocked in this mutant background, for example by a ced-3(lf) mutation, few or no cell corpses are detected (Ellis et al., 1991; (Ellis et al., 1991). Therefore, this assay can also be used to determine if cells that are destined to undergo programmed cell death failed to die.

\subsubsection{Detecting cell corpse engulfment defects}

The analysis of cell corpses in L1 larvae can give information about mutations that result in an engulfment defect. Since 113 out of 131 cell deaths occur during wild-type embryogenesis, no cell corpses are detected in the pharynx of L1 larvae Sulston and Horvitz, 1977; Sulston et al., 1983; Sulston et al., 1983). Therefore, mutants, in which persistent corpses can be detected in freshly hatched L1 larvae, might be defective in engulfment.

\section{Embryonic cell culture}

Studying cellular processes in a living C. elegans offers the advantage of a physiological environment in which these processes occur. However, because of the small size of the animal, and because the cuticle of the animal is a significant permeability barrier, many experiments are difficult or impossible to perform. Thus, for example, rapid modulation of cellular components using drugs is nearly impossible. Furthermore, studies of a particular process may be hampered by other physiological events surrounding the cell being examined, making results sometimes difficult to interpret. Cell culture offers an alternative to in vivo studies, where problems such as those discussed above are obviated (Christensen et al., 2002; Zhang et al., 2002). Interpretation of experiments using cultured cells, of course, suffers from the non-physiological conditions under which the cells are grown. Thus, culture studies and in vivo studies can be complementary, and together can yield significant insight into cell biological questions.

Particular cell types can be labeled with GFP, sorted using fluorescence activated cell sorting (FACS), and studied as a homogeneous population (e.g. to examine expression using gene arrays). Furthermore, RNA interference can be used to inactivate gene expression in cultured cells, allowing for a quasi-genetic dissection of processes in culture. Finally, cells in culture are readily accessible to electrophysiological studies. Methods for culturing embryonic cells were recently developed (Christensen et al., 2002; Zhang et al., 2002) and protocols are presented below (Figure 18). The procedure has been mostly tried with embryonic cells. In general, differentiation of cells in culture seems to proceed through what would be the L1 stage. Markers specific for later stages are not expressed. 


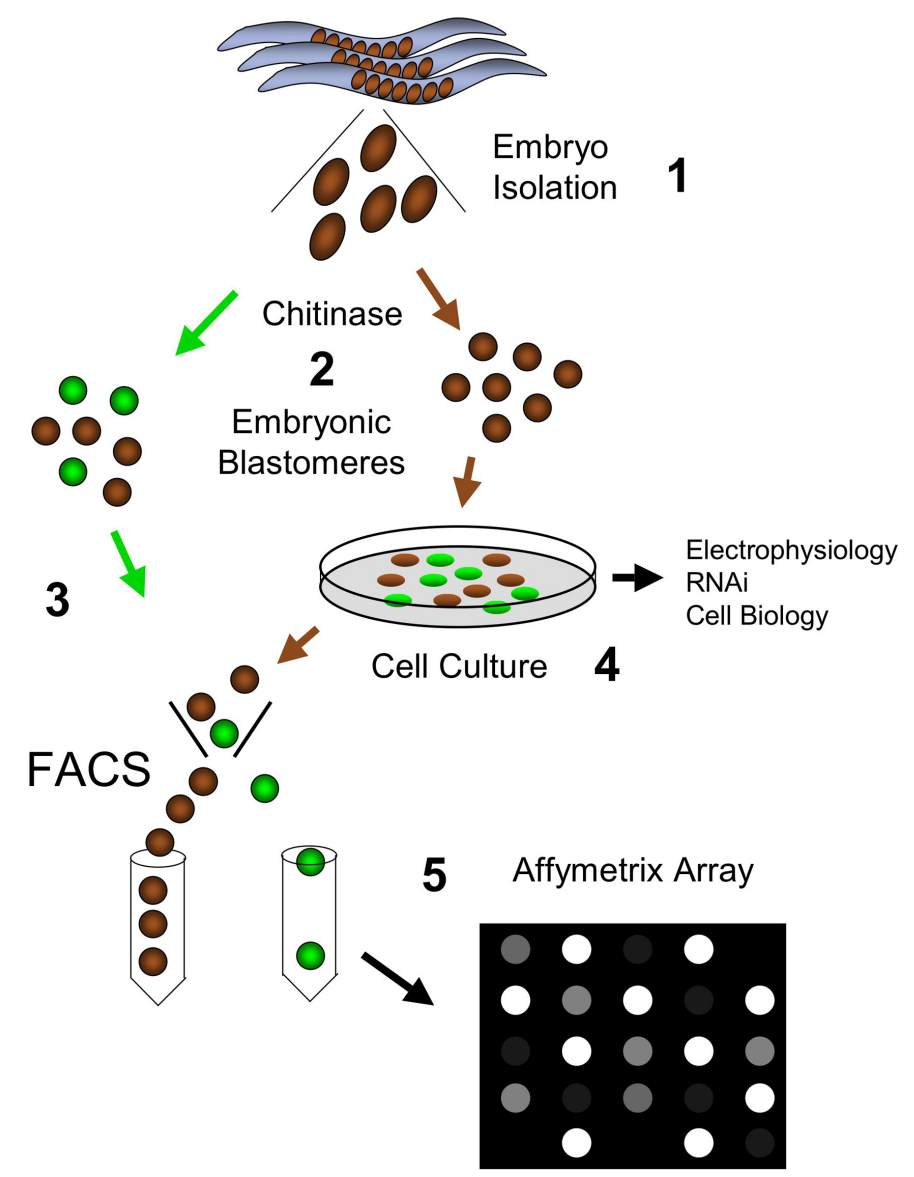

Figure 18. Profiling GFP-labeled embryonic cells. Intact embryos are isolated from gravid adults by hypochlorite treatment. 1. Treatment with chitinase releases embryonic blastomeres. 2. Cells marked with GFP reporters expressed in early embryos (i.e., before morphogenesis at $\sim 400 \mathrm{~min}$ ) are isolated by FACS (e.g. myo-3::GFP body muscle cells) (Green arrows). 3. Alternatively, dissociated blastomeres can be cultured for $24 \mathrm{hr}$ to generate GFP-labeled cells that emerge later in embryonic development (e.g. unc-4::GFP in DA motor neurons) (brown arrows). 4. GFP-marked cells are isolated by FACS and RNA extracted for application to the C. elegans Affymetrix Gene Chip. 5. (Rebecca M. Fox, Susan J. Ruff, and David M. Miller III)

\section{Protocol 31: Primary culture of embryonic cells (Kevin Strange and Rebecca Morrison)}

\section{Isolation of C. elegans eggs}

1. Cultures of synchronized worms are prepared using standard methods

2. Wash synchronized adult worms off agar plates with Milli-Q water into a $15 \mathrm{ml}$ conical tube. Pellet worms by centrifugation at $1200 \mathrm{rpm}(\sim 450 \mathrm{~g})$ for $3 \mathrm{~min}$ in a swinging bucket rotor in a tabletop centrifuge.

3. Wash pelleted worms with Milli-Q water 1-3X until the supernatant is clear of bacteria.

4. After the last wash, lyse the worm pellet with the following fresh mixture of bleach and $\mathrm{NaOH}(1.0 \mathrm{ml}$ bleach, $0.25 \mathrm{ml} 10 \mathrm{~N} \mathrm{NaOH}, 3.75 \mathrm{ml}$ sterile $\mathrm{H}_{2} \mathrm{O}$ ) prepared immediately prior to use.

5. Rock worms gently during the lysis. The progress of the lysis reaction is monitored by viewing the worm suspension with a dissecting microscope and the lysis reaction should be stopped when $\sim 50 \%$ of the worms are lysed. Lysis time is critical. Under no conditions should the lysis reaction exceed $5 \mathrm{~min}$.

6. Stop the lysis reaction by filling the tube with egg buffer $(118 \mathrm{mM} \mathrm{NaCl}, 48 \mathrm{mM} \mathrm{KCl}, 2 \mathrm{mM} \mathrm{CaCl}, 2 \mathrm{mM}$

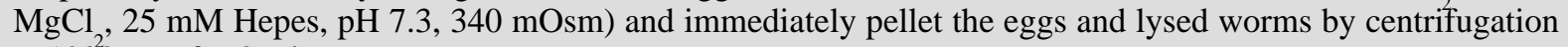
at $1200 \mathrm{rpm}$ for $3 \mathrm{~min}$. 
7. Remove the supernatant using a sterile plastic transfer pipette and wash $3 \mathrm{X}$ with egg buffer. Make sure the pellet is completely re-suspended in the egg buffer during each wash.

8. After the last centrifugation, carefully remove the buffer by sterile plastic transfer pipette.

9. Eggs are separated from debris by centrifugation in a 30\% sucrose solution. Resuspend the pelleted eggs and lysed worms in $5 \mathrm{ml}$ of sterile water and then add $5 \mathrm{ml}$ of a sterile $60 \%$ sucrose stock. Mix this solution well.

10. Centrifuge the suspension at $1200 \mathrm{rpm}(\sim 450 \mathrm{~g})$ for $5-6$ min using a swinging bucket rotor in a tabletop centrifuge.

11. Eggs should float in the $30 \%$ sucrose solution and will collect at the solution meniscus. Some eggs may appear in the region just below the meniscus. Using a sterile plastic transfer pipet (eggs will stick to glass pipets), transfer the eggs at the meniscus into a sterile $15 \mathrm{ml}$ conical tube. Eggs that stick to the tube can be recovered by gently washing down the sides with a small volume of the sucrose solution and then removing them with a plastic transfer pipette.

12. Collect no more than $3-4 \mathrm{ml}$ of the egg/sucrose suspension. Fill the tube with sterile water and re-pellet to remove the sucrose.

\section{Preparation of dissociated embryo cells}

1. After egg isolation, all subsequent steps should be carried out in a laminar flow hood under sterile conditions.

2. Remove embryo eggshells by incubating approximately 50-200 $\mu \mathrm{l}$ of pelleted eggs in $500 \mu \mathrm{l}$ of chitinase (Sigma Chemical Co., St. Louis, MO) solution (1U/ml in sterile egg buffer) in a sterile Eppendorf tube.

3. Mix the egg suspension in the Eppendorf tube by rocking gently at room temperature for 20-80 minutes. Note that each lot of chitinase tends to vary in potency. Consequently, incubation times will have to be assessed for each lot. The progress of eggshell digestion should be monitored by viewing the egg suspension under a microscope.

4. Isolated cells are washed and cultured in L-15 cell culture medium (Life Technologies, Grand Island, NY) containing $10 \%$ heat inactivated fetal bovine serum (HYCLONE, Logan, UT), $50 \mathrm{U} / \mathrm{ml}$ penicillin and $50 \mu \mathrm{g} / \mathrm{ml}$ streptomycin. The osmolality of the culture medium should be adjusted to $340 \mathrm{mOsm}$ with sucrose and filter sterilized. Osmolality can be measured with a vapor pressure or freezing point osmometer. If these instruments are not available, the osmolality of the L-15 cell culture medium is listed on the bottle label. As a first approximation, $1 \mathrm{mM}$ sucrose $\approx 1 \mathrm{mOsm}$. Therefore, osmolality can be increased to $\sim 340 \mathrm{mOsm}$ by adding an equimolar amount of sucrose.

5. When approximately $80 \%$ of the eggshells have been lysed, add $800 \mu \mathrm{l}$ of L-15 cell culture medium to the Eppendorf tube. Pellet the eggs by centrifugation at $\sim 3500 \mathrm{rpm}(\sim 900 \mathrm{~g})$ for $3 \mathrm{~min}$ at $4{ }^{\circ} \mathrm{C}$ in a microcentrifuge.

6. Carefully remove the supernatant and add $800 \mu \mathrm{l}$ of fresh L-15 cell culture medium.

7. Gently dissociate the cells by repeatedly pipetting the cell suspension using a $1 \mathrm{ml}$ Eppendorf pipettor. Monitor the degree of dissociation by periodically placing a drop of the suspension on a microscope slide and viewing at 20X. Continue the dissociation until you have a large number of single cells present. The preparation will also contain some undissociated embryos, clumps of cells and possibly hatched larvae.

8. Pellet the dissociated cell suspension by centrifugation at $\sim 3500 \mathrm{rpm}(\sim 900 \mathrm{~g})$ and $4^{\circ} \mathrm{C}$ for $3 \mathrm{~min}$. Remove the supernatant, which may be somewhat cloudy, and resuspend the pellet in $500 \mu \mathrm{l}$ of L-15 cell culture medium.

9. The cell suspension is filtered to remove hatched larvae, cell clumps and very large cells. Filtration is carried out using a 5.0 micron Durapore filter (Millipore Corporation, Bedford MA) and a $3 \mathrm{ml}$ sterile syringe as follows: 
a. A sterile pipette tip for a 10-100 $\mu$ Eppendorf pipettor is cut off just below the top "nut". The cut tip is inserted onto a sterile syringe. Alternatively, you can use a sterile 18 gauge needle.

b. $\quad 1 \mathrm{ml}$ of L-15 medium is drawn up into the syringe.

c. The cell suspension is then drawn up slowly into the pipette tip and into the bottom of the syringe. Care is taken so that the cell suspension does not mix with the L-15 medium in the syringe.

d. The pipette tip is removed and the 5.0 micron Durapore filter is placed securely onto the syringe.

e. The cell suspension is forced through the filter with "medium" pressure into a sterile Eppendorf tube.

f. To maximize the yield of single cells, the filter is rinsed with L-15 medium as follows. Remove the filter unit from the syringe and attach a new, sterile pipet tip. Draw an additional 1.0-1.5 ml of L-15 medium into the syringe. Remove the tip from the syringe and replace with the filter.

g. Gently force the L-15 medium through the filter into a second sterile Eppendorf tube.

10. Pellet cells by centrifugation at $\sim 3500 \mathrm{rpm}(\sim 900 \mathrm{~g})$ and $4^{\circ} \mathrm{C}$ for $3 \mathrm{~min}$.

11. Remove the supernatants and resuspend the cells in 25-200 $\mu \mathrm{l}$ (the actual volume depends on the size of the cell pellet) of L-15 cell culture medium. After resuspension, pool the two samples.

12. Prepare appropriate dilutions of the cell suspension in L-15 medium and determine cell density using a hemacytometer. Useful counting dilutions range from 1:10 to 1:200. For our experimental purposes, we count only "large" and "medium" cells and ignore any very small cells.

13. Plating density depends on the nature of the experiments that are going to be performed. For patch clamp and optical experiments, we find that a seeding density of $\sim 230,000 \mathrm{cells} / \mathrm{cm}^{2}$ is optimal.

14. Cells must adhere tightly to the growth substrate in order for differentiation to occur. Cells are grown on glass coverslips or plastic dishes with glass coverslip bottoms. The coverslips are coated with peanut lectin (Sigma) to promote cell adhesion.

15. Prepare a peanut lectin solution in sterile water at a concentration of $0.5 \mathrm{mg} / \mathrm{ml}$. For patch clamp studies, cells are grown on $12 \mathrm{~mm}$ diameter acid-washed glass coverslips. Pipette a small volume of the peanut lectin solution onto the coverslip so that it covers about $80 \%$ of the surface. Incubate the coverslips with the lectin solution for 10-20 min and then remove completely. It is important to completely remove the lectin solution. Excess lectin on the coverslips causes cell clumping.

16. Sterilize the coverslips under UV light for several hours. The coverslips can be stored for weeks under sterile conditions. The lectin can also be sterilized by gamma irradiation prior to placing it in solution.

17. Plate the cells onto the coverslips in a minimal volume of L-15 medium. Allow the cells to settle and attach for $2 \mathrm{~h}$ and then add additional L-15 medium.

18. Culture vessels are kept in small sealed Tupperware containers lined with wet paper towels. Prevention of medium evaporation is critical. The Tupperware containers are kept in a sterile, humidified incubator at room temperature and ambient air.

19. In our hands, morphological differentiation of cells is largely complete within $24 \mathrm{~h}$. Cell survival is excellent for 2-3 weeks. However, these are primary cultures and they may dedifferentiate with time. We typically do not use cultures for physiology experiments that are older than 5-8 days. 
Protocol 32: MAPCeL (Micro Array Profiling C. elegans Cells): Embryonic cell culture and FACS for in vitro and gene array studies (Rebecca M. Fox, Susan J. Barlow, Stephen E. Von Stetina and David M. Miller III)

These methods can be used to generate transcriptional profiles of specific cell populations (Fox et al., 2005).

\section{A. Embryo isolation}

1. Synchronize worms by allowing them to exhaust the food supply and starve Remove a small square of agar to transfer dauer larvae to $150 \mathrm{~mm} 8 \mathrm{P}$ plates inoculated with $\mathrm{Na} 22$. Grow for one generation $(\sim 3$ days) until plates are crowded with gravid adults. Average yield is $\sim 10^{7}$ embryonic cells per $150 \mathrm{~mm}$ plate. The procedure outlined below is appropriate for a cell preparation from 5-10 plates of worms.

2. Wash the worms off of each plate with sterile water into a separate $15 \mathrm{ml}$ conical tube.

3. Centrifuge for 2.5 minutes at $2500 \mathrm{rpm}(250 \mathrm{xg})$.

4. Treat with $5 \mathrm{ml}$ of Bleach Solution for 5 minutes.

5. Add $10 \mathrm{ml}$ of egg buffer to stop the reaction and centrifuge for 2.5 minutes at $2500 \mathrm{rpm}$.

6. Wash 3 times in quick succession with egg buffer, or until you can no longer smell the bleach.

7. To separate embryos from carcasses and debris, resuspend pellet in $10 \mathrm{ml}$ of $30 \%$ sucrose solution $(5 \mathrm{ml}$ $60 \%$ sucrose plus $5 \mathrm{ml}$ water) and centrifuge for 2.5 minutes at $2500 \mathrm{rpm}$.

8. Remove embryos (floating on top) with a transfer pipette along with no more than $5 \mathrm{ml}$ of sucrose solution.

9. Dilute to $15 \mathrm{ml}$ with Milli-Q water and centrifuge at 2500 for 2.5 minutes to pellet the embryos.

10. Remove supernatant and proceed to laminar flow hood for additional steps.

\section{B. Dissociating embryos to release early embryonic cells.}

Early embryos (before morphogenesis, $<400 \mathrm{~min}$ ) are largely dispersed to single cell suspensions by these methods whereas older embryos are not. In fact, late stage embryos can be seen crawling around in these preparations prior to their removal in the filtration step (see below).

1. Resuspend embryos in $0.5 \mathrm{ml}$ of sterile chitinase $(0.5 \mathrm{U} / \mathrm{ml})$.

2. Incubate at RT for $\sim 45$ minutes with gentle rocking on nutator. Examine under a dissecting scope after 30 minutes to check for dissociation of embryos. Some batches of chitinase are more potent than others.

3. To stop the reaction, top off the tube $(\sim 1 \mathrm{ml})$ with $\mathrm{L}-15-10$ media (see below) and centrifuge at 12,000 rpm (1300xg) for 2 minutes in microfuge.

4. Aspirate supernatant and resuspend pellet in $1 \mathrm{ml}$ of L-15-10 media with P1000 pipetman.

5. Preload 3cc syringe with $0.5 \mathrm{ml}$ media and draw up cell suspension into barrel. Gently push sample through a $5 \mu \mathrm{m}$ syringe filter into a $1.5 \mathrm{ml}$ microfuge tube. To recover more embryonic cells, reload the syringe with $\sim 1.5 \mathrm{ml}$ media and push it through the filter again into a second microfuge tube. The filtration step is crucially important for removing cell clumps and undissociated embryos.

6. Centrifuge for 3 minutes at $6000 \mathrm{rpm}(350 \mathrm{xg})$ in microfuge at RT.

7. Remove supernatant. For preparations that will be sorted immediately to isolate GFP-labeled cells, resuspend the pellet in egg buffer $\left(\sim 10^{7}\right.$ cells $/ \mathrm{ml}$; See FACS protocol, Section D. below). For cells that will be maintained in culture, resuspend pellet in L15-10 media $\left(\sim 10^{7}\right.$ cells $\left./ \mathrm{ml}\right)$. (See cell culture protocol, 
Section C. below.)

8. Count cells with a hemocytometer.

C. Primary culture of C. elegans embryonic cells for in vitro experiments.

1. For cells that will be characterized in culture (e.g. patch clamping, immunofluorescence staining, etc.), apply the suspension of embryonic blastomeres $\left(\sim 10^{7}\right.$ cells $/ \mathrm{ml}$ in $\mathrm{L} 15-10$ media) to peanut agglutinin-coated glass surfaces (see below).

2. Cells are cultured at $25^{\circ} \mathrm{C}$. Place the culture chamber inside a covered petri dish with a moist paper towel to retard evaporation.

3. Cells are tightly adherent to peanut agglutinin-coated glass. Within $24 \mathrm{hr}$ of plating, body muscle cells assume a bipolar spindle shaped morphology (Figure 19 D,E) and neurons extend elongated processes (Figure 20). Media is changed at 3-4 day intervals and cultures maintained for $\sim 2$ weeks.
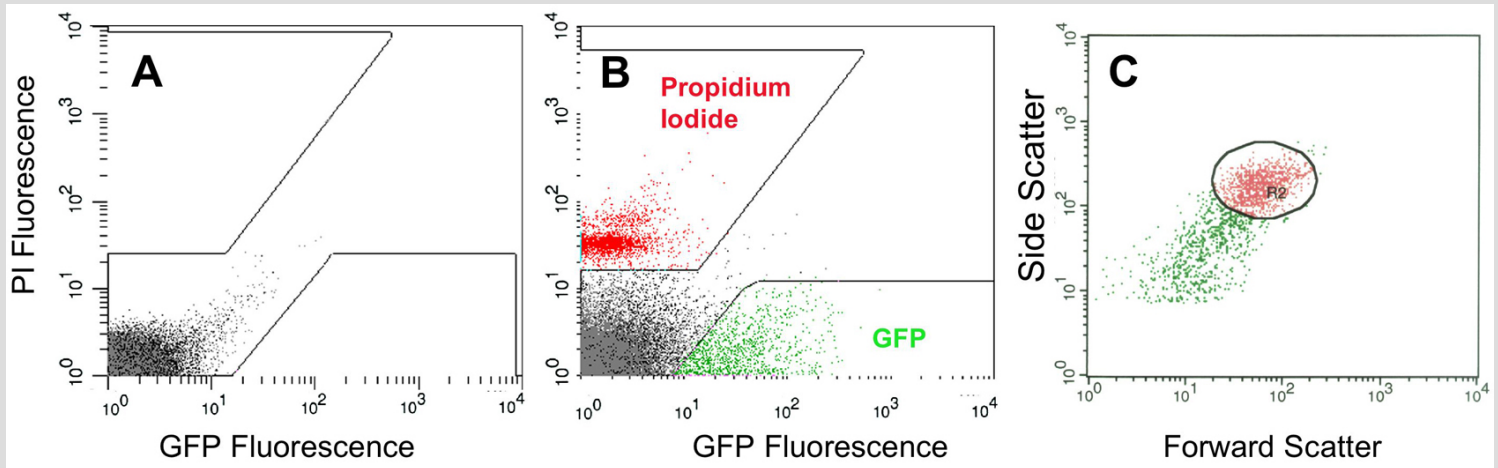

Forward Scatter
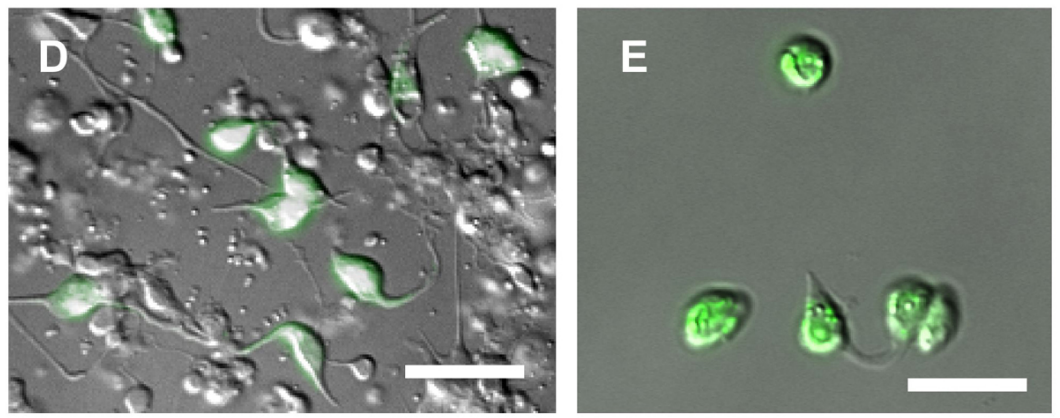

Figure 19. Isolation of embryonic muscle cells by FACS. A. Fluorescence intensity profile of wildtype (non-GFP) cells. Boxed areas exclude autofluorescent cells (arrow). B. myo-3::GFP cells are gated to exclude propidium iodide-stained (non-viable) cells. C. Light scattering gate(R2) for GFP-positive cells (circle). D. Mixed population of embryonic cells from myo-3::GFP embryo before sorting. E. myo-3::GFP cells after FACS enrichment ( 90\%). Scale bars are 5 mm. (Rebecca M. Fox, Susan J. Ruff, and David M. Miller III) 

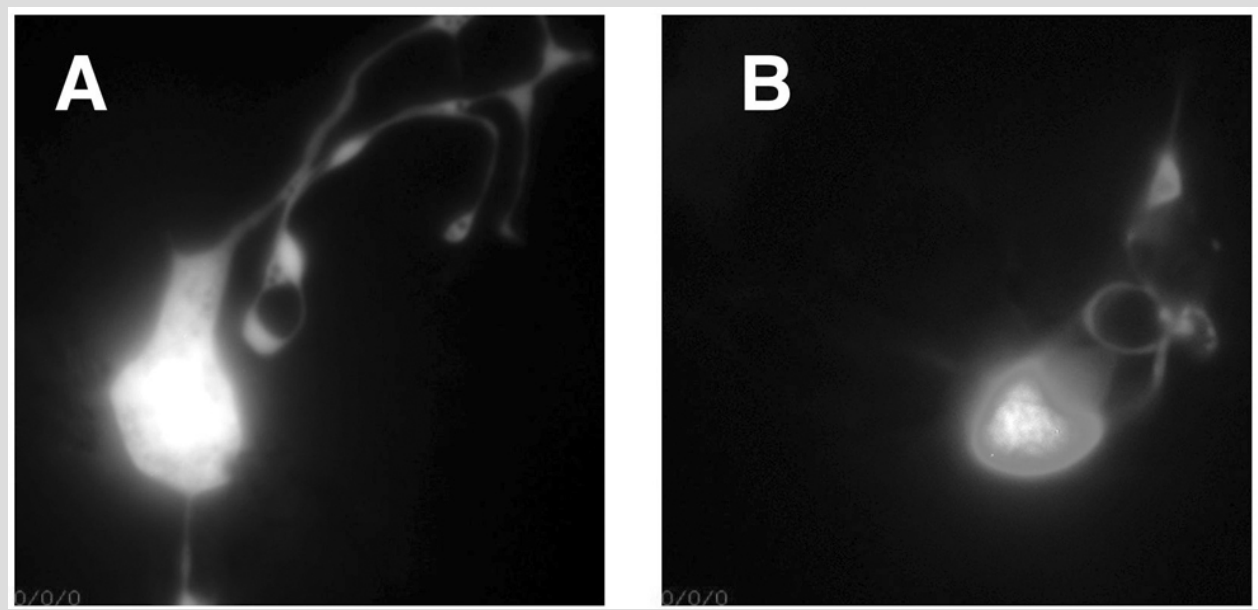

Figure 20. Cultured C. elegans neurons. A. Touch neuron expressing mec-4::GFP. B. ASE neuron expressing $g c y-5::$ GFP. (Erica Keen and Shai Shaham).

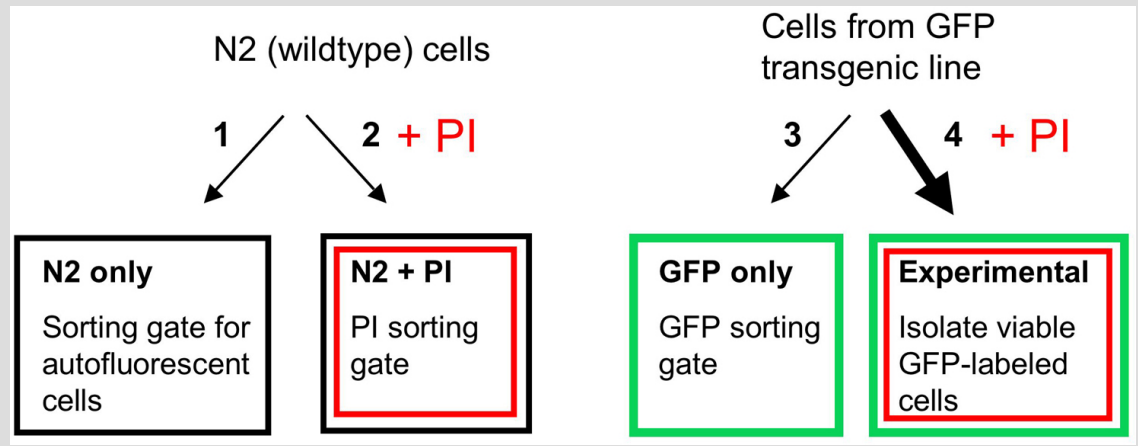

Figure 21. Example of a FACS sorting experiment (Rebecca M. Fox, Susan J. Ruff, and David M. Miller III).

D. Primary culture of $C$. elegans embryonic cells for isolation by FACS.

GFP markers expressed in late stage embryos (> morphogenesis; e.g. unc-4::GFP) are rarely observed in freshly prepared suspensions of blastomeres but do emerge with overnight culture. To recover these cells for isolation by FACS, we plate them on poly-L-lysine from which they can be readily dislodged the next day with gentle mechanical disruption.

1. Plate cells in L15-10 media $\left(\sim 10^{7}\right.$ cells $\left./ \mathrm{ml}\right)$ on poly-L-lysine coated slides and allow to differentiate overnight. Single-well chamber coverglasses work well for this application.

2. Remove media and replace with $1 \mathrm{ml}$ Egg Buffer.

3. Wash cells from slide using P1000 pipetteman. Cells are loosely adherent and are easily dislodged.

4. Pool cell suspensions $(\sim 3 \mathrm{ml})$ and pass through Durapore syringe filter $(5 \mu)$ into $15 \mathrm{ml}$ conical tube.

\section{E. Prepare cells for FACS isolation.}

1. Cells from freshly dissociated embryos or from $24 \mathrm{hr}$ primary cultures are dispersed in egg buffer as described above.

2. You will need four separate preparations of cells for each sorting experiment (see below; Figure 20).

a. $\quad \mathbf{N} 2$ only-non-GFP cells to identify autofluorescent cells 
b. $\quad \mathbf{N} 2+\mathbf{P I}-$ non-GFP cells plus Propidium iodide to set gate for PI-stained cells

c. GFP only-Cells from GFP transgenic embryos to set GFP gate

d. Experimental-Cells from GFP transgenic embryos + PI. Sort to isolate GFP cells

3. $\mathbf{N} 2$ only. Prepare cells $\left(\sim 10^{6}\right)$ from wildtype (N2) embryos.

4. $\mathbf{N} 2+\mathbf{P I}$. Add propidium iodide (PI) to a separate tube of $\mathrm{N} 2$ cells $\left(\sim 10^{6}\right)$.

5. GFP only. Set aside a small aliquot (e.g., $\sim 10^{6}$ cells in $250 \mathrm{ul}$ ) of cells prepared from the GFP transgenic line.

6. Experimental. Transfer the remainder of cells from the GFP transgenic line (2-2.5 ml) to another FACS tube and label, "Experimental." The cell suspension should be clear. If cloudy, add egg buffer to achieve the ideal concentration of $\sim 5-10$ million cells $/ \mathrm{ml}$.

7. Add propidium iodide (PI) to the "Experimental" tube immediately before sorting to a final concentration of $5 \mu \mathrm{g} / \mathrm{ml}$. (e.g. $1 \mathrm{ml}$ of $15 \mu \mathrm{g} / \mathrm{ml}$ PI stock added to $2 \mathrm{ml}$ of cell suspension.) PI stains dead or damaged cells instantly but will also label viable cells after prolonged exposure $(2-3 \mathrm{hr})$.

\section{F. Preparing the FACS machine for sorting $C$. elegans cells.}

1. It is critically important to flush the FACS machine with egg buffer prior to sorting as viability is reduced by exposure to the lower osmolarity of PBS solutions typically used for sorting mammalian cells.

2. Use $2 \mu$ fluorescent beads to calibrate light scattering gates to match the relatively small size of C. elegans embryonic cells.

3. Use the $\mathbf{N 2}$ only sample to generate a fluorescence intensity scatter plot for the PI and GFP channels. Because autofluorescent gut cells are detected in both channels they are largely restricted to the diagonal axis of this scatter plot (Figure 19A).

4. Next, N2 + PI cells are used to establish a sorting gate for dead or damaged cells (Figure 19B).

5. Flow cytometry of the GFP only sample is used to discriminate between autofluorescent and GFP-labeled cells (Figure 19B). We typically use all of these controls prior to every FACS run to re-establish the sorting gate for viable, GFP cells.

\section{G. Isolating GFP cells by FACS}

1. The Experimental sample containing GFP + PI-stained cells is now sorted and viable GFP cells collected (Figure 19B).

2. We have also found it helpful to simultaneously gate GFP cells by light scattering parameters to remove debris and cell clumps (Figure 19C). This gate is empirically defined (see below)

3. Cells are collected in $15 \mathrm{ml}$ conical tubes preloaded with $1 \mathrm{ml}$ of L-15-10 media.

4. For microarray experiments, we collect at least 100,000 GFP cells for each hybridization. For less abundant cell types (e.g. unc-4::GFP) it is necessary to pool cells from multiple runs to reach this figure. In other cases (e.g. myo-3::GFP) more than enough cells are generated in a typical 1-2 hr sorting run.

H. Adjusting FACS sorting gates

Sorting gates are empirically defined for each new GFP line by replating initial batches of sorted cells (on 
peanut lectin) and then counting GFP vs non-fluorescent cells on the following day. This step is especially important for defining light scattering parameters. Using this approach, we have achieved $90 \%$ enrichment of GFP cells for a wide range of neuron and muscle-specific markers (R. Fox, S. Von Stetina, S. Ruff, D. M. Miller, manuscripts in preparation).

All steps are performed in a laminar flow hood.

1. Transfer sorted cells ( $\sim 3 \mathrm{ml}$ volume) into $1.5 \mathrm{ml}$ Eppendorf tubes.

2. Centrifuge at $6000 \mathrm{rpm}(350 \mathrm{xg})$ for $5 \mathrm{~min}$ in a microfuge.

3. Remove most of the supernatant. It is important to be VERY careful because you cannot see a pellet. We generally leave $\sim 100$ ul of solution in the tube. This can then be transferred to a peanut lectin-coated slide for visualization. MatTek round dishes work well.

4. Determine the fraction of GFP-positive cells $24 \mathrm{hr}$ after replating by direct inspection in inverted microscope.

\section{Isolating RNA for Microarray experiments.}

1. Transfer sorted cells ( $\sim 3 \mathrm{ml}$ volume) into $1.5 \mathrm{ml}$ Eppendorf tubes.

2. Centrifuge at $6000 \mathrm{rpm}$ for $5 \mathrm{~min}$ in a microfuge.

3. Isolate RNA with Stratagene micro RNA isolation kit (200344) - use volumes suggested for $10^{6}$ cells.

4. Yields are typically $\sim 1 \mathrm{pg}$ total RNA/cell.

5. Lyophilize pellets and store at $-80^{\circ} \mathrm{C}$.

\section{Equipment}

Tissue Culture Hood

Clinical Centrifuge

Microfuge

Inverted compound microscope with fluorescence and DIC optics.

Must have at least 40x and preferably 63x, 100x objectives. (e.g. Zeiss Axiovert)

Osmometer (Wescor)

\section{FACS Machine:}

Sorting experiments were performed in a FACStar Plus flow cytometer (Becton Dickinson, San Jose, CA) equipped with a $488 \mathrm{~nm}$ argon laser and FITC filter set. Emission filters were $530 \pm 30 \mathrm{~nm}$ for GFP fluorescence and $585 \pm 22 \mathrm{~nm}$ for PI fluorescence. Sorting rates were $4000-5000$ cells per second through a $70 \mu \mathrm{m}$ nozzle.

\section{REAGENTS AND MATERIALS}

Peanut lectin coated slides - We routinely use $\gamma$ irradiation (overnight) to sterilize peanut agglutinin powder. Dissolve in sterile $\mathrm{dH} 0$ at $0.5 \mathrm{mg} / \mathrm{ml}$ and use to coat entire surface of slide (e.g., for 1-well chamber coverglass add $2 \mathrm{ml}$ ). Incubate for $\sim 20 \mathrm{~min}$ in a tissue culture hood. It is important to remove excess liquid prior to adding cells to avoid clumping. As an alternative to $\gamma$ irradiation, slides may also be sterilized by exposure to UV light for 30-60 min after application of the peanut agglutinin solution.

Poly-L-lysine -poly-L-lysine solution $\left(0.01 \%\right.$ in sterile $\left.\mathrm{H}_{2} 0\right)$ is sterilized by filtration $(0.2$ micron $)$. Apply to coat the entire surface of slide. Incubate for $\sim 30$ minutes with chamber covered. Wash slide thoroughly with sterile water; residual poly-L-lysine is toxic to cells. Allow to dry uncovered under tissue culture hood. 


\section{Preparation 8P plates:}

\begin{tabular}{|l|l|}
\hline For $1 \mathrm{~L}$ & \\
\hline $\mathrm{NaCl}$ & $3 \mathrm{~g}$ \\
\hline Agar & $25 \mathrm{~g}$ \\
\hline Bactopeptone & $20 \mathrm{~g}$ \\
\hline
\end{tabular}

After Autoclaving add:

\begin{tabular}{|l|l|}
\hline Cholesterol & $1 \mathrm{ml}$ \\
\hline $1 \mathrm{M} \mathrm{CaCl}_{2}$ & $1 \mathrm{ml}$ \\
\hline $1 \mathrm{M} \mathrm{MgSO}_{4}$ & $1 \mathrm{ml}$ \\
\hline $\mathrm{KPO}_{4} \mathrm{pH}^{2} .0$ Buffer & $25 \mathrm{ml}$ \\
\hline
\end{tabular}

Add $60 \mathrm{ml}$ agar/ $150 \mathrm{~mm}$ plastic petri plate

Seed with Na22 bacteria

\section{Bleach Solution}

For $10 \mathrm{ml}$ :

$7.5 \mathrm{ml}$ Milli-Q water

2 ml Clorox

$0.5 \mathrm{ml} 10 \mathrm{~N} \mathrm{NaOH}$

\begin{tabular}{|l|c|c|}
\hline Egg Buffer & $500 \mathrm{ml}$ & $1000 \mathrm{ml}$ \\
\hline $\mathrm{NaCl}(118 \mathrm{mM})$ & $3.448 \mathrm{~g}$ & $6.896 \mathrm{~g}$ \\
\hline $\mathrm{KCl}(48 \mathrm{mM})$ & $1.789 \mathrm{~g}$ & $3.578 \mathrm{~g}$ \\
\hline $\mathrm{CaCl}_{2} \cdot 2 \mathrm{H}_{2} \mathrm{O}(2 \mathrm{mM})$ & $0.147 \mathrm{~g}$ & $0.294 \mathrm{~g}$ \\
\hline $\mathrm{MgCl}_{2} \cdot 6 \mathrm{H}_{2} \mathrm{O}(2 \mathrm{mM})$ & $0.203 \mathrm{~g}$ & $0.406 \mathrm{~g}$ \\
\hline $\mathrm{HEPES}(25 \mathrm{mM})$ & $2.979 \mathrm{~g}$ & $5.958 \mathrm{~g}$ \\
\hline
\end{tabular}

It is important that these weights are exact because of the osmotic sensitivity of C. elegans embryonic cells. Adjust to $\mathrm{pH} 7.30$ with $1 \mathrm{~N} \mathrm{NaOH}$ (no more than $10 \mathrm{ml}$ ).

The optimum osmolarity is $335-345$. Check in osmometer.

Sterilize with $0.2 \mu \mathrm{m}$ bottle top filters.

\section{Adjust osmolarity of L-15 media}

Sucrose is added to increase the osmolarity of L-15 media to $340 \mathrm{mOsm}$ as below:

Read L-15 media in osmometer. ( $\sim 315 \mathrm{mOsm})$

Calculate final concentration of sucrose needed for adjusting L-15 to $340 \mathrm{mOsm}$ :

$340 \mathrm{mOsm}-315 \mathrm{mOsm}=25 \mathrm{mM}$ Sucrose 
Calculate sucrose (solid) for $500 \mathrm{ml} \mathrm{L-15}$ media:

(MW Sucrose $=342.3 \mathrm{~g}$ )

$0.5 \mathrm{~L} \times 0.025 \mathrm{~mole} / \mathrm{l} \times 342.3 \mathrm{~g} / \mathrm{mole}=4.28 \mathrm{~g}$ sucrose

Confirm final osmolarity of 340-345 mOsm in osmometer.

\section{L-15-10 Media}

$500 \mathrm{ml} \mathrm{L}-15$ media adjusted to $340-345 \mathrm{mOsm}$ (see above)

$50 \mathrm{ml}$ Heat inactivated FBS $(10 \%)$

(Heat inactivate $\mathrm{FBS}$ at at $56^{\circ} \mathrm{C}$ for $30 \mathrm{~min}$ )

$2.5 \mathrm{ml}$ of Pen/Strep (1:200)

Sterilize with Nalgene $0.2 \mu \mathrm{m}$ filter.

Store at $4 \mathrm{C}$.

\section{Propidium iodide (3x)}

$15 \mathrm{ug} / \mathrm{ml}$ in egg buffer. Good for 1 week at RT.

Catalog numbers:

L-15 - Gibco 21083-027

Chitinase - Sigma C- 1525

Peanut Agglutinin - Sigma L-0881

Poly-L-Lysine - Sigma P4832

Fetal Bovine Serum -VWR 16777-014; HyClone SH30071.03

Pen/Strep- Gibco 15140-122

Propidium Iodide-Sigma P-4170

Durapore filter (5 $\mu \mathrm{m})$ - Millipore, SLSV R25 LS

\section{Plates etc:}

MatTek $35 \mathrm{~mm}$ Glass Bottom microwell dishes - uncoated

P35G-0-14-C

LabTek Chambered Coverglass

4 well - 155383

2 well - 155380

1 well - 155361

LabTekII Chamber slide with Cover (4 well) - 154526

\section{Tubes}

$1.5 \mathrm{ml}$ microfuge tubes

5ml Polystyrene Round-Bottom Tube (FACS tube) Falcon 352054 (Fisher)

\section{Protocol 33: Embryonic cell culture (Yun Zhang and Marty Chalfie)}

\section{Growing synchronized gravid adults}

1. Grow worms on fifty $6 \mathrm{~cm}$ diameter NGM plates at $20^{\circ} \mathrm{C}$ for 3 to 4 days until the bacterial lawns are consumed.

2. Transfer agar from the plates to twenty $15 \mathrm{~cm}$ NGM agarose plates (these differ from the agar plates in having 
$10 \mathrm{~g} / \mathrm{L}$ agarose instead of agar and $12 \mathrm{~g} / \mathrm{L}$ peptone) and grow for 2 days until the plates contain a large number of eggs.

3. Wash larvae and adults from the plates with M9 buffer, leaving the essentially synchronized eggs. Grow animals with concentrated OP50 E. coli for 3 to 4 days to get gravid adults. $1 \mathrm{ml} /$ plate of concentrated OP50 is used for the first two days and $2-3 \mathrm{ml} /$ plate is used for each succeeding day.

4. Harvest animals when the plates have large numbers of gravid adults, but still have some bacteria (starved worms and dauers are more resistant to the hypochlorite solution in the next step, and will, thus, result in a lower yield of embryos or contamination of the embryo preparation). Worms are collected and washed $3 \mathrm{X}$ (or until most bacteria are removed) with M9 buffer; pellet worms in conventional tabletop centrifuge at 2,000 rpm for 2 minutes.

\section{Collection and staging of embryos}

These and all subsequent steps should be done under sterile conditions.

1. Collect embryos by dissolving adults in 2-4 volumes of freshly-prepared hypochlorite solution. Gently shake the solution and at the same time closely observe one drop of solution under a dissection microscope to determine when all the worm bodies have dissolved and the embryos are exposed (usually 5 min). Extended exposure of embryos to the hypochlorite solution damages the embryos and decreases cell yield.

2. Wash the isolated embryos $3 \mathrm{X}$ with $\mathrm{M} 9$ buffer and pellet in a conventional tabletop centrifuge at 2,000 rpm for $1 \mathrm{~min}$.

3. Resuspend the embryos in M9 buffer and maintain at $21^{\circ} \mathrm{C}$ for $2-4 \mathrm{hrs}$ to allow embryos to develop to the 300-400 cell stage. Monitor the age of the embryos by observing aliquots using differential interference contrast (DIC). (The 300-400 cell stage is the optimum time for culturing the embryonic touch receptor neurons; growth of other cells may require embryos at a different stage.)

\section{Isolation of cells from the embryos}

1. Divide the staged embryos between two $50 \mathrm{ml}$ conical tubes, wash embryos $1 \mathrm{X}$ with $25 \mathrm{ml}$ egg buffer, and remove as much of the buffer as possible.

2. Resuspend the embryos in 2 volumes (usually $20 \mathrm{ml}$ per tube) of chitinase/chymotrypsin solution and gently shake at room temperature. Monitor the embryos by DIC to determine that the eggshells have been digested (usually $5 \mathrm{~min}$ - extended treatment damages the cells).

3. Wash the embryos with egg buffer and pellet them at 2,000 rpm for $1 \mathrm{~min}$.

4. Add two volumes of a $0.25 \%$ trypsin, $1 \mathrm{mM}$ EDTA (Gibco) solution to the pelleted embryos and incubate at room temperature for $5 \mathrm{~min}$ with gentle shaking. Further dissociate cells by pipeting the resuspended embryos gently up and down $10 \mathrm{X}$ with a Pasteur pipet (drawn out to have a $0.3-0.5 \mathrm{~mm}$ diameter opening that has been fire polished). The suspension, viewed with DIC, should contain mostly separated cells, very few cell clumps, and some debris from lysed cells. If the dissociation is incomplete, repeat the 5 min trypsin/EDTA incubation and 10X pipeting.

5. Stop the trypsin treatment by adding ten volumes of L-15CM medium to the cell suspension and pellet the separated cells at 2,000 rpm for 5 minutes.

6. Wash cells $2 \mathrm{X}$ with L-15CM medium and resuspend cells in L-15SFM medium.

7. Place the cell suspension on ice for 10 min to allow big cell clumps to settle.

8. Collect the supernatant and pellet cells at $1,000 \mathrm{rpm}$ for $10 \mathrm{~min}$.

9. Wash the cells once with L-15SFM and resuspend in 2-3 volumes of L-15SFM. 
10. Plate cells on TESPA treated microscopic slides. Place each slide in a $10 \mathrm{~cm}$ diameter culture dish that is placed in water in a $15 \mathrm{~cm}$ diameter culture dish to prevent the slides from dehydrating. Incubate the cells at $21^{\circ} \mathrm{C}$ for two hours to allow them to attach to the slides.

11. Gently add large amounts of L-15CM to cover the cells and let the cells grow in the dark at $21^{\circ} \mathrm{C}$ for $8-12 \mathrm{hr}$. The twenty $15 \mathrm{~cm}$ plates of animals generate several billion cells, which we usually put on 30 microscopic slides.

\section{$\underline{\text { Solutions }}$}

Concentrated OP50: Culture OP50 overnight at $37^{\circ} \mathrm{C}$ in $12 \mathrm{~L}$ of Superbroth, pellet, and resuspend in $60 \mathrm{ml}$ of M9 buffer (final volume approximately $120 \mathrm{ml}$ ). Store at $4^{\circ} \mathrm{C}$ until needed.

Hypochlorite solution: $1 \mathrm{ml}$ sodium hypochlorite (Sigma), $2.5 \mathrm{ml} 1 \mathrm{M} \mathrm{NaOH}, 1.5 \mathrm{ml} \mathrm{dH}_{2} \mathrm{O}$.

Egg buffer: $11.8 \mathrm{ml} 1 \mathrm{M} \mathrm{NaCl}, 4.8 \mathrm{ml} 1 \mathrm{M} \mathrm{KCl}, 0.34 \mathrm{ml} 1 \mathrm{M} \mathrm{CaCl}_{2}, 0.34 \mathrm{ml} 1 \mathrm{M} \mathrm{MgCl}_{2}, 2.0 \mathrm{ml} 0.25 \mathrm{M}$ HEPES (pH 7.4), $82.5 \mathrm{ml} \mathrm{dH}_{2} \mathrm{O}$. Filter-sterilize and store at $4^{\circ} \mathrm{C}$.

Chitinase/chymotrypsin: $5 \mathrm{mg}$ chitinase (Sigma C-6137), $5 \mathrm{mg}$ alpha- chymotrypsin (ICN 152272), $1 \mathrm{ml}$ egg buffer, $10 \mu \mathrm{l}$ penicillin-streptomycin [Cat. No. 15140-148, 10,000 units of Penicillin (base) and 10,000 $\mu \mathrm{g}$ of Streptomycin base $/ \mathrm{ml}$, Gibco]. Freeze in $10 \mathrm{ml}$ aliquots at $-20^{\circ} \mathrm{C}$.

L-15CM: $24 \mathrm{ml} \mathrm{L-15} \mathrm{(Gibco),} 6 \mathrm{ml}$ inulin [ICN 102055; $7.5 \mathrm{mg} / \mathrm{ml}$ egg salts, autoclaved and stored at $4^{\circ} \mathrm{C}$ ], $0.4 \mathrm{ml}$ base mix (D8), $200 \mathrm{mg}$ PVP (polyvinylpyrrolidone, Sigma), $0.4 \mathrm{ml}$ penicillin-streptomycin (Gibco). Filter-sterilize, add $8 \mathrm{ml}$ fetal bovine serum (Heat-inactivated, Sigma), and store at $4{ }^{\circ} \mathrm{C}$ until needed on the same day.

L-15SFM: $24 \mathrm{ml} \mathrm{L-15,} 6 \mathrm{ml}$ inulin, $0.4 \mathrm{ml}$ base mix, $10 \mathrm{ml}$ egg buffer, $0.4 \mathrm{ml}$ penicillin-streptomycin, $100 \mathrm{mg}$ PVP. Filter-sterilize and store at $4^{\circ} \mathrm{C}$.

TESPA-coated slides: Soak microscopic slides in $70 \%$ ethanol and $1 \% \mathrm{HCl}$ for 1 to 2 hours. Rinse $3 \mathrm{X}$ with $\mathrm{ddH}_{2} \mathrm{O}$. Air-dry and sterilize slides under a culture hood UV lamp for $1 \mathrm{hr}$ (all subsequent steps should be performed under sterile conditions). Soak slide in 4\% TESPA (3-aminopropyltriethoxysilane, Sigma)/acetone solution for 5 min. Wash slides in acetone twice. Air dry. Soak slides in 4\% paraformaldhyde/PBS solution for 30 min at room temperature. Wash slides in sterile water for four times. Air dry and store at room temperature. Treated slides have to be used within 3 days.

Egg salts: $11.8 \mathrm{ml} 1 \mathrm{M} \mathrm{NaCl}, 4.8 \mathrm{ml} 1 \mathrm{M} \mathrm{KCl}, 83.6 \mathrm{ml} \mathrm{H}_{2} \mathrm{O}$.

Base mix: $100 \mathrm{ml} \mathrm{H}$ O, $100 \mathrm{mg}$ adenine, $10 \mathrm{mg}$ ATP, $3 \mathrm{mg}$ guanine, $3 \mathrm{mg}$ hypoxanthine, $3 \mathrm{mg}$ thymine, $3 \mathrm{mg}$ xanthine, $3 \mathrm{mg}$ uridine, $5 \mathrm{mg}$ ribose, $5 \mathrm{mg}$ deoxyribose; autoclave and store at $4^{\circ} \mathrm{C}$.

Protocol 34: Linear Amplification of mRNA from cultured cells (Yun Zhang and Marty Chalfie based on Zhang et al., 2002)

\section{Isolation of mRNA}

1. Pellet sorted cells in an Eppendorf centrifuge at 12,000 rpm for 8 min and lyse them using the RTL buffer from the RNeasy Mini kit (Ambion).

2. Vortex the lysate for $1 \mathrm{~min}$ and pass through a QIAshredder column (Ambion). The lysate can be stored at $-80^{\circ} \mathrm{C}$ overnight. RNA quality decreases, however, with the extended storage. Isolate total RNA with the RNeasy Mini kit with the DNase I set (Ambion).

3. Purify mRNA with the mRNA oligotex minikit (Ambion) according to manufacturer's instructions. 
First round amplification

1. (TTGTAATACGACTCACTATAGGGAGG24T; HPLC purified) to $13.75 \mu \mathrm{l}(\sim 100 \mathrm{pg})$ of isolated mRNA. This shorter oligo helps prevent template-independent amplification. Heat to $65^{\circ} \mathrm{C}$ for $5 \mathrm{~min}$ and chill on ice for 3 minutes before adding:

\begin{tabular}{|l|l|}
\hline $2 \mu \mathrm{l}$ & $10 \times$ SensiScript RT reaction buffer (Ambion) \\
\hline $2 \mu \mathrm{l}$ & $10 \times$ d-NTP mix (with SensiScript RT) \\
\hline $0.25 \mu \mathrm{l}$ & RNase Inhibitor (Stratagene) \\
\hline $1 \mu \mathrm{l}$ & SensiScript RT (Ambion) \\
\hline
\end{tabular}

Mix thoroughly and incubate at $37^{\circ} \mathrm{C}$ for 1 hour. Stop the reaction by putting it on ice.

2. Formation of double-stranded cDNA. Mix the following thoroughly and incubate at $16^{\circ} \mathrm{C}$ for 2 hour.

\begin{tabular}{|c|c|}
\hline $20 \mu \mathrm{l}$ & Reverse transcription reaction mix \\
\hline $16 \mu \mathrm{l}$ & $5 \times$ second strand buffer $(\mathrm{D} 1)$ \\
\hline $3.2 \mu \mathrm{l}$ & $10 \times$ d-NTP mix $(5 \mathrm{mM}$ each $)$ \\
\hline $8 \mu \mathrm{l}$ & 100 mM DTT (Gibco) \\
\hline $2.4 \mu \mathrm{l}$ & DNA polymerase I (NEB, 10 unit/ $\mu \mathrm{l}$ ) \\
\hline $0.5 \mu \mathrm{l}$ & DNA ligase (NEB, 10 unit/ $\mu \mathrm{l})$ \\
\hline $0.3 \mu \mathrm{l}$ & RNase H (Gibco, 3 unit/ $\mu$ l) \\
\hline $29.6 \mu \mathrm{l}$ & RNase- and DNase-free $\mathrm{H}_{2} \mathrm{O}$ (Ambion) \\
\hline
\end{tabular}

Add $2 \mu \mathrm{T} \mathrm{T} 4$ DNA polymerase (NEB, 3 unit/ $\mu \mathrm{l}$ ) and continue the incubation at $16^{\circ} \mathrm{C}$ for 30 minutes. Add $80 \mu \mathrm{l} \mathrm{phenol/chloroform} \mathrm{(25:24)} \mathrm{mix,} \mathrm{vortex,} \mathrm{and} \mathrm{spin} \mathrm{at} \mathrm{14,000} \mathrm{rpm} \mathrm{in} \mathrm{an} \mathrm{Eppendorf} \mathrm{centrifuge} \mathrm{at} \mathrm{room}$ temperature for 3 minutes. Transfer the supernatant to a new tube. Repeat extraction once. Recover the double-stranded cDNA from reaction solution, using $10 \mathrm{ng}$ DstNI digested pBR322 as carrier, by GENECLEAN II (BIO 101) according to manufacturer's instruction. Elute cDNA into $29 \mu \mathrm{l}$ Tris (pH 8.0).

3. in vitro transcription. In the following we use the in vitro Transcription Kit for T7 RNA Polymerase from Ambion, except that we substitute the Epicenter T7 RNA polymerase (2,500 unit/ $\mu$ l). This polymerase is at a higher concentration and gives better amplification. Mix the following thoroughly

\begin{tabular}{|l|c|}
\hline $29 \mu \mathrm{l}$ & double stranded cDNA \\
\hline $8 \mu \mathrm{l}$ & $10 \times$ reaction buffer \\
\hline $32 \mu \mathrm{l}$ & NTP mix $(8 \mu \mathrm{l}$ for each $)$ \\
\hline $8 \mu \mathrm{l}$ & Enzyme mix \\
\hline $3 \mu \mathrm{l}$ & T7 RNA polymerase \\
\hline
\end{tabular}

$8 \mu$ of the reaction can be mixed in another tube with $0.8 \mu \mathrm{l} \alpha-\mathrm{P}^{32}$-CTP. Incubate both tubes at $37^{\circ} \mathrm{C}$ for 18 hours. Purify transcripts from cold reaction using the RNeasy Minikit. Precipitate the hot reaction with 5\% 
trichloroacetic acid and $20 \mathrm{mM}$ sodium pyrophosphate to determine the amount of transcription ${ }^{2}$.

\section{$\underline{\text { Second round amplification }}$}

1. Reverse transcription. Mix $10 \mu \mathrm{l}$ of the first round amplified RNA with random hexamer (Gibco, $18 \mathrm{ng}$ primer/ $\mu \mathrm{g}$ RNA), adjust the volume to $11.7 \mu \mathrm{l}$, and heat to $70^{\circ} \mathrm{C}$ for $10 \mathrm{~min}$. Chill on ice for $2 \mathrm{~min}$ and add

\begin{tabular}{|l|c|}
\hline $4 \mu \mathrm{l}$ & $5 \mathrm{X}$ reaction buffer (Gibco) \\
\hline $0.8 \mu \mathrm{l}$ & dNTP mix (25 mM for each) \\
\hline $2 \mu \mathrm{l}$ & $100 \mathrm{mM}$ DTT (Gibco) \\
\hline $0.5 \mu \mathrm{l}$ & Superase In (Ambion) \\
\hline
\end{tabular}

Incubate at $45^{\circ} \mathrm{C}$ for $10 \mathrm{~min}$ and add $1 \mu \mathrm{l}$ SuperScript RT (Gibco). Incubate at $37^{\circ} \mathrm{C}$ for $1 \mathrm{hr}$. Recover the nucleic acid from solution by GENECLEAN II and elute with $12 \mu \mathrm{l}$ Tris (pH 8.0).

2. Formation of double-stranded cDNA. Add $1 \mu \mathrm{l}$ of $1 \mu \mathrm{g} / \mu \mathrm{l} \mathrm{T7}$-promoter linked oligo dT to $12 \mu \mathrm{l}$ of the single stranded cDNA and heat for $3 \mathrm{~min}$ at $95-100{ }^{\circ} \mathrm{C}$ to degrade RNA. Chill on ice and then add

\begin{tabular}{|c|c|}
\hline $2 \mu \mathrm{l}$ & $10 \times$ KFI buffer $(\mathrm{D} 2)$ \\
\hline $2 \mu \mathrm{l}$ & d-NTP mix (2.5 mM each) \\
\hline $1 \mu \mathrm{l}$ & 100 mM DTT (Gibco) \\
\hline $1 \mu \mathrm{l}$ & T4 DNA polymerase (NEB, 10 unit/ $\mu \mathrm{l})$ \\
\hline $1 \mu \mathrm{l}$ & 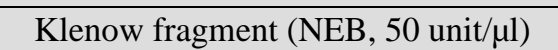 \\
\hline
\end{tabular}

Incubate at $14^{\circ} \mathrm{C}$ for 12 hours and recover double-stranded cDNA by GENECLEAN II.

3. in vitro transcription reaction. Follow the procedure for the first round amplification except carry out the reaction for $10 \mathrm{hr}$. Recover the amplified RNA using the RNeasy Minikit.

\section{$\underline{\text { Solutions }}$}

$\underline{5 X}$ second stranded buffer: $500 \mathrm{mM} \mathrm{KCl}, 50 \mathrm{mM}\left(\mathrm{NH}_{4}\right)_{2} \mathrm{SO}_{4}, 25 \mathrm{mM} \mathrm{MgCl}, 0.75 \mathrm{mM} \mathrm{NAD}^{+}$(nicotinamide adenine dinucleotide), $100 \mathrm{mM}$ Tris. $\mathrm{Cl}(\mathrm{pH} 7.5)$, and $0.25 \mathrm{mg} / \mathrm{ml} \mathrm{BSA}$.

10X KFI buffer: $200 \mathrm{mM}$ Tris (pH 7.5), $100 \mathrm{mM} \mathrm{MgCl}, 50 \mathrm{mM} \mathrm{NaCl}$.

\section{Protocol 35: Modified Affymetrix small sample amplification (Steve Von Stetina, Rebecca Fox, and David Miller)}

Affymetrix hybridizations require 10-15 ug of labeled probe. Because RNA in this amount is rarely available from FACS isolated cells, we amplify initial RNA preparations with two rounds of a T7 RNA polymerase-dependent amplification protocol. The following bench protocol produces high-quality cRNA from 100 ng of total RNA. This protocol is a modified version of an amplification strategy originally described by Affymetrix (GeneChip Eukaryotic Small Sample Target Labeling Technical Note, Part 701129 Rev 1).

\section{Significant changes include:}


- $6 \mathrm{hr}$ for the RNA transcription step provides higher yields.

- For cRNA cleanup, $40 \%$ EtOH and two passes through the column dramatically enhanced yields.

\section{Other important points:}

- The protocol can be divided into two long days or four shorter days; in all, the protocol takes $\sim 24$ hours to complete.

- We obtain 30-70 ug of labeled cRNA from 100 ng total RNA after two rounds of amplification.

- The commercially available fragmentation buffer was more reliable than "home-brewed" solutions. The reasons for this difference are unknown.

- It is important to assess the quality and size distribution of amplified cRNA and subsequent fragmented cRNA label by gel electrophoresis (Agilent Bioanalyzer).

\section{MATERIALS}

\begin{tabular}{|c|c|c|}
\hline Reagent Name & Vendor & Catalog \# \\
\hline $\begin{array}{l}\text { T7-(dT) } \text { 24 }_{24} \text { primer, 2-step HPLC, } \\
\text { } \text { '-GGCDIOF } \\
\text { TACAGTGAATTGTAA- } \\
\text { TACGCTCACT } \\
\text { ATAGGGAGGCGG-(dT) })_{24}-3^{\prime}\end{array}$ & Operon (Qiagen) & \\
\hline $\begin{array}{l}\text { Superscript II, } 200 \mathrm{U} / \mathrm{ul} 40,000 \mathrm{U} \\
5 \mathrm{X} \text { first strand buffer, DTT included }\end{array}$ & Invitrogen & $18064-071$ \\
\hline $5 \mathrm{X}$ second strand buffer, $500 \mathrm{ul}$ & Invitrogen & $10812-014$ \\
\hline $\begin{array}{l}\text { E. coli DNA Polymerase, } 10 \mathrm{U} / \mathrm{ul} \text {, } \\
1000 \mathrm{U}\end{array}$ & Invitrogen & $18010-025$ \\
\hline E. coli DNA Ligase, $10 \mathrm{U} / \mathrm{ul}, 100 \mathrm{U}$ & Invitrogen & $18052-019$ \\
\hline RNase H, 2 U/ul, $120 \mathrm{U}$ & Invitrogen & 18021-071 \\
\hline T4 DNA Polymerase, 5 U/ul, $250 \mathrm{U}$ & Invitrogen & $18005-025$ \\
\hline Random Primers & Invitrogen & $48190-011$ \\
\hline dNTP mix, $100 \mathrm{mM}$ each & NEB & N0446S \\
\hline rRNasin, $40 \mathrm{U} / \mathrm{ul}$ 10,000 U & Promega & $\mathrm{N} 2515$ \\
\hline Glycogen, $5 \mathrm{mg} / \mathrm{ml}, 5 \mathrm{ml}$ & Ambion & 9510 \\
\hline Ammonium Acetate, $7.5 \mathrm{M}, 100 \mathrm{ml}$ & Sigma & A-2706 \\
\hline MEGAscript T7 kit & Ambion & 1334 \\
\hline $\begin{array}{l}\text { Affymetrix GeneChip Sample } \\
\text { Cleanup Module }\end{array}$ & Affymetrix & 900371 \\
\hline$\beta$ - mercaptoethanol, $25 \mathrm{ml}$ & Sigma & M-3148 \\
\hline $\begin{array}{l}\text { Enzo BioArray HighYield RNA } \\
\text { Transcript Labeling kit, } 10 \text { reactions }\end{array}$ & Affymetrix & 900182 \\
\hline
\end{tabular}

\section{Solutions (USE DEPC-H 2 O FOR ALL SOLUTIONS):}


DEPC-H O: Fill 4L Flask in RNase-free cabinet with 3.5L of Milli-Q water. In hood, add $3.5 \mathrm{ml}$ DEPC (final concentration is $0.1 \%$ ). Leave stirring at RT o/n. Autoclave the following day.

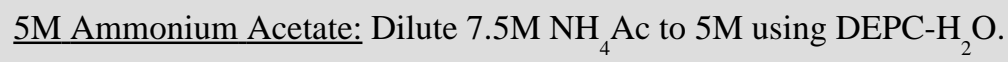

Random Primers: Dilute $3 \mathrm{ug} / \mathrm{ul}$ stock to $1 \mathrm{ug} / \mathrm{ul}$ using DEPC- $\mathrm{H}_{2} \mathrm{O}$; store in $5 \mathrm{ul}$ aliquots at $-20^{\circ} \mathrm{C}$.

$10 \mathrm{mM}$ dNTP mix: Mix $100 \mathrm{ul}$ of each dNTP with $600 \mathrm{ul} \mathrm{DEPC-H_{2 }}$ O. Store in $5 \mathrm{ul}$ aliquots at $-20^{\circ} \mathrm{C}$.

\section{METHODS}

First Amplification Cycle (can split into 2 days if desired)

Step 1. First cycle, first strand cDNA synthesis

1. Combine100 ng total RNA and the following components in a $1.5 \mathrm{ml}$ RNase free microfuge tube.

\begin{tabular}{|c|c|c|}
\hline & Volume/reaction & Concentration \\
\hline DEPC-H $_{2} \mathbf{O}$ & $9 \mathrm{ul}$ & $100 \mathrm{ng} / \mathrm{ul}$ \\
\hline Total RNA & $1 \mathrm{ul}$ & $100 \mathrm{ng} / \mathrm{ul}$ \\
\hline T7-(dT) (24 $_{\text {primer }}$ & $1 \mathrm{ul}$ & \\
\hline total volume & $11 \mathrm{ul}$ & \\
\hline
\end{tabular}

2. Vortex tube then quick spin in small benchtop microfuge (picofuge).

3. Place tube in $70^{\circ} \mathrm{C}$ heat block for $10 \mathrm{~min}$.

4. Chill on ice for $2 \mathrm{~min}$.

5. Add the following reagents to microfuge tube:

\begin{tabular}{|c|c|}
\hline & Volume/reaction \\
\hline (RNA/primer mixture) & $(11 \mathrm{ul})$ \\
\hline 5X first strand buffer & $4 \mathrm{ul}$ \\
\hline DTT, 0.1M & $2 \mathrm{ul}$ \\
\hline dNTP mix, 10 mM & $1 \mathrm{ul}$ \\
\hline RNasin, 40 U/ul & $1 \mathrm{ul}$ \\
\hline total volume & $19 \mathrm{ul}$ \\
\hline
\end{tabular}

6. Vortex, spin. Incubate in $42^{\circ} \mathrm{C}$ water bath for $2 \mathrm{~min}$.

Add $1 \mathrm{ul}$ of Superscript II (200 U/ul) to the preheated reaction, vortex and quick spin.

Incubate at $42^{\circ} \mathrm{C}$ for 1 hour.

\section{Step 2. First Cycle, second strand cDNA synthesis}

1. Spin down first strand reaction, then cool on ice for $2 \mathrm{~min}$. 
2. Transfer solution to a $0.5 \mathrm{ml}$ RNase-free microfuge tube.

3. Add following reagents to the first strand synthesis reaction:

\begin{tabular}{|c|c|}
\hline & Volume/reaction \\
\hline (First strand synthesis reaction) & $(20 \mathrm{ul})$ \\
\hline DEPC-H $_{2} \mathbf{O}$ & $91 \mathrm{ul}$ \\
\hline $\mathbf{5 X}$ second strand buffer & $30 \mathrm{ul}$ \\
\hline dNTP mix & $3 \mathrm{ul}$ \\
\hline E.coli DNA ligase & $1 \mathrm{ul}$ \\
\hline E. coli DNA polymerase & $4 \mathrm{ul}$ \\
\hline RNase $\mathbf{H}$ & $1 \mathrm{ul}$ \\
\hline total volume & $150 \mathrm{ul}$ \\
\hline
\end{tabular}

4. Vortex, spin. Incubate at $16^{\circ} \mathrm{C}$ in a PCR machine for $2 \mathrm{hr}$.

5. Add 2 ul of T4 DNA polymerase to the reaction and incubate for an additional $15 \mathrm{~min}$ at $16^{\circ} \mathrm{C}$. (this step polishes the ends of the dsDNA)

\section{Step 3. First cycle, double-stranded cDNA clean-up by ethanol precipitation.}

1. Following second strand synthesis, transfer contents of $0.5 \mathrm{ml}$ microfuge into a $1.5 \mathrm{ml}$ RNase-free microfuge tube.

2. Add following to tube (all items stored in RNase-free freezer):

\begin{tabular}{|c|c|}
\hline Reagent & Volume/reaction \\
\hline $5 \mathrm{mg} / \mathrm{ml}$ glycogen & $1 \mathrm{ul}$ \\
\hline $5 \mathrm{M} \mathrm{NH}_{4} \mathrm{OAc}$ & 92 ul (0.6 volume) \\
\hline Ice cold absolute EtOH & $612 \mathrm{ul}$ (2.5 volumes) \\
\hline
\end{tabular}

3. Mix by inversion. Centrifuge for $20 \mathrm{~min}$ at $4{ }^{\circ} \mathrm{C}$ at $14000 \mathrm{rpm}$. **You should see a pellet!**

4. REMOVE ETHANOL BY ASPIRATION USING RNase-free ROUND GEL-LOADING TIPS (Marsh Biomedical Products, Inc \#T-3000).

5. Wash with $70 \%$ cold ethanol (stored in freezer); spin for $14,000 \mathrm{rpm}$ in microfuge for $5 \mathrm{~min}$ at $4{ }^{\circ} \mathrm{C}$.

6. Remove ethanol as above. Speed-vac for 5 min to dry pellet.

THIS IS A POTENTIAL STOPPING POINT. STORE PELLET AT $-20^{\circ} \mathrm{C}$ IF NOT CONTINUING ON TO IVT REACTION.

\section{Step 4. First cycle, in vitro transcription (IVT) for cRNA using Ambion MEGAscript T7 kit}

1. Resuspend cDNA pellet in 8 ul DEPC- $\mathrm{H}_{2} \mathrm{O}$. Vortex and pipet up and down to resuspend pellet.

2. Add the following (can make master mix): 


\begin{tabular}{|c|c|}
\hline & Volume/reaction \\
\hline (cDNA) & $(8 \mathrm{ul})$ \\
\hline dNTP mix & $8 \mathrm{ul}$ \\
\hline 10X reaction buffer & $2 \mathrm{ul}$ \\
\hline Ambion enzyme mix & $2 \mathrm{ul}$ \\
\hline total volume & $20 \mathrm{ul}$ \\
\hline
\end{tabular}

Vortex, spin. Incubate in $37^{\circ} \mathrm{C}$ water bath for 6 hours.

\section{Step 5. First cycle, cRNA clean-up with Affy Cleanup Kit}

****Add 10 ul $\beta$-ME to every 1 ml IVT cRNA Binding Buffer before starting clean-up*****

1. Add $80 \mathrm{ul}$ DEPC $-\mathrm{H}_{2} \mathrm{O}$ to IVT reaction (total volume $=100 \mathrm{ul}$ )

2. Add 350 ul IVT cRNA Binding Buffer; mix. Add 300 ul 100\% EtOH. Mix by pipeting.

3. Add sample (750 ul) to a supplied mini-column. Pulse in microfuge for $15 \mathrm{sec}$.

4. Pipet flow-through from collection tube and pulse through mini-column again.

5. Discard collection tube. Transfer column to a new $2.0 \mathrm{ml}$ collection tube.

6. Add 500 ul IVT cRNA Wash Buffer. Pulse in microfuge for $15 \mathrm{sec}$. Discard flow-through.

7. Add 500 ul $80 \%$ EtOH. Spin for 2 min in microfuge at full speed. Discard collection tube.

8. Transfer column to a kit-supplied $1.5 \mathrm{ml}$ collection tube.

9. Add $32 \mathrm{ul}$ DEPC- $\mathrm{H}_{2} \mathrm{O}$ to mini-column. Incubate at RT for $1 \mathrm{~min}$. Spin for $1 \mathrm{~min}$ at full-speed.

10. Determine concentration of cRNA using spectrophotometer.

a. Add 2 ul cRNA to 98 ul DEPC- $\mathrm{H}_{2} \mathrm{O}$ (1:50 dilution).

b. Use lab spec (DNA/RNA calculator) to determine A260.

1. Determine concentration using conversion factor of $40 \mathrm{ug} / \mathrm{ml}$ (for RNA).

2. If the concentration is less than $10 \mathrm{ng} / \mathrm{ul}$, speed-vac to reduce volume of cRNA from $30 \mathrm{ul}$ to $10 \mathrm{ul}$ (DO NOT DRY ALL THE WAY!) and use all the cRNA for $2^{\text {nd }}$ round.

3. If the concentration is greater than $10 \mathrm{ng} / \mathrm{ul}$, use $100 \mathrm{ng}$ for next step.

11. Store cRNA at $-80^{\circ} \mathrm{Co}$ on.

\section{Second Amplification Cycle}

\section{Step 6. Second Cycle, first strand cDNA synthesis}

1. Start with $100 \mathrm{ng}$ of first round cRNA (if you have less, use all of your first round sample).

2. Mix the following in an RNase-free $1.5 \mathrm{ml}$ microfuge tube: 


\begin{tabular}{|c|c|}
\hline & Volume/reaction \\
\hline 100 ng cRNA & up to $10 \mathrm{ul}$ \\
\hline Random primers, $\mathbf{1}$ ug/ul & $1 \mathrm{ul}$ \\
\hline DEPC-H $\mathbf{O}$ & Add to final volume of $11 \mathrm{ul}$ \\
\hline total volume & $11 \mathrm{ul}$ \\
\hline
\end{tabular}

3. Vortex and spin.

4. Incubate in $70^{\circ} \mathrm{C}$ heat block for $10 \mathrm{~min}$ (to denature).

5. Cool on ice for $2 \mathrm{~min}$.

6. Add the following to the tube for first strand synthesis (make master mix if more than 1 sample):

\begin{tabular}{|c|c|}
\hline & Volume/reaction \\
\hline (cRNA/primer mixture) & $(11 \mathrm{ul})$ \\
\hline 5X first strand buffer & $4 \mathrm{ul}$ \\
\hline DTT, 0.1 M & $2 \mathrm{ul}$ \\
\hline dNTP mix, 10 mM & $1 \mathrm{ul}$ \\
\hline RNasin & $1 \mathrm{ul}$ \\
\hline total volume & $19 \mathrm{ul}$ \\
\hline
\end{tabular}

7. Incubate in $42^{\circ} \mathrm{C}$ water bath for $2 \mathrm{~min}$

8. Add 1 ul SuperScript II. Vortex, spin.

9. Incubate at $42^{\circ} \mathrm{C}$ for 1 hour.

10. Add 1 ul RNase H.

11. Incubate in $37{ }^{\circ} \mathrm{C}$ water bath for $20 \mathrm{~min}$, then incubate in $95^{\circ} \mathrm{C}$ heat block for $5 \mathrm{~min}$,

\section{Step 7. Second cycle, second strand cDNA synthesis with T7-(dT) ${ }_{24}$ primer}

1. Spin down first strand reaction, then add $1 \mathrm{ul} \mathrm{T7}-(\mathrm{dT})_{24}$ primer.

2. Incubate in $70^{\circ} \mathrm{C}$ heat block for 10 minutes, then cool on ice.

3. Transfer solution to a $0.5 \mathrm{ml}$ RNase-free microfuge tube.

4. Add the following reagents to the mix (make master mix if more than 1 sample)

\begin{tabular}{|c|c|}
\hline & Volume/reaction \\
\hline (First strand mix/T7-(dT) $\left.{ }_{\mathbf{2 4}}\right)^{-}$ & $(22 \mathrm{ul})$ \\
\hline DEPC-H $\mathbf{O}$ & $91 \mathrm{ul}$ \\
\hline $\mathbf{5 X}$ second strand buffer & $30 \mathrm{ul}$ \\
\hline dNTP mix, $\mathbf{1 0} \mathbf{~ m M}$ & $3 \mathrm{ul}$ \\
\hline
\end{tabular}




\begin{tabular}{|c|c|}
\hline & Volume/reaction \\
\hline E. coli DNA Polymerase & $4 \mathrm{ul}$ \\
\hline total volume & $150 \mathrm{ul}$ \\
\hline
\end{tabular}

5. Vortex, spin. Incubate at $16^{\circ} \mathrm{C}$ in a PCR machine for $2 \mathrm{hr}$.

6. Add $2 \mathrm{ul}$ of T4 DNA polymerase to the reaction and incubate for an additional $15 \mathrm{~min}$ at $16^{\circ} \mathrm{C}$.

Step 8. Second cycle, double-stranded cDNA clean-up by ethanol precipitation.

1. Following second strand synthesis, transfer contents of $0.5 \mathrm{ml}$ microfuge to $1.5 \mathrm{ml}$ RNase-free microfuge tube.

2. Add following to tube (all items stored in RNase-free freezer):

\begin{tabular}{|c|c|}
\hline & Volume/reaction \\
\hline $\mathbf{5} \mathbf{~ m g / m l ~ g l y c o g e n ~}$ & $1 \mathrm{ul}$ \\
\hline $\mathbf{5} \mathbf{M ~ N H} \mathbf{O} \mathbf{O A c}$ & $92 \mathrm{ul}(0.6$ volume $)$ \\
\hline Ice cold absolute $\mathbf{E t O H}$ & $612 \mathrm{ul}(2.5$ volumes $)$ \\
\hline
\end{tabular}

3. Mix by inversion. Centrifuge for $20 \mathrm{~min}$ at $4^{\circ} \mathrm{C}$ at $14000 \mathrm{rpm}$. **You should have a pellet!**

4. REMOVE ETHANOL BY ASPIRATION USING RNase-free ROUND GEL-LOADING TIPS.

5. Wash with $70 \%$ cold ethanol (stored in freezer); spin for $14,000 \mathrm{rpm}$ for $5 \mathrm{~min}$ at $4^{\circ} \mathrm{C}$.

6. Remove ethanol as above. Speed-vac for $5 \mathrm{~min}$ to dry pellet.

THIS IS A POTENTIAL STOPPING POINT. STORE PELLET AT $-20^{\circ} \mathrm{C}$ IF NOT CONTINUING ON TO IVT-LABELING REACTION.

Step 9. Second cycle, IVT for cRNA amplification and labeling with Enzo kit.

1. Resuspend pellet in 22 ul DEPC- $\mathrm{H}_{2} \mathrm{O}$. Vortex and pipet up and down to resuspend pellet.

2. Add the following to the resuspended pellet: DO NOT MAKE MASTER MIX!

\begin{tabular}{|c|c|}
\hline & Volume/reaction \\
\hline (cDNA) & $(22 \mathrm{ul})$ \\
\hline 10X HY reaction buffer (tube 1) & $4 \mathrm{ul}$ \\
\hline 10X Biotin labeled ribonucleotides (tube 2) & $4 \mathrm{ul}$ \\
\hline 10X DTT (tube 3) & $4 \mathrm{ul}$ \\
\hline 10X RNase inhibitor mix (tube 4) & $4 \mathrm{ul}$ \\
\hline 20X T7 RNA Polymerase & $2 \mathrm{ul}$ \\
\hline total volume & $40 \mathrm{ul}$ \\
\hline
\end{tabular}

3. Incubate reaction in $37^{\circ} \mathrm{C}$ water bath for 6 hours. 


\section{Step 10. Second cycle, labeled cRNA target clean-up with Affy Cleanup Kit.}

*****Add 10 ul $\beta$-ME to every $1 \mathrm{ml}$ IVT cRNA Binding Buffer before starting clean-up*****

1. Add $60 \mathrm{ul}$ DEPC- $\mathrm{H}_{2} \mathrm{O}$ to IVT reaction (total volume $=100 \mathrm{ul}$ )

2. Add 350 ul IVT cRNA Binding Buffer; mix. Add 300 ul 100\% EtOH. Mix by pipeting.

3. Add sample (750 ul) to a supplied mini-column. Pulse in microfuge for $15 \mathrm{sec}$.

4. Pipet flow-through from collection tube and pulse through mini-column again.

5. Discard collection tube. Transfer column to a new $2.0 \mathrm{ml}$ collection tube.

6. Add 500 ul IVT cRNA Wash Buffer (to wash). Pulse in microfuge for $15 \mathrm{sec}$. Discard flow-through.

7. Add $500 \mathrm{ul} 80 \% \mathrm{EtOH}$. Spin for $2 \mathrm{~min}$ in microfuge at full speed. Discard collection tube.

8. Transfer column to a supplied $1.5 \mathrm{ml}$ collection tube.

9. Add $32 \mathrm{ul} \mathrm{DEPC- \textrm {H } _ { 2 }} \mathrm{O}$ to mini-column. Incubate at RT for $1 \mathrm{~min}$. Spin for $1 \mathrm{~min}$ at full-speed.

10. Keep eluate, discard column.

\section{Step 11. Determine concentration, remove aliquots for bioanalysis, fragment labeled cRNA.}

1. Add 2 ul cRNA to 98 ul DEPC- $\mathrm{H}_{2} \mathrm{O}$ (1:50 dilution).

2. Use lab spec (DNA/RNA calculator) to determine A260. cRNA should be 0.5-3 ug/ul.

3. Dilute a portion of labeled cRNA to $100 \mathrm{ng} / \mathrm{ul}$. Remove $3 \mathrm{ul}$ for for gel electrophoresis (Agilent Bioanalyzer)

Fragment RNA in $10-15$ ug aliquots.

\begin{tabular}{|c|c|c|}
\hline & $\mathbf{1 0}$ ug & $\mathbf{1 5}$ ug \\
\hline cRNA & Variable amount $(\leq$ than $12 \mathrm{ul})$ & Variable amount $(\leq$ than $22 \mathrm{ul})$ \\
\hline $\begin{array}{c}\text { 5X Fragmentation buffer } \\
\text { (Affymetrix) }\end{array}$ & $4 \mathrm{ul}$ & $6 \mathrm{ul}$ \\
\hline DEPC-H $_{2} \mathbf{O}$ & up to $20 \mathrm{ul}$ & up to $30 \mathrm{ul}$ \\
\hline total volume & $20 \mathrm{ul}$ & $30 \mathrm{ul}$ \\
\hline
\end{tabular}

4. Incubate at $95^{\circ} \mathrm{C}$ for $35 \mathrm{~min}$.

5. Place on ice following incubation.

6. Analyze unfragmented and fragmented samples on Bioanalyzer. If samples look good (Figure 22), you may apply to a C. elegans Affy chip. 


\section{A}

\section{Prefragmented}

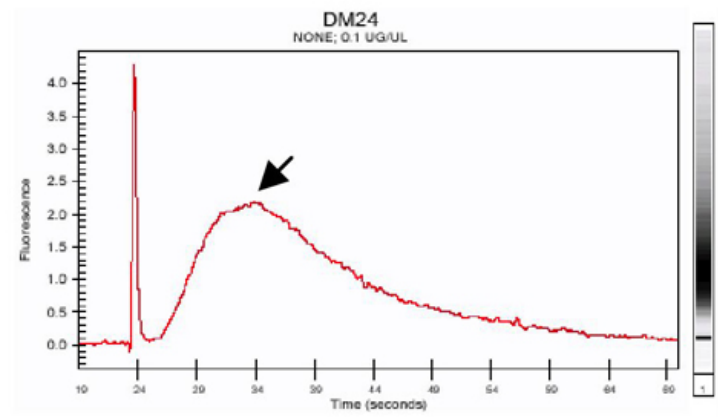

\section{Prefragmented}

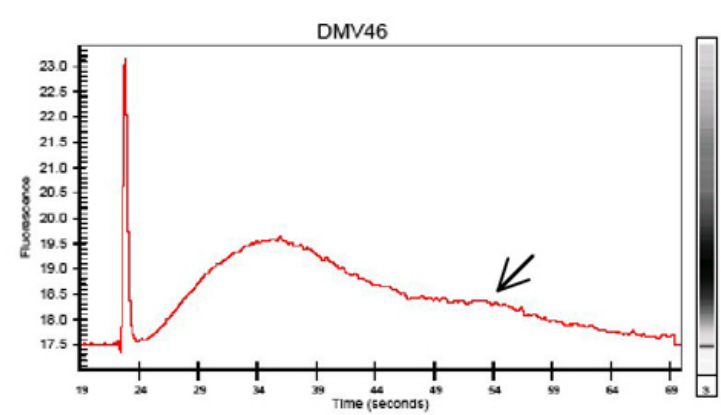

Fragmented

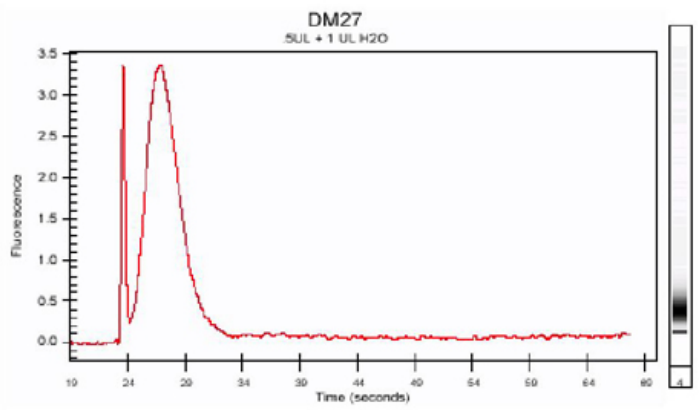

Fragmented

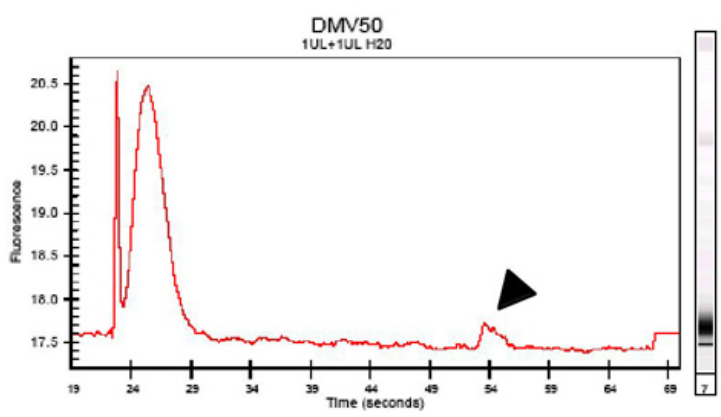

Figure 22. Assessing quality of RNA amplified from cultured cells for gene array hybridization. A. The prefragmented RNA should show a broad size distribution (X-axis). Smaller fragments should be more abundant (Y-axis, arrow), as the amplification process is biased to the 3' end. The gel image should be a large smear, with no intense high molecular weight products. Fragmented RNA should be 200 bp or less. B. These plots demonstrate a sample that is not hybridizable. The prefragmented RNA distribution includes a long tail indicative of non-template dependent high molecular weight products (open arrow). The presence of unfragmented peaks are evident (arrowhead). For patterns like this, we either repeat the amplification/fragmentation or discard that RNA sample (Steve Von Stetina, Rebecca Fox, and David Miller).

7. Alternatively, you may store amplified and fragmented RNA samples at $-80^{\circ} \mathrm{C}$ for hybridization at a later time.

\section{Protocol 36: RNA interference in cultured embryonic cells (Kevin Strange and Rebecca Morrison)}

1. $\quad$ dsRNA is synthesized and purified using well established protocols.

2. Equal numbers of cells from a cell isolate are plated in either control L-15 cell culture medium or L-15 medium containing $15 \mu \mathrm{g} / \mathrm{ml}$ dsRNA.

3. Two to three hours after plating, the dsRNA is diluted to a final concentration of $5 \mu \mathrm{g} / \mathrm{ml}$ using L-15 culture medium. The time course for gene expression knockdown is dependent on the half-life of the protein encoded by the targeted gene and on the cell type in which it is expressed (Christensen et al., 2002). 


\section{References}

Aballay, A., and Ausubel, F. M. (2001). Programmed cell death mediated by ced-3 and ced-4 protects Caenorhabditis elegans from Salmonella typhimurium-mediated killing. Proc. Natl. Acad. Sci. USA 98, $2735-2739$. Abstract Article

Brenner, S. (1974). The genetics of Caenorhabditis elegans. Genetics 77, 71-94. Abstract

Chalfie, M., Tu, Y., Euskirchen, G., Ward, W.W., and Prasher, D.C. (1994). Green fluorescent protein as a marker for gene expression. Science 263, 802-805. Abstract

Christensen, M., Estevez, A., Yin, X., Fox, R., Morrison, R., McDonnell, M., Gleason, C., Miller, D.M., 3rd, and Strange, K. (2002). A primary culture system for functional analysis of $C$. elegans neurons and muscle cells. Neuron 33, 503-514. Abstract Article

Collet, J., Spike, C.A., Lundquist, E.A., Shaw, J.E., and Herman, R.K. (1998). Analysis of osm-6, a gene that affects sensory cilium structure and sensory neuron function in Caenorhabditis elegans. Genetics 148, 187-200. Abstract

Costa, M., Draper, B.W., and Priess, J.R. (1997). The role of actin filaments in patterning the Caenorhabditis elegans cuticle. Dev. Biol. 184, 373-384. Abstract Article

Ellis, R.E., and Horvitz, H.R. (1991). Two C. elegans genes control the programmed deaths of specific cells in the pharynx. Development 112, 591-603. Abstract

Ellis, R.E., Jacobson, D.M., and Horvitz, H.R. (1991). Genes required for the engulfment of cell corpses during programmed cell death in Caenorhabditis elegans. Genetics 129, 79-94. Abstract

Ellis, R.E., Jacobson, D.M., and Horvitz, H.R. (1991). Genes Required for the Engulfment of Cell Corpses During Programmed Cell Death in Caenorhabditis elegans. Genetics 129, 79-94. Abstract

Fares, H., and Greenwald, I. (2001). Genetic analysis of endocytosis in Caenorhabditis elegans: coelomocyte uptake defective mutants. Genetics 159, 133-145. Abstract

Fire, A., Xu, S., Montgomery, M.K., Kostas, S.A., Driver, S.E., and Mello, C.C. (1998). Potent and specific genetic interference by double-stranded RNA in Caenorhabditis elegans. Nature 391, 806-811. Abstract Article

Fox, R.M., et al. (2005). A gene expression fingerprint of C. elegans embryonic motor neurons. BMC Genomics $6(1)$, p. 42.

Francis, R., Barton, M.K., Kimble, J., and Schedl, T. (1995). gld-1, a tumor suppressor gene required for oocyte development in Caenorhabditis elegans. Genetics 139, 579-606. Abstract

Gartner, A., Milstein, S., Ahmed, S., Hodgkin, J., and Hengartner, M.O. (2000). A conserved checkpoint pathway mediates DNA damage-induced apoptosis and cell cycle arrest in C. elegans. Mol. Cell 5, 435-443. Abstract Article

Gavrieli, Y., Sherman, Y., and Ben-Sasson, S.A. (1992). Identification of programmed cell death in situ via specific labeling of nuclear DNA fragmentation. J. Cell. Biol. 119, 493-501. Abstract Article

Grant, B., and Hirsh, D. (1999). Receptor-mediated endocytosis in the Caenorhabditis elegans oocyte. Mol. Biol. Cell 10,4311-4326. Abstract

Gumienny, T.L., Lambie, E., Hartwieg, E., Horvitz, H.R., and Hengartner, M.O. (1999). Genetic control of programmed cell death in the Caenorhabditis elegans hermaphrodite germline. Development 126, 1011-1022. Abstract

Hall, D.H. (1995). Electron microscopy and three-dimensional image reconstruction. Methods Cell Biol. 48, 395-436. Abstract 
Hedgecock, E.M., Culotti, J.G., Thomson, J.N., and Perkins, L.A. (1985). Axonal guidance mutants of Caenorhabditis elegans identified by filling sensory neurons with fluorescein dyes. Dev. Biol. 111, 158-170. Abstract Article

Helmchen, F., and Denk, W. (2002). New developments in multiphoton microscopy. Curr. Opin. Neurobiol. 12, 593-601. Abstract Article

Jorgensen, E.M., and Mango, S.E. (2002). The art and design of genetic screens: Caenorhabditis elegans. Nat. Rev. Genet. 3, 356-369. Abstract Article

Lettre, G., Kritikou, E.A., Jaeggi, M., Calixto, A., Fraser, A.G., Kamath, R.S., Ahringer, J., and Hengartner, M.O. (2004). Genome-wide RNAi identifies p53-dependent and -independent regulators of germ cell apoptosis in $C$. elegans. Cell Death Differ. Abstract Article

Michalet, X., Kapanidis, A.N., Laurence, T., Pinaud, F., Doose, S., Pflughoefft, M., and Weiss, S. (2003). The power and prospects of fluorescence microscopies and spectroscopies. Ann. Rev. Biophys. Biomol. Struct. 32, 161-182. Abstract Article

Miller, D.M., 3rd, Desai, N.S., Hardin, D.C., Piston, D.W., Patterson, G.H., Fleenor, J., Xu, S., and Fire, A. (1999). Two-color GFP expression system for C. elegans. Biotechniques 26, 914-918, 920-911. Abstract

Miyawaki, A. (2002). Green fluorescent protein-like proteins in reef Anthozoa animals. Cell Struct. Funct. 27, 343-347. Abstract Article

Nakano, A. (2002). Spinning-disk confocal microscopy - a cutting-edge tool for imaging of membrane traffic. Cell Struct. Funct. 27, 349-355. Abstract Article

Paupard, M.C., Miller, A., Grant, B., Hirsh, D., and Hall, D.H. (2001). Immuno-EM localization of GFP-tagged yolk proteins in C. elegans using microwave fixation. J. Histochem. Cytochem. 49, 949-956. Abstract

Perkins, L.A., Hedgecock, E.M., Thomson, J.N., and Culotti, J.G. (1986). Mutant sensory cilia in the nematode Caenorhabditis elegans. Dev. Biol. 117, 456-487. Abstract Article

Shaham, S., and Bargmann, C.I. (2002). Control of neuronal subtype identity by the C. elegans ARID protein CFI-1. Genes Dev. 16, 972-983. Abstract Article

Strome, S. (1986). Fluorescence visualization of the distribution of microfilaments in gonads and early embryos of the nematode Caenorhabditis elegans. J. Cell. Biol. 103, 2241-2252. Abstract Article

Sulston, J.E., and Horvitz, H.R. (1977). Post-embryonic cell lineages of the nematode, Caenorhabditis elegans. Dev. Biol. 56, 110-156. Abstract Article

Sulston, J.E., Schierenberg, E., White, J.G., and Thomson, J.N. (1983). The embryonic cell lineage of the nematode Caenorhabditis elegans. Dev. Biol. 100, 64-119. Abstract Article

Sulston, J.E., Schierenberg, E., White, J.G., and Thomson, J.N. (1983). The Embryonic Cell Lineage of the Nematode Caenorhabditis elegans. Dev. Biol. 100, 64-119. Abstract Article

Thellmann, M., Hatzold, J., and Conradt, B. (2003). The Snail-like CES-1 protein of C. elegans can block the expression of the BH3-only cell-death activator gene egl-1 by antagonizing the function of bHLH proteins. Development 130, 4057-4071. Abstract Article

Timmons, L., and Fire, A. (1998). Specific interference by ingested dsRNA. Nature 395, 854. Abstract Article

Wallace, W., Schaefer, L.H., and Swedlow, J.R. (2001). A workingperson's guide to deconvolution in light microscopy. Biotechniques 31, 1076-1078, 1080, 1082 passim. Abstract

Wu, Y.C., Stanfield, G.M., and Horvitz, H.R. (2000). NUC-1, a Caenorhabditis elegans DNase II homolog, functions in an intermediate step of DNA degradation during apoptosis. Genes Dev. 14, 536-548. Abstract 
Yang, T.T., Kain, S.R., Kitts, P., Kondepudi, A., Yang, M.M., and Youvan, D.C. (1996). Dual color microscopic imagery of cells expressing the green fluorescent protein and a red-shifted variant. Gene 173, 19-23. Abstract Article

Zhang, J., Campbell, R.E., Ting, A.Y., and Tsien, R.Y. (2002). Creating new fluorescent probes for cell biology. Nat. Rev. Mol. Cell. Biol. 3, 906-918. Abstract Article

Zhang, S., Ma, C., and Chalfie, M. (2004). Combinatorial marking of cells and organelles with reconstituted fluorescent proteins. Cell 119, 137-144. Abstract Article

Zhang, Y., Ma, C., Delohery, T., Nasipak, B., Foat, B.C., Bounoutas, A., Bussemaker, H.J., Kim, S.K., and Chalfie, M. (2002). Identification of genes expressed in C. elegans touch receptor neurons. Nature 418, 331-335. Abstract Article

Zhou, Z., Hartwieg, E., and Horvitz, H.R. (2001). CED-1 is a transmembrane receptor that mediates cell corpse engulfment in C. elegans. Cell 104, 43-56. Abstract Article

All WormBook content, except where otherwise noted, is licensed under a Creative Commons Attribution License. 